\title{
General Purpose Reloadable Prepaid Cards: Penetration, Use, Fees and Fraud Risks
}

\author{
Fumiko Hayashi and Emily Cuddy \\ Federal Reserve Bank of Kansas City ${ }^{*}$
}

October 2013

\begin{abstract}
Prepaid cards are the most rapidly growing payment instrument. General purpose reloadable (GPR) prepaid cards, in particular, have gained considerable traction among consumers who lack access to other electronic payment methods, such as debit and credit cards. This study examines the end-user experience of having a GPR card. It investigates which factors, if any, affect the intensity and duration of GPR card use, estimates the fee burden associated with various card usage patterns, and calculates fraud rates by transaction and merchant type. Because we lack cardholder information other than zip code, we supplement our card data with local demographic and socioeconomic data to test whether these factors are correlated with the observed variation in card use and incurred fees. Our results suggest that both account and cardholder characteristics significantly influence the life span, the load and debit activities, the shares of purchase and cash withdrawals, and the average number and value of fees incurred per month, and that transaction and merchant types influence the rate of fraudulent transactions.
\end{abstract}

JEL Classification: D12; D14; E42; G21

Keywords: General purpose reloadable prepaid cards; Consumer payment behavior; Fraud risks; Payment card fees

\footnotetext{
* Payments System Research, Federal Reserve Bank of Kansas City. E-mail: fumiko.hayashi@kc.frb.org. The views expressed herein are those of the authors and do not necessarily reflect the views of the Federal Reserve Bank of Kansas City or the Federal Reserve System. The authors thank Neil Bhutta, Geoffrey Gerdes, and participants at the Federal Reserve System Applied Microeconomics Conference and the Federal Reserve System Payments Analyst Meeting for their valuable comments. The authors wish to acknowledge and thank NetSpend for generously providing the data used in this paper. Special thanks to Steve Martin and Stephanie Rae Green at NetSpend for their contributions to this paper.
} 


\section{Introduction}

In the United States, prepaid cards are the most rapidly growing payment instrument. According to the 2010 Federal Reserve Payments Study, the growth rate of prepaid cards was more than 20 percent between 2006 and 2009. The industry expects this high growth rate to continue (Aite Group).

Among various types of prepaid cards, general purpose reloadable (GPR) prepaid cards are gaining the most traction among consumers who do not have access to other forms of electronic payments, such as debit or credit cards, or prefer not to use them for certain transactions. GPR cards carry at least one of the major payment card network brands-American Express, Discover, MasterCard, Visa, or a PIN debit network—and can be used to make purchases at any merchant that accepts that card brand as well as to obtain cash at any ATM that connects to the networks. ${ }^{1}$ Cardholders must load value onto their cards before they use them for purchases or cash withdrawals, and they can reload value via electronic funds transfer or at a retail location that participates in a reload network.

GPR cards are the focus of this study. As these cards gain more popularity, policy issues surrounding these cards arise, such as how to protect cardholders from fraudulent transactions on the cards or how to protect cardholders' money if the card issuers go bankrupt. ${ }^{2}$ Financial institutions promote these cards not only to unbanked consumers but also to banked consumers since their revenues from debit cards were reduced by the recently implemented debit card

\footnotetext{
${ }^{1}$ Starting April 1, 2013, general-use prepaid cards must carry at least two unaffiliated network brands to comply with Regulation II, which sets rules on debit and prepaid card interchange fees and routing.

${ }^{2}$ Recently, the Consumer Financial Protection Bureau proposed potential new regulations for general purpose prepaid cards.
} 
regulation. ${ }^{3}$ Although research on consumer payments has been growing recently, most studies have analyzed consumers who hold checking accounts and use debit and credit cards. Little research has been conducted to explain payment behavior of consumers who do not access debit or credit cards in general and to explain how consumers use the GPR cards in particular.

Two exceptions are Rhine et al. (2007) and Wilshusen et al. (2012). The former examined the transactions of approximately 2000 cardholders who use general purpose prepaid cards. The authors randomly selected 500 cardholders from each of four prepaid card providers and collected those cardholders' monthly transaction data over a period of 12 months between 2005 and 2006. They provided detailed statistics on loads, purchase transactions, and cash withdrawals per month; however, they did not identify any sources of the observed variation in their findings.

Wilshusen et al. (2012) analyzed an anonymized dataset of more than 280 million transactions made on more than 3 million cards issued by Meta Payment Systems, a leading prepaid card issuer. These cards were issued in 15 prepaid card programs. Although their dataset includes transactions on cards issued over a six-year period of 2005-2010, most transactions occurred between 2009 and 2010. The study examined the life span of prepaid cards and the intensity of their use, including the number and value of spending, the composition of spending at merchants, cash withdrawals, and reloading of value onto cards, for four categories of prepaid card programs—-payroll cards, web-, retail-, and financial institution-distributed general purpose reloadable prepaid cards. The study also estimated revenues earned via various consumer fees and via interchange fees.

\footnotetext{
${ }^{3}$ Regulation II, implemented by the Federal Reserve Board in 2011, caps debit card interchange fees received by large financial institutions. Certain types of prepaid cards, such as reloadable prepaid cards, are exempt from this interchange fee cap.
} 
The purpose of our study is twofold. The first is to examine the end-user experience of using a GPR card. In this sense, we share a similar purpose with Rhine et al. (2007) and Wilshusen et al. (2012), although our study uniquely includes an assessment of the fraud risks associated with GPR card use. Our second purpose, however, is entirely novel in that we attempt to explain the observed variation in card use using account and local cardholder characteristics.

To address our research objectives, we analyze transactions on more than 3 million GPR cards managed by NetSpend over a one-year period from 2011 to 2012. We also incorporate zipcode level demographic and socioeconomic data to compensate for a lack of cardholder information—a common limitation of studies of consumer payment behavior. As such, our final datasets are significantly more detailed than those used by Rhine et al. (2007) and Wilshusen et al. (2012).

Questions we address include: How long do the card accounts typically survive? How often and in what amounts are accounts loaded by cardholders or by third parties such as the government? How often and in what amount are debit transactions made each month? What proportion of debit transactions are making purchases, withdrawing cash, paying bills, or transferring money between people? Where are purchase transactions made? What are the average number and value of fees incurred per month? How does prepaid card fraud typically occur? Which types of transactions have the highest fraud rates? Does ticket size vary between fraudulent and non-fraudulent transactions?

For the second part of our analysis, we conduct a regression analysis to quantify the effect of account and cardholder characteristics (such as reload status, fee program enrollment, age, household income, etc.) on card use. In particular, we examine their effect on the life span 
of cards, the intensity of card use, the proportion of purchase transactions and cash withdrawals, and the average number and value of incurred fees.

Our results suggest that account and local cardholder characteristics significantly influence card life span, load and debit activities, the shares of purchase transactions and cash withdrawals, and the average monthly fee burden. For example, the life span of cards is longer for accounts with direct deposits than for self-funded accounts or accounts that were never reloaded, which is consistent with Wilshusen et al. (2012). Our sample further reveals that the life span of cards for accounts with direct deposits by the government is longer than that for accounts with direct deposits by non-government entities. Our results also suggest including demographic characteristics for each zip code improves the model fit, although the improvement is not dramatic. This may imply that if we can use a finer unit for demographic characteristics (such as census tract instead of zip code), the model fit will improve further. It is difficult for prepaid card issuers to obtain their customers' detailed demographic characteristics, but many issuers are likely to collect their customers' street address, which can be easily converted to census tract.

The paper is organized as follows. Section 2 describes the data used in this paper. Section 3 presents penetration rates of GPR prepaid cards provided by NetSpend and investigates whether county level characteristics affect penetration rates. Section 4 provides a detailed examination of prepaid card use. Subsection 4.1 examines the life span by calculating survival rate and conducting a survival rate analysis using a hazards model. Subsection 4.2 reports the average numbers and values of loading and debit activities per month and undertakes a regression analysis to quantify what factors influence the intensity of debit activities. Subsection 4.3 examines the shares of purchase transactions and cash withdrawals. The composition of 
purchase transactions is reported in Subsection 4.4. The fees incurred by account holders are discussed in Section 5. Section 6 calculates fraud rates by transaction type, by fraud type (such as counterfeit, lost and stolen, account take over, or unauthorized), and by merchant category. Section 7 concludes.

\section{Data}

\subsection{NetSpend Data}

The analysis in this paper is based on data provided by NetSpend, which is a leading program manager in the prepaid card industry. While GPR prepaid cards are issued by depository institutions, program managers are those who are contractually charged with managing the programs on behalf of the depository institutions, i.e., the program manager must consult with and obtain approval from the institutions with respect to the design and fees associated with the card programs. Program managers also support card issuance, delivery and distribution, and —in some cases—are responsible for providing customer service. Although NetSpend-branded cards are issued by several financial institutions, the program manager provides centralized services for all cardholders, e.g., maintenance of the database containing cardholder account and transaction histories, approving and declining transactions, etc.

For this study, we use three datasets furnished by NetSpend. The first dataset contains all GPR prepaid accounts that were active over the one year period between July 1, 2011 and June 30, 2012. An active account is defined as an account that made at least one debit transaction during the one-year timeframe. NetSpend makes four types of debit transactions available for their account holders. They are (i) purchase transactions, (ii) cash withdrawal transactions, (iii) bill payments, and (iv) person-to-person transactions between NetSpend cardholders. More than three million accounts are included in the dataset. 
This dataset is a rich source of account information. First, it includes important dates, such as the account creation date and the last date a debit transaction was made. Second, it contains information about program types, such as enrollment in a monthly purchase fee program or a per-transaction fee program, and types of card distributor (e.g., check casher, retail, tax refunds, etc.). A third set of information is how the funds to the account were loaded (e.g., whether the account was ever reloaded, periodically vs. occasionally reloaded, and self-funded vs. direct deposits by third parties) and the total number and value of loads over the life of the account. A fourth set of information is aggregate transaction information, such as the total number and value of each of the four types of debit transactions and the number of overdraft transactions over the life of the account. A fifth set of information are the average number and value of fees paid by each account holder per month, which we supplement with more detailed account-level fee information from another dataset. Finally, we have very limited information about the account holder. All we observe is the zip code; whether alert services were utilized; and whether emails, customer service calls, or the NetSpend website was used to communicate with NetSpend.

The information in the first dataset is used to analyze the penetration rate of NetSpend cards by county in Section 3. It is also used to examine the factors that affect the length of the life of accounts and the use of cards, such as the frequency of debit transactions and the shares of four types of debit transactions, in Section 4. Each account holder's fees are analyzed in Section 5.

The second dataset contains all purchase and cash withdrawal transactions made with NetSpend cards during June 2012. Each transaction includes detailed transaction information, such as whether the transaction was a purchase transaction or cash withdrawal, whether the 
cardholder authorized the transaction by PIN or signature, whether the transaction was "card present (CP)" or "card not present (CNP)", ${ }^{4}$ and in which merchant category the transaction was made. This dataset is used in Section 4 to explore where NetSpend cardholders transact.

The third dataset includes all fraudulent and disputed transactions NetSpend has encountered. Each of those transactions has detailed information, such as the date of the transaction, transaction type, authorization method, merchant category, and transaction amount. We select fraudulent transactions which occurred during June 2012 and calculate fraud rates for various transaction types and merchant categories in Section 6.

Summary statistics of account characteristics in the first dataset are shown in Table 2.1. Accounts are divided into five groups, according to load type. The share of accounts that were never reloaded is about 18 percent. The rest of the accounts were reloaded at least once, and they are divided based on whether they were reloaded occasionally or periodically. The share of accounts that were occasionally reloaded is 13 percent. Among accounts that were periodically reloaded, they are divided based on whether reloads were self-funded, directly deposited by the government, or directly deposited by non-government entities. The share of accounts that were self-funded is the largest— 46 percent. The share of accounts with government direct deposits is 7 percent, and the share of accounts with non-government direct deposits is 19 percent.

There are two main types of purchase transaction fee programs. One is the per transaction fee program which assesses a per transaction fee for each purchase transaction. In our sample, more than three-quarters of accounts belong to the per-transaction fee program. The other is a monthly purchase fee program, which assesses a fixed monthly fee in place of a per transaction

\footnotetext{
${ }^{4} \mathrm{CP}$ transactions are typically made at physical locations, while CNP transactions are made over the Internet, by telephone, or by mail.
} 
fee. NetSpend currently offers two monthly purchase fee programs. ${ }^{5}$ The default monthly fee program charges $\$ 9.95$ per month. This fee is discounted to $\$ 4.95$ per month for account holders who have met a direct deposit threshold: 23 percent of accounts in our sample fall into one of these programs. ${ }^{6}$ Other fees assessed for non-purchase transactions or services utilized, such as ATM withdrawal fees and balance inquiry fees, are common across all the programs.

Accounts are also grouped by distributor type. The majority of accounts (60 percent) were distributed by check cashers. More than 20 percent of accounts were directly distributed by NetSpend. The rests were distributed by retail stores (10 percent), through disbursement (6 percent), by tax preparers (0.7 percent), or by others (1.1 percent).

NetSpend account holders can utilize several services offered. Alert services were utilized by 49 percent of accounts. To communicate with NetSpend about account balance and transaction inquiries or initiations, account holders can utilize email, customer service call, or the NetSpend website. More than 50 percent of account holders utilize these services (email - 58 percent; customer service call - 93 percent; and web - 61 percent).

Finally, we can observe whether account holders have ever made overdraft transactions. ${ }^{7}$ About 5 percent of accounts in our sample have made at least one overdraft transaction. Some accounts are also offered an overdraft buffer up to \$10. Approximately, five of ten accounts in our sample have used an overdraft buffer at least once.

\footnotetext{
${ }^{5}$ Some accounts in our sample were assessed monthly fees other than $\$ 4.95$ and $\$ 9.95$. These exceptions to the fee programs are for certain groups of consumers, such as employees of NetSpend or its partners.

6 The amount was increased to $\$ 5$ after the end date of our data (June 30, 2012).

${ }^{7}$ Cardholders must opt-in overdraft protection service. To qualify for the service, cardholders need to receive a direct deposit to their cards.
} 


\subsection{Other Data Sources}

Several other data sources are also used for this study. First, county level data from the 2011 American Community Survey, 2011 Current Population Survey, 2010 US Census, 2009 Census Small Area Income and Poverty Estimates, and the 2010 FBI Uniform Crime Report are used to examine what county characteristics affect the penetration rate of NetSpend cards in each county. These county data include demographic characteristics as well as information on federal direct payments to individuals (e.g., for retirement), poverty and unemployment rates, household structure, and violent and property crime metrics. We supplement these data with rates of unbanked and underbanked households at the state level as reported in the 2011 FDIC National Survey of Unbanked and Underbanked Households.

For the purposes of the other regression analysis, we again use the 2011 American Community Survey. Whereas we use county-level aggregates for the penetration analysis, here we use aggregates at the census tract level. As mentioned above, the NetSpend datasets contain only limited information on account holders; the zip code of account creation is the only geographic indicator for the account. Therefore, we take the census tract data and re-aggregate to a zip code level. To do this, we rely on the US Department of Housing and Urban Development's HUD-USPS crosswalk files from the fourth quarter of 2011. We generate zip code count estimates by adding together the count estimates of all census tracts which overlap with a given zip code. Census tracts which overlap more than one zip code are included in the calculations for multiple zip codes. Once the aggregation process is complete, we recalculate demographic shares (e.g., share of females) by zip code and merge with NetSpend's account 
level data. As a precautionary measure, we limit our analysis to accounts created in standard zip codes, i.e., we exclude unique and PO Box only zip codes. ${ }^{8}$

\section{Penetration of General Purpose Reloadable Prepaid Cards}

To understand the penetration of prepaid cards in the local market, Figure 3.1 plots the number of active NetSpend accounts over the one year period from July 1, 2011 to June 30, 2012 per 10,000 residents in each county. Penetration rates are generally higher in the South and Southeast. This pattern is similar to the FDIC's survey data on unbanked and underbanked consumers and the payroll card penetration found in Wilshusen et al. (2012). Within these regions, penetration rates in Texas are higher than in any other states. ${ }^{9}$

We further examine what county characteristics, if any, affect the penetration rate by using county level data from the 2010 census among other sources. Table 3.1 presents the results of a simple OLS regression. As expected, the shares of unbanked and underbanked households and prepaid card penetration rates are positively correlated. If the shares of unbanked and underbanked households increase by 1 percentage point in a state, the number of NetSpend accounts per 10,000 residents in each county in the state will increase by 1.8 and 1.4 , respectively. That said, several other variables are statistically significantly correlated with the prepaid card penetration rates even after controlling for unbanked and underbanked shares.

Not surprisingly, Federal expenditures on direct payments to individuals other than for retirement and disability (e.g., food stamps and refunded earned income tax credit) are positively correlated with prepaid card penetration rates. However, neither the share of households under

\footnotetext{
${ }^{8}$ In the current draft, zip code level demographic information is used to analyze accounts in Texas. Approximately 0.5 percent of the accounts within Texas are excluded due to unique and PO Box only zip codes.

${ }^{9}$ This may be at least partially affected by the company's location. NetSpend's headquarters are located in Texas.
} 
the poverty line nor the shares of different income groups are statistically correlated with penetration rates.

The shares of different age groups or different educational attainment groups have statistically significant effects, though the effects are somewhat unexpected. Penetration rates are higher in counties where the share of young residents is relatively small and where the shares of residents with a high school diploma or bachelor's degree are higher.

Household structure also affects the penetration rates. As the share of married couples increases, the penetration rates decrease. The share of single household, both male and female, is negatively correlated with the penetration rate (although statistically insignificant for male households). The share of single mother family is positively correlated with the penetration rate, while the share of single father family has a statistically insignificant correlation.

The prepaid card penetration rates are also affected by race and by ethnicity. The higher the share of Hispanic residents, the higher the penetration rate is. In contrast, as the share of American Indian or Alaska native residents increases, the penetration rate declines.

Finally, two types of crime rates have significant effects on the penetration rate. As the number of violent crimes per 10,000 residents increases by 1 (the average is 25 crimes), the number of NetSpend accounts per 10,000 residents increases by 0.12 , while as the number of property crimes per 10,000 residents increases by 1 (the average is 204) the number of NetSpend accounts per 10,000 residents increases by 0.07 .

\section{Use of General Purpose Reloadable Prepaid Cards}

\subsection{The Life Span of Cards}

How long do prepaid cardholders use their cards? To obtain statistics about the life span of prepaid cards, we cannot simply calculate the mean or median of the time span between the 
account creation date and the last debit date in our dataset. There are two problems with using this method. First, many of the accounts in our sample are likely to be active beyond the last cutoff date of our dataset, June 30, 2012. Thus, calculating the life span of the cards based on the last debit date is likely to underestimate the mean or median life span. Second, our dataset includes only those accounts that were active at some point in the one year period between July 1, 2011 and June 30, 2012. This causes the mean or median life span of the accounts in our sample to be biased upward. For example, let us suppose three accounts were created on January 1, 2011. The first account survived until May 1, 2011, the second account survived until September 1, 2011, and the third account survived until January 1, 2012. The mean life span of these three accounts is $8(=(4+8+12) / 3)$ months. However, the first account is not included in our dataset because it did not survive until July 1, 2011. The mean life span of the two accounts we observe in the dataset is 10 months, which is 2 months longer than the true mean life span.

To avoid these biases, we adopt two methods to analyze the life span of prepaid cards. The first method is to compute survival rates for various characteristics of accounts, such as load types, fee program types and so on, by calculating the conditional survival probability. The second method is to estimate account survival using a proportional hazards model with a covariate vector of various account characteristics and zip code level demographic characteristics. In both methods, we assume an account remains active beyond June 30, 2012 if the last debit date of the account falls within June 2012.

For survival rates, we first calculate the conditional survival probability of accounts in the $\mathrm{t}+1^{\text {th }}$ period since creation, given the $\mathrm{t}^{\text {th }}$ period survival. More specifically, we count two numbers to compute the conditional survival probability. One is the number of accounts that satisfy two conditions. The first condition is that the account survived until its $t^{\text {th }}$ period or longer 
since its creation and the second condition is that the account's $\mathrm{t}^{\text {th }}$ period falls between July 1 , 2011 and June 30, 2012. Let $x$ denote the number of such accounts. The other number is the number of accounts that survived at least until its $t+1^{\text {th }}$ period among the accounts we first counted. Let y denote the number of accounts in this subgroup. The conditional survival probability from the $\mathrm{t}^{\text {th }}$ period to the $\mathrm{t}+1^{\text {th }}$ period is $\mathrm{y} / \mathrm{x}$. We calculate the conditional survival probability for each $\mathrm{t}^{\text {th }}$ period.

We then calculate survival rates by multiplying conditional survival probabilities. The $\mathrm{t}+1^{\text {th }}$ period survival rate is the product of the $\mathrm{t}^{\mathrm{th}}$ period survival rate times the conditional survival probability in the $t+1^{\text {th }}$ period given the $t^{\text {th }}$ period survival. We define 30 days as one period and compute survival rates by various account characteristics, such as load type, fee program type, card distributor type, and so on.

Chart 4.1 plots survival rates for all accounts in out sample. Fifty percent of all accounts in our sample became inactive or terminated around the third period since the account creation date, implying that the median life span of all accounts in our sample is about 90 days. The mean life span, however, is much longer-347days. More than a quarter of all accounts survive beyond one year. The life span of the cards in our sample is comparable to that of cards analyzed in Wilshusen et al. (2012). Cards in our sample (which are all GPR cards) survived longer than GPR cards distributed by retailers in the sample used in Wilshusen et al. (the median life span is 63 days) but shorter than GPR cards distributed over the web or by financial institutions (the median life span is 184 days and 189 days, respectively) in their sample.

Survival rates vary significantly by load type and by fee program type. Charts 4.2 and 4.3, respectively, plot survival rates by load type and by fee program type. Obviously, accounts without reloads are short-lived—-the median life span is shorter than 30 days. Among accounts 
with reloads, accounts with periodic direct deposits survive longer than accounts with occasional reloads (the median life span is 330 days) or accounts with periodic self-funded reloads (the median life span is 60 days). Among accounts with periodic direct deposits, accounts with government direct deposits survive longer (the median life span is 1440 days, more than 3 years) than accounts with non-government direct deposits (the median life span is 570 days). With respect to the fee programs, accounts with monthly fees survive much longer than accounts with per-transaction fees (the median life span is 300 days vs. 60 days).

Survival rates are also correlated with other account characteristics, such as type of card distributors, whether account holders utilize alert services, whether account holders utilize emails, customer service calls, or web to communicate with the card program manager, or whether account holders ever made overdraft transactions. Table 4.1 presents the median and mean life span for different types of accounts. Accounts of cards that were distributed directly by the program manager generally survived longer than accounts of cards that were distributed in other ways. Accounts that utilized alert services, email, and web survived longer than accounts that did not. And accounts that had ever made overdraft transactions survived much longer than those that had not.

We now estimate prepaid card account survival using the semi-parametric Cox Proportional Hazards model to quantify the effects of various account characteristics on survival. In specification 1, covariates consist of account characteristics. To test whether zip code level demographic characteristics affect survival rates, specification 2 adds those demographic characteristics to the covariates in specification 1 . (In this draft, specification 2 is used to analyze only the accounts in Texas. Later we will expand our analysis to other states or to the whole country). 
Table 4.2a shows coefficients for account characteristics. The first column reports the result of specification 1 using the entire national sample, the second column is the results of specification 1 using the Texas sample, and the third column is the results of specification 2 using the Texas sample. All coefficients are statistically significantly different from zero. The signs of the coefficients for the account characteristics are consistent with the variation of survival rates we found above. For instance, relative to the accounts with periodic self-funded reloads, the hazards rate (i.e., the risk of becoming inactive or terminated) is higher for accounts without reloads and lower for accounts with occasional reloads, periodic government direct deposits, and periodic non-government direct deposits.

Among account characteristics, load type has the strongest effect on survival. Even after controlling for other characteristics, the probability of accounts becoming inactive or being terminated in a 30-day period is about two times greater for accounts without reloads than for accounts with periodic self-funded reloads. The risk is much smaller for the other reload types: relative to the termination risk for accounts with periodic self-funded reloads, the risk for accounts with occasional reloads or for accounts with periodic non-government direct deposits is less than half, and the risk for accounts with periodic government direct deposits is less than onesixth. Another account characteristic that strongly influences survival is the overdraft buffer. If accounts used an overdraft buffer at least once, then the risk of termination is about one-third of the risk for accounts that did not use such buffers.

Table 4.2b presents coefficients for zip code level demographic characteristics in specification 2 using the Texas sample. Various demographic characteristics have statistically significant effects on hazard rates. As the share of female residents in a zip code increases by 1 percent point, the risk for the accounts in the zip code becoming inactive in a 30-day period 
increases by 0.57 percentage points. The share of American Indian in a zip code negatively affects hazard rates (i.e., positively affects survival) of accounts in the zip code, while the share of multiple race affects hazard rates negatively. Accounts are less likely to be terminated earlier in zip codes where the shares of age groups of 45 to 64 are greater. Accounts are also less likely to be terminated earlier in zip codes where the shares of educational attainment of less than $9^{\text {th }}$ grade and of graduate degree are greater and the shares of married couple and widowed are greater. While the violent crime rate in a zip code positively affects hazard rates, the property crime rate has no significant effect.

Including zip code level demographic characteristics improves the model fit. Although the log-likelihood does not improve much from specification 1 to specification 2, the null hypothesis that there are no omitted variables for specification 1 is rejected at the 1 percent significance level. Several zip code level demographic characteristics have coefficients that are statistically significantly different from zero. However, cautious interpretation is required because we do not know if those characteristics can be directly mapped to individual account holders' characteristics. For example, our results suggest that accounts in zip codes where the share of female residents is relatively large tend to be short-lived, but this may not necessarily imply female account holders tend to keep their accounts shorter than male account holders.

\subsection{Load and Debit Activities}

How intensely do prepaid cardholders use their cards? To answer this, we examine load and debit activities per month, instead of over the life of the account since they can be significantly influenced by the life span of the account. As shown above, the life span of the account varies by account characteristics as well as demographic characteristics in the zip code of the account. Does the intensity of card use, such as the number or value of load and debit 
transactions per month, also vary by account characteristics or demographic characteristics of zip code? We first describe the average load and debit activities per month for different account characteristics and then examine what factors influence those activities by conducting a regression model analysis.

Load and debit activities undertaken by GPR prepaid cardholders in our sample are presented in Table 4.3. On average, cardholders loaded funds to their account 1.8 times per month in an average value of \$286 and made debit transactions 8.2 times per month in an average value of $\$ 55$. This implies the total value of loads per month is $\$ 516$ (=\$286*1.8), and the total value of debit transactions per month is $\$ 452(=\$ 55 * 8.2)$.

Cardholders in our sample used their cards more intensively than did cardholders in the sample used in another study. Rhine et al. (2007) drew 2,000 prepaid card holders from four firms in the industry over the 2005-2006 timeframe and found that the cardholders in their sample made 1.0 load and 4.3 debit transactions per month on average. The difference may imply that prepaid card holders now use their cards more intensively than 5 to 6 years ago or that the intensity of card use may vary by company providing prepaid card services.

The load activities significantly vary for different account characteristics. By definition, the number of loads per month is greater for accounts with periodic reloads than for those with no or occasional reloads. Accounts that were assessed monthly fees had more loads per month than accounts that were assessed per transaction fees. Accounts of cards that were distributed by check cashers or retail stores had more loads per month than accounts of cards that were distributed in other ways. Accounts that utilized an alert service had more loads than accounts that did not, but the number of loads did not vary whether or not the accounts utilized services such as email, customer service call, or web. Accounts that had ever overdrawn funds had more 
loads per month. The average amount per load was greater for accounts with direct deposits, accounts that were assessed monthly fees, accounts of cards that were directly distributed or distributed by tax preparers, and accounts that had overdrawn funds.

More pronounced are the differences in the number of debit transactions per month for different account characteristics. The average number of debit transactions is only 2.3 times per month for accounts with occasional reloads, while holders of accounts with non-government direct deposit made debit transactions 21 times per month. Accounts with monthly fees made 17.6 debit transactions per month, while accounts with per transaction fees made only 5.4 transactions. Accounts of cards that were distributed by tax preparers made almost 15 transactions per month, while accounts of cards that were distributed by others made less than 10 transactions. Accounts that had overdrawn funds were the most debit active-they made more than 23 debit transactions per month. The average amount per debit did not vary very much for different account characteristics, except for accounts without reload and accounts of cards that were distributed by tax preparers. These accounts had much large average amounts per debit transaction.

We now turn to a regression analysis to see if debit activities vary by account characteristic or zip code level demographic characteristic. Table 4.4 presents the results of OLS regressions of the number and the value of debit transactions per month. Similar to the hazards model above, we use two specifications. Specification 1 includes account characteristics and shares of three of the four debit types. Specification 2 adds zip code level demographic characteristics to the variables in specification 1 . For specification 1 , the entire national sample and the Texas sample are used, while for specification 2 the Texas sample is used. Coefficients for account characteristics and the shares of three debit types are reported in Table 4.4a and 
coefficients for zip code level demographic characteristics in specification 2 are reported in Table 4.4b.

All coefficients for account characteristics are statistically significantly different from zero and their signs are consistent with the variation of debit activities shown in Table 4.3. For instance, relative to the accounts with periodic self-funded reloads (the control group), more debit transactions were made by holders of accounts with periodic government direct deposits and periodic non-government direct deposits, and fewer debit transactions were made by holders of accounts with no or occasional reloads.

The shares of cash withdrawals, bill payments, and person-to-person transfers all have statistically significant effects on debit activities. Interestingly, the higher the shares of cash withdrawals and bill payments among debit transactions, the more debit transactions were made per month. For example, if the share of bill payments increases by 1 percentage point, the number of debit transactions per month increases by 0.15 and the value of debit transactions per month increases by $\$ 18$.

All types of demographic characteristics in zip codes affect the number and value of debit transactions per month. Accounts in zip codes where the share of female residents is larger are more likely to make more debit transactions per month. The share of black residents and the share of Hispanic residents in a zip code are negatively correlated with the volume and value of debit transactions per month. The shares of the very young age group (15 and under) and of middle to old age groups (45 and over) are also negatively correlated with monthly debit activities. As the share of residents with associate's or graduate degree increases in a zip code, accounts in the zip code tend to make fewer debit transactions. The volume and value of debit transactions are more likely to be greater for accounts in zip codes where the shares of higher 
income residents are larger. The share of divorced residents in a zip code is positively correlated with monthly debit activities. Finally, both violent and property crime rates affect the volume of debit transactions per month but not the value. The violent crime rate is negatively correlated and the property crime rate is positively correlated with the volume of transactions.

Similar to the hazards model above, including zip code level demographic characteristics improves the model fit. The adjusted R-squared increases from specification 1 to specification 2 for both the volume and value of debit transactions per month. The null hypothesis that there are no omitted variables for specification 1 is also rejected at the 1 percent significance level.

\subsection{Shares of Various Debit Transactions}

How prepaid card holders use their cards is of great interest. Do they use their prepaid cards to purchase goods and services or mainly just to access cash? Are there any distinct differences between purchasers and cash withdrawers? In this section, we first describe transaction patterns and then examine what factors influence each account's shares of purchase transactions and cash withdrawals, the two main types of debit transactions.

As mentioned above, account holders in our sample can make four types of debit transactions: (i) purchase transactions; (ii) cash withdrawals; (iii) bill payments; and (iv) personto-person transfers. Purchase transactions include transactions at the point of sale (POS) as well as over the Internet. They also include bill payments if those payments are processed over card networks. Cash withdrawals are mainly ATM cash withdrawals, but they can be made over the counter as well. Account holders can make bill payments by entering their account information at the online account center, just as a bank account holder can make a bill payment at the bank's 
online banking site. These bill payments are not processed over card networks. Finally, account holders can make person-to-person money transfers. ${ }^{10}$

Statistics on four types of debit transactions are presented in Table 4.5. The first column shows the share of accounts that used each of the four types of debit transactions. Almost 100 percent of accounts (97 percent) made at least one purchase transaction, while only 50 percent of accounts made at least one cash withdrawal. The shares of accounts that made at least one bill payment and at least one person-to-person transfer are even smaller (0.8 percent and 9.7 percent, respectively). The second and third columns report the average share of each type of debit transactions in volume and in value for all accounts, while the fourth and fifth columns report the average share among users. Regardless of whether it is calculated for all accounts or limited to users, the average share of purchase transactions is approximately 90 percent in volume and 80 percent in value. The average share of cash withdrawals is 12 percent in volume and 19 percent in value for all accounts but among users is 23 percent in volume and 37 percent in value. The average shares of bill payments and person-to-person transfers are much smaller. Even among users, the share of bill payments is about 3 percent in volume and 7 percent in value and the share of person-to-person transfer is 7 percent in volume and 14 percent in value. The sixth column shows the average value per transaction for each type. The average value per purchase transaction is $\$ 52$, which is about a half of the average value per cash withdrawal (\$108). The average value per bill payment and that per person-to-person transfer are much greater. The former exceeds $\$ 300$, and the latter is about $\$ 245$.

Account holders in our sample made relatively fewer ATM transactions as compared with other prepaid card users. Wishusen et al. (2012) found that the share of cash withdrawals in

\footnotetext{
${ }^{10}$ Person-to-person transfers are limited among NetSpend cardholders.
} 
volume among prepaid cards with at least one cash withdrawal is between 34 percent and 50 percent depending on card type (payroll or GPR distributed via retail, financial institution, or web), which is much higher than the average of our sample of 23 percent. Neither our dataset nor theirs may be representative of the industry as a whole.

Tables 4.6 and 4.7 provide more detailed statistics on the four types of debit transactions. The use of ATM transactions and person-to-person transfers significantly varies by account characteristic. Accounts that receive direct deposits are more likely to make ATM transactions or person-to-person transfers than accounts that were never reloaded. Accounts that pay monthly fees tend to make both those transactions more than accounts that pay per-transaction fees. All four types of debit transactions are more likely to be made by accounts that have ever made overdraft transactions than accounts that have not. The share of bill payments or person-toperson transfers in each account holder's debit transactions does not vary across different types of accounts, while the shares of purchase transactions and of ATM transactions vary. For example, the average ATM share in volume exceeds 25 percent for account holders who receive direct deposits from the government or for those who obtained their cards from tax preparers, while the share falls to less than 10 percent for those who periodically reload funds by themselves and for those who obtained their cards at retail stores.

To further examine what factors affect the shares of purchase transactions and cash withdrawals, we run OLS regressions. Again, we use two specifications: Specification 1 includes account characteristics and specification 2 adds zip code level demographic characteristics. For specification 1, we use both the national sample and the Texas sample and for specification 2 , we use only the Texas sample. Coefficients for account characteristics are reported in Table 4.8a and those for zip code level demographic characteristics are in Table 4.8b. 
Almost all account characteristics have statistically significant effects and a gain or loss of purchase transaction share is almost always offset by a loss or gain of cash withdrawal share. Relative to the accounts with periodic self-funded reloads (the control group), the other load type accounts have a greater cash withdrawal share. In particular, accounts with periodic government direct deposits have a much greater cash withdrawal share than accounts with periodic selffunded reloads. The share difference is 17 to 19 percentage points in volume and 28 to 29 percentage points in value. Given the overall average share of cash withdrawal is 12 percent in volume and 19 percent in value, this difference is enormous. Accounts associated with per transaction fees have a larger cash withdrawal share than accounts associated with monthly fees, but the difference is modest (only 2 percentage points in volume and 1 percentage point in value). Accounts of cards that were distributed by tax preparers or through disbursement have much larger cash withdrawal shares than accounts of cards that were distributed in other ways. Accounts that made overdraft transactions have a relatively larger cash withdrawal share, while accounts that were offered overdraft buffer have a relatively larger purchase transaction share. Accounts that utilized email have a relatively larger share of purchase transactions, while accounts that utilize customer service call or web have a relatively larger share of cash withdrawals.

Several zip code level demographic characteristics have statistically significant effects. Accounts in zip codes where the share of black residents is relatively large tend to have a relatively large share of cash withdrawals, while accounts in zip codes where the share of Asian residents is relatively large tend to have a relatively large share of purchase transactions. The shares of the very young age group (15 and under) and of old age groups (55 and over) in a zip code are positively correlated with the purchase transaction share. The share of residents without 
a high school diploma is negatively correlated with the share of purchase transactions and so is the share of residents with graduate degree. Finally, accounts in zip codes where violent crime rate is higher tend to have a larger cash withdrawal share.

Similar to the hazards model analysis and regression model analysis on debit activities, the model fit improves when zip code level demographic characteristics are included in the model. The adjusted R-squared increases from specification 1 to specification 2 for both the shares in volume and value of purchase transactions and of cash withdrawals. The null hypothesis that there are no omitted variables for specification 1 is also rejected.

\subsection{Composition of Purchases}

Where do prepaid cardholders make purchase transactions? The analyses in this section use the account level dataset as well as the second dataset, which contains all purchase transactions and cash withdrawals on NetSpend cards during June 2012.

\subsubsection{Account level analysis}

When prepaid cardholders make a purchase transaction, do they have preference for their authorization methods—-personal identification number (PIN) or signature? Does the fee difference between PIN and signature authorizations affect their choice? We first describe the average purchase activities per month for different account characteristics and then examine whether the fee difference between PIN and signature affects a prepaid cardholder's choice.

Table 4.9 presents the average monthly purchase transactions in volume and in value, as well as the average shares of three types of purchase transactions: PIN-based, signature-based $\mathrm{CP}$, and signature-based CNP transactions. To calculate the average shares for all account holders or each account holder group, each account holder is weighted equally (i.e., the average is not weighted by transaction volume or value). 
The average number of purchase transactions made per month is 7 for an average aggregate value of \$303 each month. Cardholders, on average, make approximately 30 percent of their purchase transactions with PIN-based and the rest with signature-based. However, since signature-based card-not-present transactions account for more than 40 percent, the share of signature-based card-present transactions is slightly smaller than the share of PIN-based transactions. This implies that cardholders are more likely to select PIN over signature when they can choose between the two in the CP environment. However, in the CNP environment such as the Internet or phone, PIN-based transactions are typically unavailable.

Similar to the debit activities shown in Section 4.2, both purchase transaction volume and value per month significantly vary by account characteristic. Account holders who receive direct deposits on their cards, those who pay a monthly fee, and those who have overdrawn their prepaid card accounts tend to make more purchase transactions.

Distribution of purchase transactions across the three types also varies by account characteristic. The share of signature-based CNP transactions exceeds 50 percent among cardholders who periodically reload funds on their cards by themselves and among those who obtained their cards at retail stores. On average, the PIN share is greater than the signature CP share; however, the PIN share in volume is smaller among seven groups of cardholders and the PIN share in value is smaller among one group—cardholders who occasionally reload funds on their cards.

We now examine how the choice between PIN and signature differs between cardholders who pay per transaction fees and those who pay monthly fees. Cardholders who pay per transaction fees in our sample are assessed a $\$ 1$ fee for a signature-based transaction and a $\$ 2$ fee for a PIN-based transaction, while neither fee is assessed to cardholders who choose the monthly 
purchase fee plan. Among cardholders who pay a monthly fee, the PIN share is more than 10 percentage points greater than the signature CP share, while among cardholders who pay per transaction fees, the two shares are about the same.

To test whether the fee differences discourage PIN-based transactions among cardholders who pay per transaction fees or other factors affect their choice, we run an OLS regression on the PIN share as well as on the signature CNP share (the results are shown in Tables 4.10a and 4.10b). Our results suggest that the lower average PIN share among cardholders who pay per transaction fees are explained not only by the fee difference but also by a difference in demand for CNP transactions. Even after controlling for other factors, a dummy indicating a cardholder pays per transaction fees is negatively correlated with the PIN share and positively correlated with the signature CNP share: Cardholders who pay per transactions fees have a 5.3 percentagepoint (a 6.7 percentage-point, in the Texas sample) lower PIN share in volume and a 3.6 percentage-point (a 5.5 percentage-point, in the Texas sample) higher signature CNP share in volume than otherwise similar cardholders who pay monthly fees. The positive correlation between the per-transaction fee dummy and the signature CNP share indicates that cardholders who pay per transaction fees make relatively more signature-based CNP transactions than cardholders who pay the monthly fee. However, their demand for CNP transactions does not completely explain their lower share of PIN transactions because the size of coefficient on the per-transaction-fee dummy in the signature CNP share model is smaller than that in the PIN share model. Thus, the fee difference--the higher fee for a PIN transaction than for a signature transaction—discourages cardholders to make PIN transactions, but it only reduces the PIN share in volume by 1.7 percentage points (1.2 percentage points, in the Texas sample). 


\subsubsection{Analysis of transactions in June 2012}

Although we can observe the distribution of purchase transactions by authorization method (PIN vs. signature) and card-present vs. card-not-present from the account level dataset, we cannot observe more detailed composition of purchase transactions, such as at what types of merchants cardholders make transactions more often, whether cardholders obtain cash at pointsof-sale, and so on. To examine more detailed purchase transactions, we use the second dataset that contains all purchase and cash withdrawal transactions during a month of June 2012 and compare statistics of this dataset and findings in other studies.

Table 4.11 reports the distribution between cash withdrawals and purchase transactions. The share of cash withdrawals is smaller than that of purchase transactions in terms of both volume and value — the share of cash withdrawals is 13 percent in volume and 34 percent in value. ${ }^{11}$ The cash withdrawal share is relatively higher in value because the average ticket size of cash withdrawals is more than three times greater than that of purchase transactions ( $\$ 128.83$ vs. \$37.51). These statistics are comparable to those from the 2010 Federal Reserve Payments Study (FRPS). Gerdes (2011) analyzed prepaid card volumes and trends from the 2010 FRPS and found that the distribution between ATM withdrawals and purchase transactions on network branded prepaid cards were 9 percent vs. 91 percent in terms of volume and 33 percent vs. 67 percent in terms of value. Cardholders in our sample use their cards at ATMs relatively more often than other network-branded prepaid card holders. Nevertheless, the distribution in terms of value is almost identical between cardholders in our sample and network-branded prepaid cards as a whole.

\footnotetext{
${ }^{11}$ As will be discussed in the next section, ATM transaction value includes surcharges assessed to cardholders by ATM owners. Our estimation of the average ATM surcharge (including zero surcharges) is $\$ 2.26$ to $\$ 2.33$ per transaction. After excluding surcharges, the share of ATM transactions in value becomes 33.4 percent.
} 
Table 4.12 presents the distribution among purchase transactions. They are divided into two authorization types, PIN or signature. PIN transactions are further divided into three groups-PIN-less bill payments, purchase-only, and purchase with cash back transactions. Typically, PIN debit networks do not process transactions over the Internet, but bill payments are an exception. Some PIN debit networks process bill payments initiated over the Internet at certain companies, such as telecommunications and cable companies, without requiring the cardholders to authenticate themselves with PIN. Unlike signature debit networks, PIN debit networks allow consumers to obtain cash when they make purchase transactions at the point of sale. Thus, some purchase transactions authorized with PIN involve cash back as well. Signature transactions are divided into two groups: CP and CNP.

The share of PIN transactions is smaller than that of signature transactions in terms of volume (35.4 vs. 64.6 percent) as well as value (42.4 vs. 57.6 percent). The majority of PIN transactions are purchase-only transactions, but the share of PIN-less bill payments in PIN transactions in terms of value is close to 20 percent (=7.6/42.4). In signature transactions, the share of CP transactions is larger than that of CNP transactions in terms of volume (65.8 vs. 34.2 percent), but it is smaller in terms of value (39.8 vs. 60.2 percent).

Statistics on PIN vs. signature distribution of prepaid cards are reported in Wilshusen et al. (2012). Payroll cards and web-distributed GPR cards in their sample have a higher PIN share than our sample, but retail- and financial institution-distributed GPR cards have a lower PIN share. The Federal Reserve Board (2012) reported the overall debit and prepaid card distribution between PIN and signature: In 2011, signature transactions represented about 63 percent of transaction volume and 61 percent of transaction value. In contrast to these overall debit and 
prepaid card statistics, the share of signature transactions in our dataset is slightly larger in volume, but 3 to 4 percentage points smaller in value.

Gerdes (2011) reported statistics on cash back in terms of value: $\$ 41.5$ billion total purchase value and $\$ 1.3$ billion total cash back value, implying the total cash back value is about 3 percent of the total value of POS transactions on network-branded prepaid cards. Applying his statistics, we obtain a reasonable average cash back amount per transaction. Our statistics suggest the share of purchase transaction that involves cash back is 6.9 percent in terms of value. Applying 3 percent as cash back value, then the rest, 3.9 percent (=6.9-3), is purchase value. Given the average ticket size of $\$ 66.58$, the average cash back amount is calculated to be $\$ 29$ $(=66.58 * 3 / 6.9)$. The average purchase amount of purchase transactions with cash back is calculated to be about $\$ 37$, which is very close to $\$ 35.95$, the average purchase amount of purchase-only transactions.

The Federal Reserve System (2011) reported detailed statistics in the 2010 FRPS, including, among other things, CP vs. CNP signature debit transactions. The share of CNP signature debit transactions is 15 percent in volume and 25 percent in value. In contrast, the share of CNP signature transactions in our dataset is 34 percent in volume and 60 percent in value. This striking difference may be caused by some of the prepaid card users’ (such as unbanked and underbanked consumers') limited access to payment methods, namely cash and prepaid cards. Prepaid cards are likely to be the only method that allows them to make transactions over the Internet, phone, or mail.

Tables 4.13a and 4.13b report top ten merchant categories in volume and in value, respectively. Service stations and grocery stores rank within top three in volume as well as in value. Fast food restaurants, restaurants, discount stores and telecommunications rank within top 
ten in volume and value. Merchants with a physical presence, such as drug stores, miscellaneous food stores, and closing stores rank within top ten in terms of volume, while billers, such as cable, utilities, and insurance, rank within top ten in terms of value. Video/DVD rental stores, a merchant category in an entertainment sector, rank in the top ten in volume.

Our findings are very similar to those in Wilshusen et al. (2012). Purchases at three types of stores—grocery stores, service stations, and fast food restaurants—alone account for about half of all purchase transactions and about a third of transaction value in their dataset as well as ours. They also found that restaurants, telecommunications and utilities are well represented in purchase transactions.

We further explore top merchant categories for different types of transactions, reported in Table 4.14. Several interesting observations are made. First, gas stations and grocery stores rank higher for both PIN (purchase-only as well as purchase with cash back) and signature CP transactions. Second, some merchant categories rank higher for one type of authentication method but not for others: fast food and general restaurants rank higher for signature CP transactions but not for PIN transactions, while discount stores rank higher for PIN transactions but not for signature transactions. Third, cash back transactions are highly concentrated. More than 50 percent in volume and more than 60 percent in value of cash back transactions were made at grocery stores. The U.S. Postal Service is among the most popular cash back locations. Similarly, PIN-less bill payments are highly concentrated: the top five merchant categories jointly generate more than 90 percent of transaction volume and value. Finally, in contrast to the concentration for PIN cash back transactions and PIN-less bill payments, signature CNP transactions are more evenly distributed among merchant categories. The joint market share of top five merchant categories is well below 40 percent in volume or in value. We cannot compare 
our results here because, as far as we know, no previous studies explored composition of purchase transactions at this level of detail.

\section{Fees}

What it costs to use a GPR prepaid card is also of great interest. In the account level dataset, we can observe all types of fees cardholders pay to their card issuers over the life of the account. Reload fees paid to retailers or check cashers that participate in the reload network and ATM surcharges paid to ATM owners are not included in this dataset. Although we have no data about reload fees paid by cardholders to third parties, we can estimate ATM surcharges by using the second dataset used in the previous section. ${ }^{12}$ Subsection 5.1 analyzes fees received by card issuers. We present statistics on the aggregate fees paid by cardholders to their card issuers for each month, as well as statistics on the aggregate fees relative to debit activities because fees and debit activities are highly correlated. We, then, conduct a regression analysis to examine what factors influence the relative fees. Subsection 5.2 estimates ATM surcharges charged to cardholders.

\subsection{Fees received by card issuers}

Table 5.1 presents distribution of cardholder fees received by card issuers for each month. Both the number and value of fees cardholders pay to their issuers vary significantly. Cardholders at the 10th percentile incur 1.0 fee per month and the average monthly fee amount is $\$ 1.35$, while cardholders at the 90th percentile incur 15.7 fees and the amount is $\$ 26.44$. The mean and median numbers of fees per month are 6.8 and 4.0, respectively, and the mean and median values of fees per month are $\$ 11.00$ and $\$ 6.37$, respectively. Cardholders in our sample incur relatively higher fees, compared with the sample used in Wilshusen et al. (2012). In their

\footnotetext{
${ }^{12}$ A supplemental dataset provided by NetSpend allows us to observe reload locations during June 2012.
} 
sample, the mean and median values of fees per month for web GPR programs are \$8.16 and \$5.88, respectively, which are the highest among four programs-payroll, financial institution GPR, retail GPR and web GPR programs.

Card issuers assess several different fees to cardholders. Chart 5.1 shows the average fee composition in volume and value among all account holders in our sample. We first calculate shares of each type of fees for each account holder, and then compute the average share of each fee by treating all account holders equally. Signature transaction fees have the largest share in both volume and value. PIN transaction fees have the second largest share, but if two balance inquiry fees (ATM and IVR) are combined, the combined fee share exceeds the PIN transaction fee share in volume. ATM withdrawal fees have the third largest share. Both monthly fees and account maintenance fees are less than 10 percent in volume and in value.

The number and value of fees significantly vary by account characteristic partly due to significant variation in debit activities. It may be natural that cardholders who make more transactions incur more fees. To examine who incurs more fees relative to debit activities, we calculate the number and value of fees relative to the number of debit transactions. The fee variation diminishes significantly, but both the relative number and value of fees vary by account characteristic (Table 5.2). For example, account holders who receive direct deposits from the government incur 1.4 fees per debit transaction, while account holders who receive direct deposits from non-government entities incur 0.8 fees per debit transaction. Account holders who obtained their cards through disbursement incur $\$ 2.75$ per debit transaction, while those who obtained their cards directly from card program manager incur \$1.60 per transaction.

To examine what factors affect the relative fees, we run OLS regressions. Table 5.3 shows the results. All account characteristics have a statistically significant effect. Compared 
with cardholders who periodically reload funds on their cards by themselves (the control group), cardholders who receive direct deposits from non-government entities incur fewer fees relative to their number of debit transactions whereas cardholders in the remaining reload groups incur relatively more fees. Cardholders who are in the per-transaction fee program incur a 34-cent higher fee (a 37-cent higher fee in the Texas sample) per debit transaction than cardholders who are in monthly fee programs. Cardholders who obtained their cards at check cashers (the control group) incur relatively more fees than cardholders who obtained their cards in other ways. Cardholders who utilize email, web, or alert services incur fewer fees than those who do not. Cardholders who have overdrawn their prepaid card accounts incur relatively fewer fees, but they incur a 27-cent higher fee per debit transaction than cardholders who have never overdrawn.

How cardholders use their cards also affects relative fees. Cardholders who heavily use their cards for ATM withdrawals tend to incur higher fees relative to their debit transactions. Cardholders whose PIN share and signature CNP share in their purchase transactions are higher tend also to incur higher fees.

Unlike account characteristics, the effects of zip code level demographic characteristics on the relative fees are limited. Cardholders in zip codes where the shares of black residents are larger are more likely to incur higher fees relative to their debit activity. Cardholders in zip codes where the shares of residents with graduate degree or associate degree are larger also tend to incur higher fees. The two types of crime rates have opposite effects: Cardholders in zip codes where violent crime rates are higher are more likely to incur higher fees per debit transaction, while cardholders in zip codes where property crime rates are higher tend to incur lower fees per debit transaction. 


\subsection{ATM surcharges}

We now turn to ATM surcharges, which are paid to ATM owners. We do not observe the exact amount of ATM surcharges; however, we can observe the amount of each ATM withdrawal made during June 2012, which includes the amount of ATM surcharge. For example, if we observe an ATM withdrawal with the amount of $\$ 102$, it is most likely that the ATM surcharge for this withdrawal is $\$ 2$, because a typical ATM does not dispense $\$ 1$ bills. Many ATMs dispense only $\$ 20$ bills, but some ATMs dispense $\$ 5$, $\$ 10$, and $\$ 50$ bills. If we observe an ATM withdrawal with the amount of $\$ 107$, instead, the ATM surcharge could be either $\$ 7$ or $\$ 2$ (in the case that $\$ 105$ is the amount of ATM withdrawal). We estimate ATM surcharges under two alternative assumptions. The first assumption is that ATMs dispense $\$ 5$ bills and thus, no surcharges exceed $\$ 5$. The second, alternative assumption is that ATMs do not dispense $\$ 5$ bills. The first assumption estimates the lower-bound ATM surcharges, while the second assumption estimates the upper-bound.

Table 5.4 reports the results. The two different assumptions barely affect the result. The mean value of surcharge is slightly lower under the first assumption than under the second assumption; however, the median values are the same under the both assumptions. The mean value of surcharge, including zero surcharges, is $\$ 2.26$ under the first assumption and \$2.33 under the second assumption. The share of ATM withdrawals with zero surcharges is slightly higher under the first assumption (7.2 percent) than under the second assumption (6.8 percent); ${ }^{13}$ nevertheless, more than 90 percent of ATM withdrawals during June 2012 attracted ATM

\footnotetext{
${ }^{13}$ Government Accountability Office (GAO) (2013) reported that 97 percent of the cash withdrawals made at the two independent firms that responded to the GAO survey were assessed a surcharge fee in 2011.
} 
surcharges. After excluding zero surcharges, the mean value of surcharge increases to $\$ 2.43$

under the first assumption and to $\$ 2.50$ under the second assumption. ${ }^{14}$

Cardholders in our sample make 1.2 ATM withdrawals per month on average. Thus, the range of the average value of ATM surcharges paid by cardholders per month is between $\$ 2.71$ and $\$ 2.80$. Adding ATM surcharges to the fees paid to card issuers, cardholders on average pay $\$ 13.71$ to $\$ 13.80$ per month for their use of prepaid cards. In addition, cardholders need to pay reload fees (ranging from $\$ 1$ to $\$ 3.95$ per reload) if they reload funds on their cards at retailers or check cashers. ${ }^{15}$

\section{Fraud Risks}

The third dataset, along with the second dataset, enables us to analyze fraud risks surrounding prepaid cards. From the third dataset, which includes all fraudulent and disputed transactions NetSpend experienced over the years, we extract fraudulent transactions occurring during June 2012. As fraudulent transactions, we consider four reasons: (i) counterfeit, (ii) lost or stolen, (iii) account takeover, and (iv) unauthorized transactions other than (i), (ii) and (iii). To calculate fraud rates, we divide the number or value of fraudulent transactions obtained in the third dataset by the number or value of total transactions obtained in the second dataset for each type of transaction.

Table 6.1 presents overall fraud rates for different types of transactions. PIN transactions have the lowest fraud rate in terms of volume as well as value (2.45 basis points and 3.83 basis

\footnotetext{
${ }^{14}$ According to GAO (2013), the estimated average ATM surcharge fee charged by financial institutions was $\$ 2.10$ and the average surcharge fee for 100 independent ATMs surveyed was \$2.24 in 2012.

${ }^{15}$ According to the data provided by NetSpend on reload activities during June 2012, cardholders who were active during a two-month period between May 1, 2012 and June 30, 2012 made 0.82 loads on average at retailers or check cashers. This suggests that cardholders pay $\$ 0.82$ to $\$ 3.24$ reload fees per month on average, in addition to the fees paid to the issuers and ATM owners.
} 
points, respectively). Cash withdrawals have the highest rate in terms of volume (9.60 basis points), but in terms of value signature debit has the highest rate (14.20 basis points).

Even within each type of transactions, how the transactions are conducted affects fraud rates. For cash withdrawals, ATM withdrawals have a much higher fraud rate than do over-thecounter withdrawals. This may be because over the counter transactions may require stronger authentication (such as presenting an ID card) than ATM's PIN authentication. For PIN transactions, PIN-less bill payments have the highest fraud rate. Unlike the other two types of PIN transactions, this type of PIN transaction is made over the Internet and does not require cardholders to authenticate with PIN, which is likely to contribute to a higher fraud rate. For signature transactions, the CNP transactions' fraud rate is higher than that of CP transactions. Many CNP transactions do not require strong authentication of cardholders.

We also observe differences in average ticket size between fraudulent transactions and non-fraudulent transactions. For cash withdrawals, PIN purchase with cash back transactions, and PIN-less bill payments, the average ticket size does not vary regardless of whether the transactions are fraudulent or non-fraudulent. In contrast, for PIN purchase-only, signature CP, and signature CNP transactions, the average ticket size of fraudulent transactions is greater than that of non-fraudulent transactions. The difference is especially pronounced for signature CP transactions: the average ticket size of fraudulent transactions is three times greater than that of non-fraudulent transactions.

Our results are comparable to the fraud statistics reported by the Federal Reserve Board (2011 and 2013). According to Federal Reserve Board (2013), in 2011 the fraud rate of prepaid purchase transactions was 3.7 basis points (bps) in volume or 7.38 bps in value, that of PIN debit was $0.6 \mathrm{bps}$ in volume or $2.87 \mathrm{bps}$ in value, and that of signature debit was $4.3 \mathrm{bps}$ in volume or 
10.62 bps in value. If we compare our results to the Federal Reserve Board's prepaid card fraud rate, the rate is much lower than our result-5.39 bps in volume or 9.8 bps in value. The Board's PIN fraud rate is also lower than our results; however, signature fraud rate is much more similar. The Federal Reserve Board (2011) reported that fraud rates for CP and CNP signature debit in value in 2009 were 11 bps and 17 bps, respectively. The CP fraud rate is still lower than our result, but the CNP fraud rate is slightly higher than our result.

Table 6.2 reports fraud rates by reason. Counterfeit and lost or stolen are the two main reasons for fraudulent transactions for all transaction types. Counterfeit card frauds are more likely to occur for transactions over the Internet, such as PIN-less bill payments and signature card-not-present transactions, while lost or stolen card frauds are more likely to occur for inperson transactions, such as over-the-counter cash withdrawals, PIN purchase transactions and signature card-present transactions, as well as ATM cash withdrawals.

Fraud rates vary by merchant category. Table 6.3 presents fraud rates in volume and in value for largest 17 merchant categories, which have at least 1 percent share of NetSpend card transactions in both volume and value. Among these categories, direct marketing merchants have the highest fraud rate in volume and value (22.9 basis points and 25.3 basis points, respectively), while fast food restaurants have the lowest fraud rate (2.1 basis points and 2.5 basis points, respectively).

Fraud rates are generally higher among merchant categories that have larger shares of signature CNP transactions. Direct marketing, miscellaneous business services and miscellaneous professional services merchants have more than 90 percent of their transactions processed as signature CNP transactions and their fraud rates are among the highest. This is 
consistent with our findings above-signature CNP transactions have the highest fraud rates among various transaction types.

In contrast, the effect of PIN transaction share on fraud rates is not very clear. Compared with specialty retail stores, discount, drug, grocery stores have larger PIN shares and lower fraud rates. But compared with fast food restaurants, these three types of stores have larger PIN shares but higher fraud rates.

Factors other than PIN and signature CNP shares are also likely to affect fraud rates. Cable and insurance companies have quite different fraud rates, but they are very similar in terms of transaction characteristics: both are bill payments and have similar transaction compositions80 percent of their transactions are signature CNP and 20 percent are PIN transactions.

In the United States, fraud statistics on payment cards have been largely missing so far (Sullivan). Recently, the Federal Reserve Board has collected debit card fraud statistics by transaction type and by fraud type to regulate debit card interchange fees. Before that, only fraud loss rates for credit and debit card issuers had been available and little research had been undertaken on merchant losses from fraudulent transactions. Revealing fraud statistics at the level of detail shown in this section will help the industry identify risks and causes of frauds and effectively reduce fraud losses.

\section{Conclusion}

Prepaid cards are gaining traction with consumers, especially among those who do not have debit or credit cards. Penetration rates of NetSpend cards, of which all are general purpose reloadable prepaid cards, are higher in counties where the shares of unbanked and underbanked consumers are higher. Other county level demographic characteristics, such as ethnicity, 
household structure, and crime rates are also strongly correlated with penetration rates, suggesting GPR cards are more widely adopted by certain groups of consumers than others.

Prepaid cards are generally short-lived, and this is also true for reloadable prepaid cards. Approximately one of five account holders in our sample had never reloaded their cards, and the median life span of those accounts was less than a month. However, the life span of the cards varies significantly by account characteristic. Card accounts with periodic direct deposits by the government survive at least two or three years. The intensity of card use also varies by account characteristic. Cards with periodic direct deposits (either by the government or by nongovernment entities) are generally used more intensively for debit activities each month than are cards without direct deposits. Almost 100 percent of cards were used for purchase transactions while only 50 percent of them were used for cash withdrawals. The proportion of purchase transactions and cash withdrawals, however, varies considerably for different types of card accounts. Most purchase transactions on the cards were for nondurable goods and services, such as groceries, gas, and fast foods. Compared with debit card transactions, the share of CNP transactions is significantly larger, which may suggest for some consumers prepaid cards are the only payment instrument that enables them to make transactions over the Internet, by phone, or by mail.

We include zip code level demographic characteristics for our regression model specifications. Including those variables improves the model fit, suggesting that if we can use much finer-level demographic characteristics, such census tract, the model fit may improve further, and we can obtain a clearer picture of which demographic characteristics influence the use of prepaid cards. Including census tract of each account holder in the dataset may not be very 
difficult because many issuers are likely to have their customers' street address which can be easily converted to census tract.

We examine fees paid by cardholders to card issuers and ATM owners. Besides reload fees charged by retailers or check cashers, cardholders in our sample incur approximately \$14 per month on average. The number and amount of fees are positively correlated with debit activities. The number and amount of fees relative to the number of debit transactions vary significantly by account characteristic.

Lastly, we examine fraud rates on prepaid cards in considerable detail. Our results confirm that fraud rates are significantly lower for PIN transactions than for signature transactions and, among signature transactions, fraud rates are much higher for card-not-present transactions. Our results suggest fraud rates for ATM transactions are higher than card-present signature transactions but lower than card-not-present signature transactions. Counterfeit and lost and stolen are two major sources of fraudulent transactions. Lost and stolen is the number one reason for fraud in the card-present environment while counterfeit causes more fraud in the cardnot-present environment. Fraud rates are generally higher for merchant categories that have larger shares of signature card-not-present transactions and lower for merchant categories that have larger shares of PIN transactions, but these two shares do not completely explain the fraud rates of different merchant categories. Collecting data on payment card fraud in greater detail will help the industry identify risks and causes of fraud and effectively reduce fraud losses. 


\section{References}

Aite Group. 2012. The Contenders: Prepaid Debit and Payroll Cards Reach Ubiquity.

Federal Reserve Board. 2011. “2009 Interchange Revenue, Covered Issuer Cost, and Covered Issuer and Merchant Fraud Loss Related to Debit Card Transactions,” available at: http://www.federalreserve.gov/paymentsystems/files/debitfees_costs.pdf.

Federal Reserve Board. 2012. “Average Debit Card Interchange Fee by Payment Card Network,” available at: http://www.federalreserve.gov/paymentsystems/regii-average-interchangefee.htm.

Federal Reserve Board. 2013. “2011 Interchange Revenue, Covered Issuer Cost, and Covered Issuer and Merchant Fraud Loss Related to Debit Card Transactions,” available at: http://www.federalreserve.gov/paymentsystems/files/debitfees_costs_2011.pdf.

Federal Reserve System. 2011. The 2010 Federal Reserve Payments Study.

Gerdes, Geoffrey. 2011. "Volumes and Trends in Prepaid from the Federal Reserve Payments Study,” Presentation made at the 29 ${ }^{\text {th }}$ Annual ATM, Debit, and Prepaid Forum 2011.

Government Accountability Office. 2013. Automated Teller Machines: Some Consumer Fees Have Increased. April.

Rhine, Sherrie, Katy Jacob, Yazmin Osaki, and Jennifer Tescher. 2007. "Cardholders Use of General Spending Prepaid Cards: A Closer Look at the Market,” Center for Financial Services Innovation.

Sullivan, Richard. 2009. "The Benefits of Collecting and Reporting Payment Fraud Statistics for the United States,” Federal Reserve Bank of Kansas City Payments System Research Briefing, October.

Wilshusen, Stephanie, Robert Hunt, James van Ostal, and Rachel Schnider. 2012. “Consumers’ Use of Prepaid Cards: A Transaction-Based Analysis,” Federal Reserve Bank of Philadelphia Payment Card Center Discussion Paper, August. 


\section{Table 2.1: Summary Statistics_Account Characteristics}

\begin{tabular}{|l|l|c|}
\hline \multicolumn{2}{|l|}{} & Share (\%) \\
\hline \multirow{4}{*}{ Load type } & Never reload & 17.7 \\
\cline { 2 - 3 } & Occasional reload & 13.4 \\
\cline { 2 - 3 } & Periodic self-funded & 45.8 \\
\cline { 2 - 3 } & Periodic government direct deposit & 6.5 \\
\cline { 2 - 3 } & Periodic non-government direct deposit & 18.6 \\
\hline \multirow{3}{*}{$\begin{array}{l}\text { Fee program } \\
\text { type }\end{array}$} & Per transaction & 76.8 \\
\cline { 2 - 3 } type & Monthly & 23.2 \\
\hline \multirow{5}{*}{$\begin{array}{l}\text { Sistributor } \\
\text { Service }\end{array}$} & Check casher & 60.1 \\
\cline { 2 - 3 } & Direct & 21.9 \\
\cline { 2 - 3 } & Retail & 10.0 \\
\cline { 2 - 3 } & Disbursement & 6.2 \\
\cline { 2 - 3 } & Tax & 0.7 \\
\cline { 2 - 3 } & Other & 1.1 \\
\cline { 2 - 3 } & Alert & 48.7 \\
\cline { 2 - 3 } & Email & 57.5 \\
\cline { 2 - 3 } & Customer service call & 93.3 \\
\cline { 2 - 3 } & Web & 60.9 \\
\hline & Overdraft & 5.1 \\
\cline { 2 - 3 } & Overdraft buffer & 49.7 \\
\hline
\end{tabular}


Figure 3.1: Number of Active Cards per 10,000 People by County in 2011

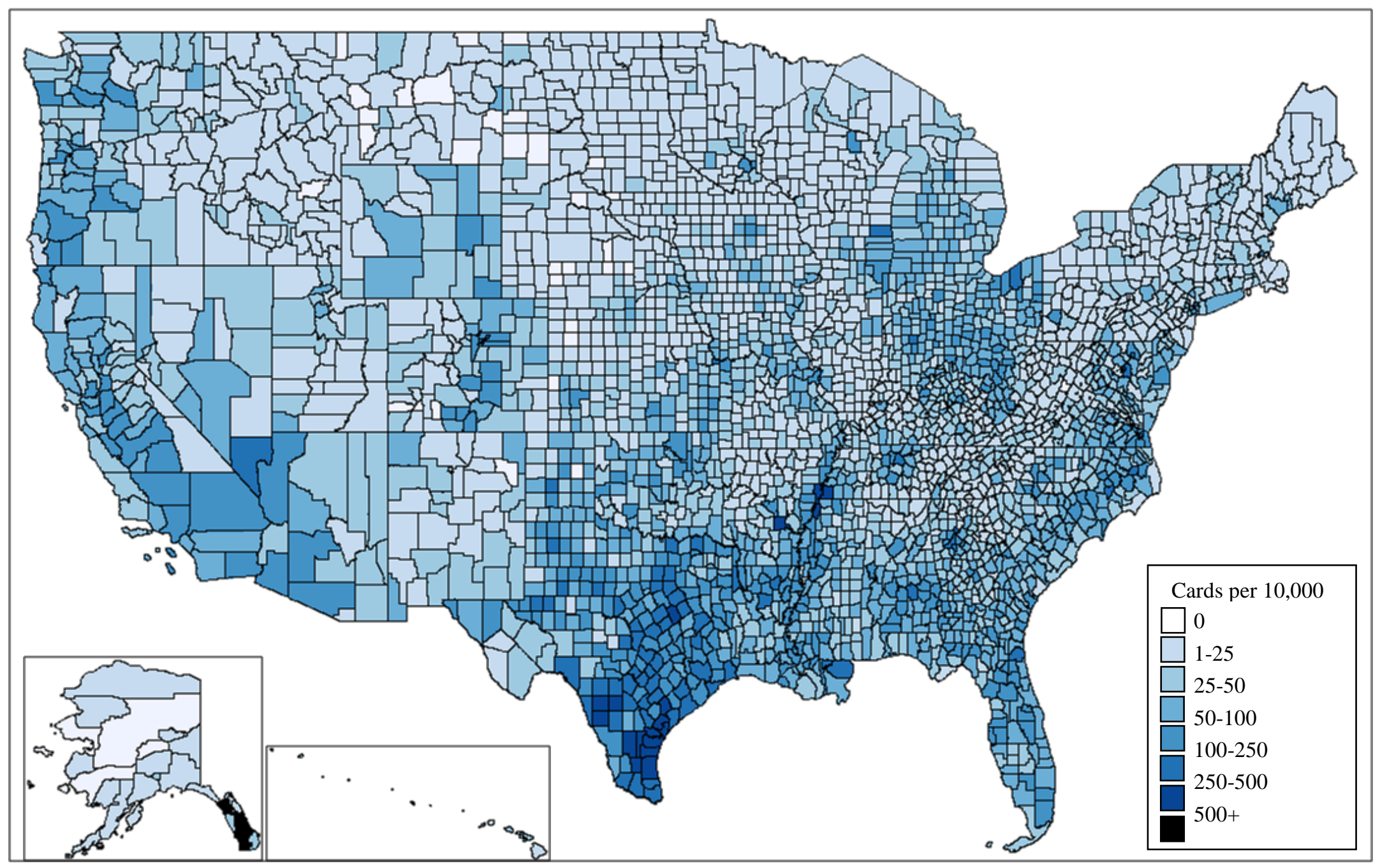

This map is based on county population as reported in the 2011 5-Year American Community Survey. 
Table 3.1: Regression Results for the Number of Cards per 10,000 Residents

\begin{tabular}{|c|c|c|c|c|c|}
\hline & Female & $\begin{array}{l}1.786^{* *} \\
(0.750)\end{array}$ & \multirow{9}{*}{ Income } & Less than $\$ 10,000$ & $\begin{array}{l}0.394 \\
(0.743)\end{array}$ \\
\hline \multirow{7}{*}{ Race } & Black & $\begin{array}{l}-0.154 \\
(0.195)\end{array}$ & & $\$ 10,000-\$ 15,000$ & $\begin{array}{l}-1.237 \\
(0.875)\end{array}$ \\
\hline & American Indian & $\begin{array}{l}-1.808^{* * *} \\
(0.265)\end{array}$ & & $\$ 15,000-\$ 25,000$ & $\begin{array}{l}-0.573 \\
(0.706)\end{array}$ \\
\hline & Asian & $\begin{array}{l}-0.427 \\
(0.657)\end{array}$ & & $\$ 25,000-\$ 35,000$ & $\begin{array}{l}-1.021 \\
(0.820)\end{array}$ \\
\hline & Hawaiian & $\begin{array}{l}-6.278^{*} \\
(3.673)\end{array}$ & & $\$ 50,000-\$ 75,000$ & $\begin{array}{l}1.278^{*} \\
(0.693)\end{array}$ \\
\hline & Other & $\begin{array}{l}-3.343^{* * *} \\
(0.484)\end{array}$ & & $\$ 75,000-\$ 100,000$ & $\begin{array}{l}0.364 \\
(0.744)\end{array}$ \\
\hline & Multiple race & $\begin{array}{l}0.060 \\
(0.703) \\
\end{array}$ & & $\$ 100,000-\$ 150,000$ & $\begin{array}{l}0.215 \\
(0.722)\end{array}$ \\
\hline & Hispanic & $\begin{array}{l}2.914^{* * *} \\
(0.174) \\
\end{array}$ & & $\$ 150,000-\$ 200,000$ & $\begin{array}{l}1.171 \\
(1.344)\end{array}$ \\
\hline \multirow{6}{*}{ Age } & 15 and under & $\begin{array}{l}-1.680 \\
(1.157)\end{array}$ & & More than $\$ 200,000$ & $\begin{array}{l}2.110^{*} \\
(1.196) \\
\end{array}$ \\
\hline & 15 to 24 & $\begin{array}{l}-1.528^{*} \\
(0.845)\end{array}$ & \multirow{4}{*}{$\begin{array}{l}\text { Federal direct payments } \\
\text { to individuals }\end{array}$} & For retirement and disability & $\begin{array}{l}-3.739^{* *} \\
(1.461)\end{array}$ \\
\hline & 35 to 44 & $\begin{array}{l}-3.353^{* * *} \\
(1.288)\end{array}$ & & For others & $\begin{array}{l}5.267^{* * *} \\
(1.645) \\
\end{array}$ \\
\hline & 45 to 55 & $\begin{array}{l}1.048 \\
(1.166)\end{array}$ & & Poverty & $\begin{array}{l}0.771 \\
(0.493)\end{array}$ \\
\hline & 55 to 64 & $\begin{array}{l}-2.819^{* *} \\
(1.125)\end{array}$ & & Unemployment & $\begin{array}{l}-1.548^{* * *} \\
(0.483)\end{array}$ \\
\hline & 65 and over & $\begin{array}{l}0.824 \\
(0.874)\end{array}$ & \multirow{3}{*}{ Family households } & Married couple & $\begin{array}{l}-2.715^{* * *} \\
(1.027)\end{array}$ \\
\hline \multirow{6}{*}{ Education } & Less than 9th grade & $\begin{array}{l}-1.703^{* * *} \\
(0.501)\end{array}$ & & Male hous eholder & $\begin{array}{l}-0.145 \\
(2.594)\end{array}$ \\
\hline & Less than 12 th grade & $\begin{array}{l}-0.751 \\
(0.631)\end{array}$ & & Female householder & $\begin{array}{l}4.438^{* * *} \\
(1.314) \\
\end{array}$ \\
\hline & Some college & $\begin{array}{l}1.069^{* * *} \\
(0.378)\end{array}$ & \multirow{2}{*}{ Non-family households } & Male hous eholder & $\begin{array}{l}-1.874 \\
(1.461)\end{array}$ \\
\hline & Associate's degree & $\begin{array}{l}-1.366^{* *} \\
(0.590)\end{array}$ & & Female householder & $\begin{array}{l}-3.136^{* *} \\
(1.312) \\
\end{array}$ \\
\hline & Bachelor's degree & $\begin{array}{l}0.456 \\
(0.491)\end{array}$ & \multirow{2}{*}{$\begin{array}{l}\text { Crime incidents per } \\
10,000 \text { residents }\end{array}$} & Violent & $\begin{array}{l}0.121^{*} \\
(0.066)\end{array}$ \\
\hline & Graduate degree & $\begin{array}{l}-2.839^{* * *} \\
(0.673)\end{array}$ & & Property & $\begin{array}{l}0.067^{* * *} \\
(0.012)\end{array}$ \\
\hline \multirow{2}{*}{ Access to banking } & Unbanked & $\begin{array}{l}1.848^{* * *} \\
(0.651)\end{array}$ & & Constant & $\begin{array}{l}162.660 \\
(126.129)\end{array}$ \\
\hline & Underbanked & $\begin{array}{l}1.441^{* * *} \\
(0.440)\end{array}$ & & $\begin{array}{l}\text { Observations } \\
\text { Adjusted R-squared }\end{array}$ & $\begin{array}{l}3,136 \\
0.416\end{array}$ \\
\hline
\end{tabular}

Notes: Standard errors are shown in parentheses. Federal direct payments to individuals, poverty and unemployment rates, crime incidents per 10,000 residents, and access to banking variables are continuous, and the other variables are dummy. Default race is White. Default age bracket is $25-34$. Default education is High School. Default income bracket is $\$ 35,000-\$ 50,000$.

$* * *, * *, *$ Significant at the $0.01,0.05$, and 0.10 level, respectively.

Sources: The authors' calculations using 2011 American Community Survey (sex, race, ethnicity, age, education, and income), 2010 US Census-Governments Division (federal direct payments to individuals), 2009 US Census-Small Area Income and Poverty Estimates (poverty), 2010 US Census (family and non-family households), 2011 Bureau of Labor Statistics-Current Population Survey (unemployment), 2010 FBI Uniform Crime Report (violent and property crime), and 2011 FDIC National Survey of Unbanked and Underbanked Households (access to banking). 


\section{Chart 4.1: Survival Rate - All Cards}

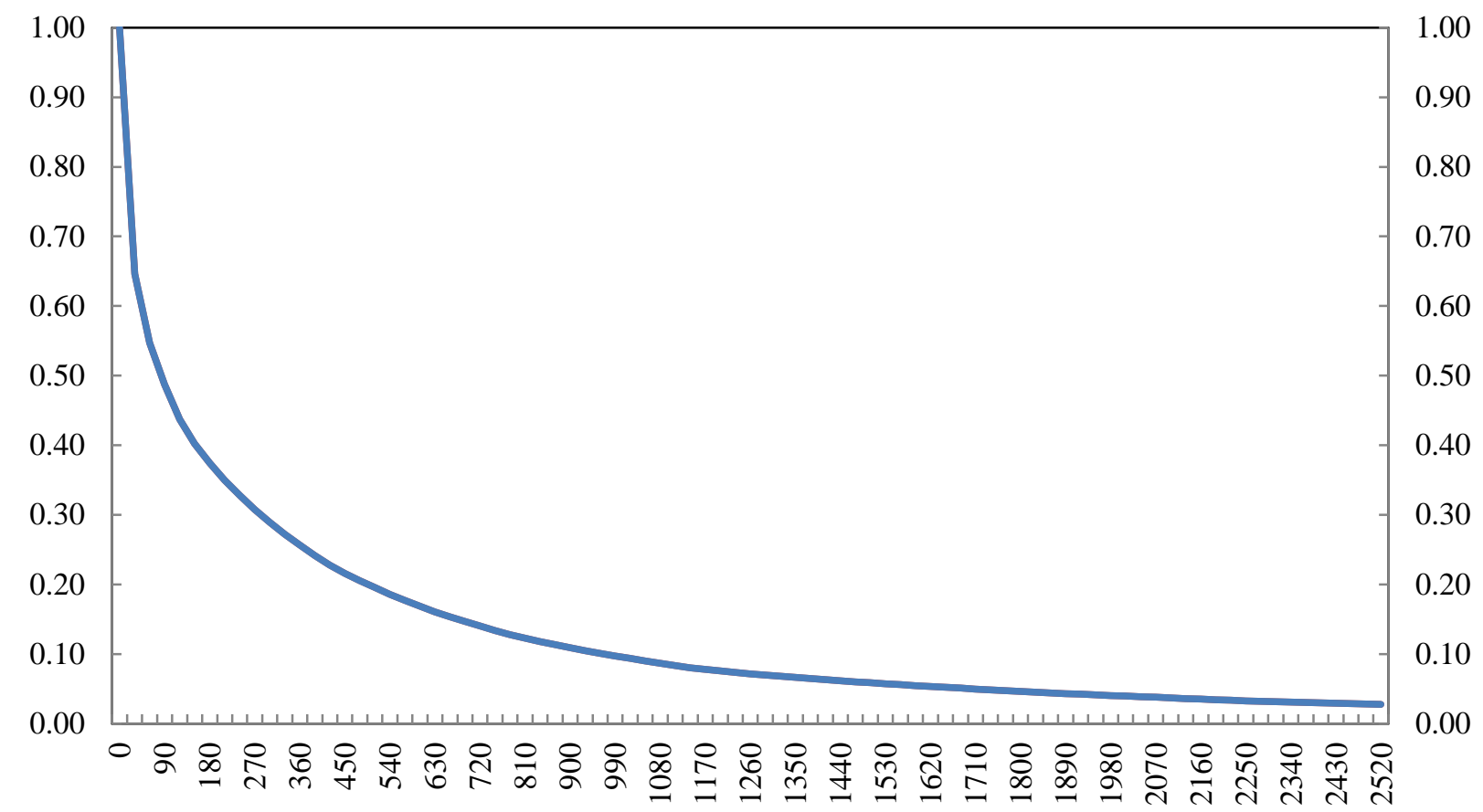

\section{Chart 4.2: Survival Rates - By Load Type}

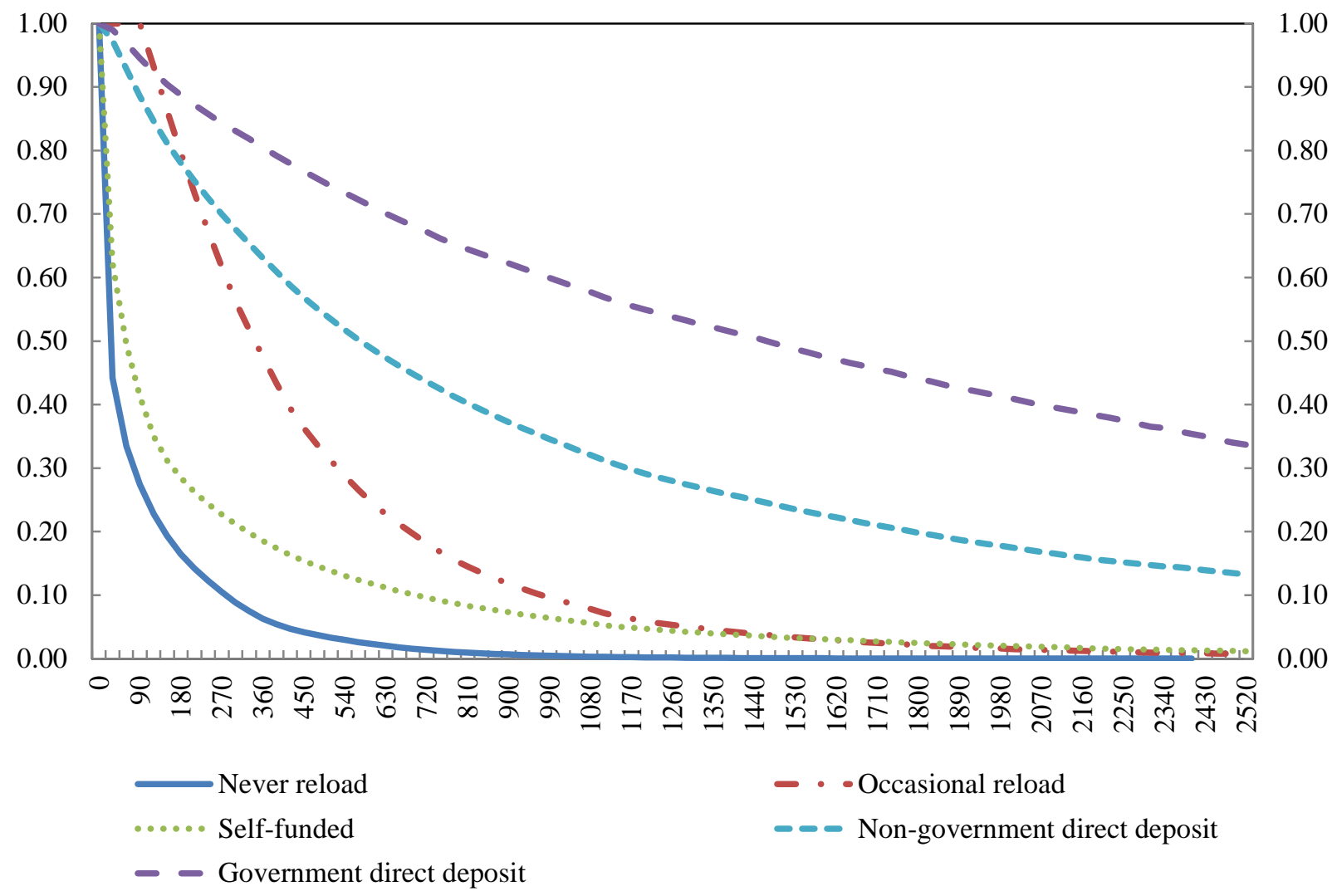




\section{Chart 4.3: Survival Rates - By Fee Program Type}

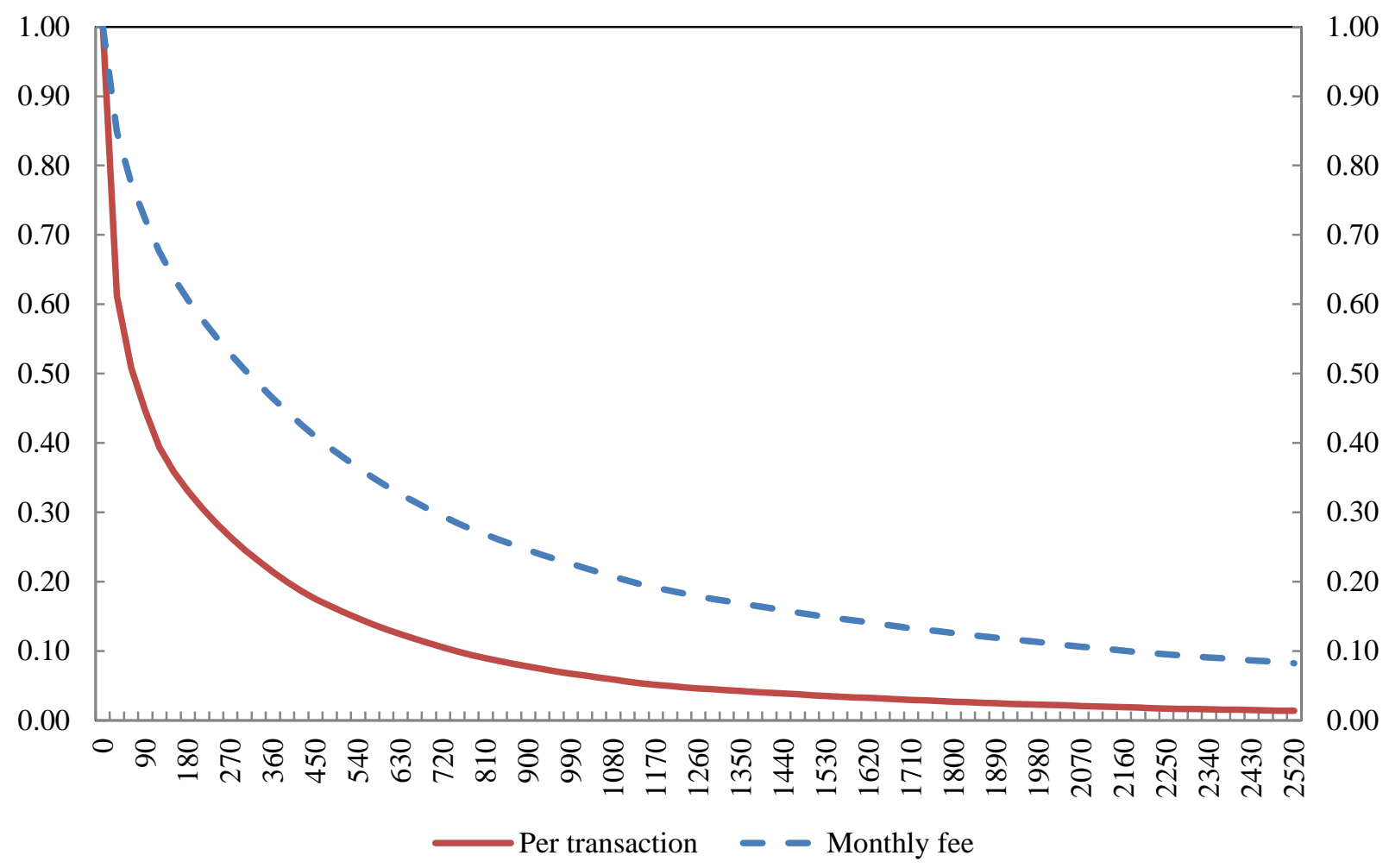

Table 4.1 Median and Mean Life Span (Days)

\begin{tabular}{|c|c|c|c|}
\hline & Median & Mean \\
\hline & All & 90 & 347 \\
\hline \multirow{5}{*}{ Load type } & Never reload & 30 & 111 \\
\hline & Occasional reload & 330 & 489 \\
\hline & Periodic self-funded & 60 & 256 \\
\hline & Periodic government direct deposit & 1440 & 1474 \\
\hline & Periodic non-government direct deposit & 570 & 925 \\
\hline \multirow{2}{*}{$\begin{array}{l}\text { Fee program } \\
\text { type }\end{array}$} & Per transaction & 60 & 278 \\
\hline & Monthly & 300 & 657 \\
\hline \multirow{6}{*}{$\begin{array}{l}\text { Distributor } \\
\text { type }\end{array}$} & Check casher & 60 & 326 \\
\hline & Direct & 240 & 503 \\
\hline & Retail & 60 & 331 \\
\hline & Disbursement & 30 & 169 \\
\hline & Tax & 30 & 169 \\
\hline & Other & 210 & 541 \\
\hline \multirow{6}{*}{$\begin{array}{l}\text { Service } \\
\text { utilized }\end{array}$} & Alert & 210 & 522 \\
\hline & Email & 150 & 447 \\
\hline & Customer service call & 90 & 355 \\
\hline & Web & 180 & 475 \\
\hline & Overdraft & 990 & 1284 \\
\hline & Overdraft buffer & 330 & 608 \\
\hline
\end{tabular}


Table 4.2a: Hazards Model Results: Coefficients for Account Characteristics and Transaction Patterns

\begin{tabular}{|c|c|c|c|c|}
\hline \multicolumn{2}{|l|}{ Specification } & 1 & 1 & 2 \\
\hline \multicolumn{2}{|l|}{ Sample } & National & Texas & Texas \\
\hline \multirow{6}{*}{ Load type } & Never & $\begin{array}{c}0.667^{* * *} \\
(0.002)\end{array}$ & $\begin{array}{c}0.644^{* * *} \\
(0.005)\end{array}$ & $\begin{array}{l}0.639^{* * *} \\
(0.005)\end{array}$ \\
\hline & Occasionally & $-0.798^{* * *}$ & $-0.889^{* * *}$ & $-0.902^{* * *}$ \\
\hline & & $(0.002)$ & $(0.005)$ & $(0.005)$ \\
\hline & Government direct deposit & $-1.805^{* * *}$ & $-1.936^{* * *}$ & $-1.937^{* * *}$ \\
\hline & & $(0.006)$ & $(0.012)$ & $(0.012)$ \\
\hline & Non-government direct deposit & $\begin{array}{c}-0.863^{* * *} \\
(0.003)\end{array}$ & $\begin{array}{c}-0.971^{* * *} \\
(0.006)\end{array}$ & $\begin{array}{c}-0.977^{* * *} \\
(0.006)\end{array}$ \\
\hline Fee program type & Per transaction & $\begin{array}{l}0.281^{* * *} \\
(0.002)\end{array}$ & $\begin{array}{l}0.264^{* * *} \\
(0.005)\end{array}$ & $\begin{array}{l}0.262^{* * *} \\
(0.005)\end{array}$ \\
\hline \multirow{6}{*}{ Distributor type } & Direct & $\begin{array}{c}-0.288^{* * *} \\
(0.002)\end{array}$ & $\begin{array}{c}-0.343^{* * *} \\
(0.006)\end{array}$ & $\begin{array}{c}-0.334^{* * *} \\
(0.006)\end{array}$ \\
\hline & Retail & $\begin{array}{c}-0.124^{* * *} \\
(0.002)\end{array}$ & $\begin{array}{c}-0.505^{* * *} \\
(0.004)\end{array}$ & $\begin{array}{c}-0.472^{* * *} \\
(0.005)\end{array}$ \\
\hline & Disbursement & $\begin{array}{l}0.224^{* * *} \\
(0.003)\end{array}$ & $\begin{array}{l}0.280^{* * *} \\
(0.009)\end{array}$ & $\begin{array}{l}0.296^{* * *} \\
(0.009)\end{array}$ \\
\hline & Tax & $0.395^{* * *}$ & $0.327^{* * *}$ & $0.333^{* * *}$ \\
\hline & & $(0.007)$ & -0.033 & -0.033 \\
\hline & Other & $\begin{array}{c}-0.193^{* * *} \\
(0.007)\end{array}$ & $\begin{array}{c}-0.394^{* * *} \\
(0.013)\end{array}$ & $\begin{array}{c}-0.383^{* * *} \\
(0.013)\end{array}$ \\
\hline \multirow{4}{*}{ Overdraft status } & Overdraft & $-0.126^{* * *}$ & $-0.138^{* * *}$ & $-0.145^{* * *}$ \\
\hline & & $(0.006)$ & $(0.011)$ & $(0.011)$ \\
\hline & Overdraft buffer & $-1.179^{* * *}$ & $-1.252^{* * *}$ & $-1.252^{* * *}$ \\
\hline & & $(0.002)$ & $(0.004)$ & $(0.004)$ \\
\hline \multirow{10}{*}{ Service utilized } & Email & $\begin{array}{c}-0.216^{* * *} \\
(0.002)\end{array}$ & $\begin{array}{c}-0.240^{* * *} \\
(0.005)\end{array}$ & $\begin{array}{c}-0.243^{* * *} \\
(0.005)\end{array}$ \\
\hline & Customer service call & $-0.558^{* * *}$ & $-0.582^{* * *}$ & $-0.585^{* * *}$ \\
\hline & & $(0.003)$ & $(0.006)$ & $(0.006)$ \\
\hline & Web & $-0.330^{* * *}$ & $-0.339^{* * *}$ & $-0.338^{* * *}$ \\
\hline & & $(0.002)$ & $(0.005)$ & $(0.005)$ \\
\hline & Alerts & $-0.274^{* * *}$ & $-0.318^{* * *}$ & $-0.320^{* * *}$ \\
\hline & & $(0.002)$ & $(0.004)$ & $(0.004)$ \\
\hline & Controls? & no & no & yes \\
\hline & Observations & $2,964,340$ & 616,908 & 616,839 \\
\hline & Log likelihood & $-28,041,091$ & $-5,041,635$ & $-5,040,321$ \\
\hline
\end{tabular}

Notes: Standard errors are shown in parentheses. Shares of value of total debits and average value of debits per month are continuous, and the other variables are dummy. The vector of controls includes zip-code level demographic characteristics.

$* * *, * *, *$ Significant at the $0.01,0.05$, and 0.10 level, respectively. 
Table 4.2b: Hazards Model Results: Coefficients for Zip-code Demographic Characteristics

\begin{tabular}{|c|c|c|c|c|c|}
\hline & Female & $\begin{array}{c}0.569^{* * *} \\
(0.089)\end{array}$ & \multirow{6}{*}{ Education } & Less than 9th grade & $\begin{array}{c}-0.295^{* * *} \\
(0.067)\end{array}$ \\
\hline \multirow{6}{*}{ Race } & Black & $\begin{array}{c}0.013 \\
(0.019)\end{array}$ & & Less than 12 th grade & $\begin{array}{c}0.085 \\
(0.105)\end{array}$ \\
\hline & American Indian & $\begin{array}{c}-1.638^{* * *} \\
(0.372)\end{array}$ & & Some college & $\begin{array}{c}0.014 \\
(0.084)\end{array}$ \\
\hline & Asian & $\begin{array}{l}0.239^{* * *} \\
(0.050)\end{array}$ & & Associate's degree & $\begin{array}{c}0.131 \\
(0.138)\end{array}$ \\
\hline & Hawaiian & $\begin{array}{c}1.136^{*} \\
(0.640)\end{array}$ & & Bachelor's degree & $\begin{array}{c}-0.067 \\
(0.075)\end{array}$ \\
\hline & Other & $\begin{array}{l}-0.019 \\
(0.028)\end{array}$ & & Graduate degree & $\begin{array}{c}-0.329^{* * *} \\
(0.094)\end{array}$ \\
\hline & Multiple race & $\begin{array}{c}0.253 \\
(0.159) \\
\end{array}$ & \multirow{9}{*}{ Income } & Less than $\$ 10,000$ & $\begin{array}{c}0.026 \\
(0.088)\end{array}$ \\
\hline & Hispanic & $\begin{array}{c}0.006 \\
(0.016) \\
\end{array}$ & & $\$ 10,000-\$ 15,000$ & $\begin{array}{c}-0.621^{* * *} \\
(0.125)\end{array}$ \\
\hline \multirow{6}{*}{ Age } & 15 and under & $\begin{array}{l}0.216^{*} \\
(0.119)\end{array}$ & & $\$ 15,000-\$ 25,000$ & $\begin{array}{c}-0.268^{* *} \\
(0.106)\end{array}$ \\
\hline & 15 to 24 & $\begin{array}{l}-0.132 \\
(0.091)\end{array}$ & & $\$ 25,000-\$ 35,000$ & $\begin{array}{c}0.189^{*} \\
(0.114)\end{array}$ \\
\hline & 35 to 44 & $\begin{array}{l}-0.128 \\
(0.149)\end{array}$ & & $\$ 50,000-\$ 75,000$ & $\begin{array}{l}-0.177 \\
(0.109)\end{array}$ \\
\hline & 45 to 54 & $\begin{array}{c}-0.354^{* * *} \\
(0.135)\end{array}$ & & $\$ 75,000-\$ 100,000$ & $\begin{array}{c}-0.384^{* * *} \\
(0.115)\end{array}$ \\
\hline & 55 to 64 & $\begin{array}{l}-0.249^{*} \\
(0.141)\end{array}$ & & $\$ 100,000-\$ 150,000$ & $\begin{array}{l}-0.041 \\
(0.105)\end{array}$ \\
\hline & 65 and over & $\begin{array}{r}0.054 \\
(0.130) \\
\end{array}$ & & $\$ 150,000-\$ 200,000$ & $\begin{array}{l}0.695^{* * *} \\
(0.174)\end{array}$ \\
\hline \multirow{5}{*}{ Marital status } & Married & $\begin{array}{c}-0.276^{* * *} \\
(0.070)\end{array}$ & & More than $\$ 200,000$ & $\begin{array}{l}-0.320^{* *} \\
(0.018)\end{array}$ \\
\hline & Widowed & $\begin{array}{c}-0.844^{* * *} \\
(0.200)\end{array}$ & \multirow{2}{*}{$\begin{array}{c}\text { Crime incidents } \\
\text { per } 10,000 \\
\text { residents }\end{array}$} & Violent & $\begin{array}{l}0.120^{* * *} \\
(0.014)\end{array}$ \\
\hline & Divorced & $\begin{array}{c}0.194 \\
(0.133)\end{array}$ & & Property & $\begin{array}{c}-0.003 \\
(0.002) \\
\end{array}$ \\
\hline & \multirow[t]{2}{*}{ Separated } & 0.202 & & Observations & 616,839 \\
\hline & & $(0.233)$ & & Log likelihood & $-5,040,321$ \\
\hline
\end{tabular}

Note: Standard errors are shown in parentheses. Crime incidents per 1,000 residents is continuous, and the other variables are dummy. Default race is White. Default age bracket is $25-34$. Default education is High School. Default income bracket is $\$ 35,000$ $\$ 50,000$.

$* * *, * *, *$ Significant at the $0.01,0.05$, and 0.10 level, respectively.

Sources: The authors' calculations using 2011 American Community Survey (sex, race, ethnicity, age, education, income, and marital status), 2010 FBI Uniform Crime Report (violent and property crime), and NetSpend. 
Table 4.3 Average Load and Debit Activities per Month

\begin{tabular}{|c|c|c|c|c|c|}
\hline \multirow{2}{*}{\multicolumn{2}{|c|}{ Account characteristics }} & \multicolumn{2}{|c|}{ Loads } & \multicolumn{2}{|c|}{ Debits } \\
\hline & & Number & $\begin{array}{l}\text { Value per } \\
\text { load (\$) }\end{array}$ & Number & $\begin{array}{l}\text { Value per } \\
\text { debit (\$) }\end{array}$ \\
\hline \multicolumn{2}{|l|}{ All } & 1.8 & 285.53 & 8.2 & 55.16 \\
\hline \multirow[t]{5}{*}{ Load type } & Never reload & 0.8 & 397.67 & 3.6 & 81.36 \\
\hline & Occasional reload & 0.5 & 288.73 & 2.3 & 57.19 \\
\hline & Periodic self-funded & 2.2 & 181.65 & 6.5 & 55.62 \\
\hline & Periodic government direct deposit & 2.1 & 477.78 & 12.5 & 61.48 \\
\hline & Periodic non-government direct deposit & 2.8 & 426.98 & 21.0 & 48.66 \\
\hline \multirow{2}{*}{$\begin{array}{l}\text { Fee program } \\
\text { type }\end{array}$} & Per transaction & 1.7 & 230.02 & 5.4 & 61.48 \\
\hline & Monthly & 2.3 & 418.66 & 17.6 & 48.68 \\
\hline \multirow{6}{*}{$\begin{array}{l}\text { Distributor } \\
\text { type }\end{array}$} & Check casher & 2.0 & 251.30 & 8.1 & 50.36 \\
\hline & Direct & 1.4 & 411.80 & 9.1 & 60.48 \\
\hline & Retail & 2.0 & 233.35 & 7.5 & 59.05 \\
\hline & Disbursement & 1.4 & 294.74 & 6.3 & 62.09 \\
\hline & Tax & 1.8 & $1,021.79$ & 14.9 & 119.33 \\
\hline & Other & 1.6 & 310.66 & 8.1 & 57.33 \\
\hline \multirow{6}{*}{$\begin{array}{l}\text { Service } \\
\text { utilized }\end{array}$} & Alert & 2.0 & 341.89 & 11.5 & 51.91 \\
\hline & Email & 1.8 & 355.11 & 10.4 & 56.25 \\
\hline & Customer service call & 1.8 & 292.73 & 8.5 & 54.74 \\
\hline & Web & 1.9 & 350.13 & 10.6 & 55.51 \\
\hline & Overdraft & 2.7 & 537.63 & 23.3 & 53.36 \\
\hline & Overdraft buffer & 1.9 & 341.05 & 11.2 & 51.16 \\
\hline
\end{tabular}


Table 4.4a: Results for Monthly Debits: Coefficients for Account Characteristics

\begin{tabular}{|c|c|c|c|c|c|c|c|}
\hline \multirow{2}{*}{ Specification } & & \multicolumn{3}{|c|}{ Volume of debits } & \multicolumn{3}{|c|}{ Value of debits (\$100) } \\
\hline & & 1 & 1 & 2 & 1 & 1 & 2 \\
\hline Sample & & National & Texas & Texas & National & Texas & Texas \\
\hline \multirow{4}{*}{ Load type } & Never & $\begin{array}{l}-2.312^{* * *} \\
(0.021)\end{array}$ & $\begin{array}{l}-2.452^{* * *} \\
(0.045)\end{array}$ & $\begin{array}{l}-2.473^{* * *} \\
(0.046)\end{array}$ & $\begin{array}{c}-0.839^{* * *} \\
(0.036)\end{array}$ & $\begin{array}{l}-1.196^{* * *} \\
(0.045)\end{array}$ & $\begin{array}{c}-1.214^{* * *} \\
(0.046)\end{array}$ \\
\hline & Occasionally & $\begin{array}{c}-5.237^{* * *} \\
(0.019)\end{array}$ & $\begin{array}{c}-5.421^{* * *} \\
(0.038)\end{array}$ & $\begin{array}{c}-5.374^{* * *} \\
(0.038)\end{array}$ & $\begin{array}{c}-3.035^{* * *} \\
(0.017)\end{array}$ & $\begin{array}{l}-2.714^{* * *} \\
(0.024)\end{array}$ & $\begin{array}{c}-2.693^{* * *} \\
(0.024)\end{array}$ \\
\hline & Government direct deposit & $\begin{array}{l}0.705^{* * *} \\
(0.050)\end{array}$ & $\begin{array}{l}0.906^{* * *} \\
(0.106)\end{array}$ & $\begin{array}{l}1.030^{* * *} \\
(0.103)\end{array}$ & $\begin{array}{l}0.542^{* * *} \\
(0.043)\end{array}$ & $\begin{array}{l}0.747^{* * *} \\
(0.070)\end{array}$ & $\begin{array}{l}0.830^{* * *} \\
(0.068)\end{array}$ \\
\hline & Non-government direct deposit & $\begin{array}{l}8.709^{* * *} \\
(0.048)\end{array}$ & $\begin{array}{c}10.600^{* * *} \\
(0.103)\end{array}$ & $\begin{array}{c}10.569^{* * *} \\
(0.102)\end{array}$ & $\begin{array}{l}3.132^{* * *} \\
(0.036)\end{array}$ & $\begin{array}{l}4.123^{* * *} \\
(0.054)\end{array}$ & $\begin{array}{l}4.105^{* * *} \\
(0.054)\end{array}$ \\
\hline $\begin{array}{l}\text { Fee program } \\
\text { type }\end{array}$ & Per transaction & $\begin{array}{c}-6.669^{* * *} \\
(0.036) \\
\end{array}$ & $\begin{array}{l}-8.053^{* * *} \\
(0.073)\end{array}$ & $\begin{array}{c}-7.939^{* * *} \\
(0.073) \\
\end{array}$ & $\begin{array}{l}-2.450^{* * *} \\
(0.017) \\
\end{array}$ & $\begin{array}{l}-2.744^{* * *} \\
(0.034) \\
\end{array}$ & $\begin{array}{l}-2.681^{* * *} \\
(0.033)\end{array}$ \\
\hline \multirow{5}{*}{ Distributor type } & Direct & $\begin{array}{l}-1.222^{* * *} \\
(0.027)\end{array}$ & $\begin{array}{l}-1.266^{* * *} \\
(0.060)\end{array}$ & $\begin{array}{c}-1.232^{* * *} \\
(0.058)\end{array}$ & $\begin{array}{l}0.009^{* * *} \\
(0.024)\end{array}$ & $\begin{array}{c}-0.143^{* * *} \\
(0.037)\end{array}$ & $\begin{array}{c}-0.130^{* * *} \\
(0.038)\end{array}$ \\
\hline & Retail & $\begin{array}{l}0.927^{* * *} \\
(0.032)\end{array}$ & $\begin{array}{l}0.896^{* * *} \\
(0.069)\end{array}$ & $\begin{array}{l}0.973^{* * *} \\
(0.063)\end{array}$ & $\begin{array}{l}0.787^{* * *} \\
(0.023)\end{array}$ & $\begin{array}{l}0.825^{* * *} \\
(0.042)\end{array}$ & $\begin{array}{l}0.915^{* * *} \\
(0.049)\end{array}$ \\
\hline & Disbursement & $\begin{array}{l}1.299^{* * *} \\
(0.032)\end{array}$ & $\begin{array}{l}2.098^{* * *} \\
(0.085)\end{array}$ & $\begin{array}{l}1.976^{* * *} \\
(0.086)\end{array}$ & $\begin{array}{l}0.522^{* * *} \\
(0.041)\end{array}$ & $\begin{array}{l}1.537^{* * *} \\
(0.070)\end{array}$ & $\begin{array}{l}1.470^{* * *} \\
(0.069)\end{array}$ \\
\hline & Tax & $\begin{array}{l}8.571^{* * *} \\
(0.109)\end{array}$ & $\begin{array}{l}8.788^{* * *} \\
(0.462)\end{array}$ & $\begin{array}{l}8.556^{* * *} \\
-0.475\end{array}$ & $\begin{array}{c}13.320^{* * *} \\
(0.162)\end{array}$ & $\begin{array}{c}13.520^{* * *} \\
(0.678)\end{array}$ & $\begin{array}{c}13.372^{* * *} \\
(0.681)\end{array}$ \\
\hline & Other & $\begin{array}{c}-2.419^{* * *} \\
(0.066) \\
\end{array}$ & $\begin{array}{c}-2.303^{* * *} \\
(0.142) \\
\end{array}$ & $\begin{array}{c}-2.217^{* * *} \\
-0.153 \\
\end{array}$ & $\begin{array}{c}-0.521^{* * *} \\
(0.049) \\
\end{array}$ & $\begin{array}{c}-0.659^{* * *} \\
(0.084) \\
\end{array}$ & $\begin{array}{c}-0.614^{* * *} \\
(0.084)\end{array}$ \\
\hline \multirow{2}{*}{ Overdraft status } & Overdraft & $\begin{array}{l}4.461^{* * *} \\
(0.055)\end{array}$ & $\begin{array}{l}3.764^{* * *} \\
(0.115)\end{array}$ & $\begin{array}{c}3.768^{* * *} \\
-0.113\end{array}$ & $\begin{array}{l}2.951^{* * *} \\
(0.032)\end{array}$ & $\begin{array}{l}3.094^{* * *} \\
(0.065)\end{array}$ & $\begin{array}{l}3.092^{* * *} \\
(0.063)\end{array}$ \\
\hline & Overdraft buffer & $\begin{array}{l}1.301^{* * *} \\
(0.018)\end{array}$ & $\begin{array}{l}1.152^{* * *} \\
(0.040)\end{array}$ & $\begin{array}{l}1.181^{* * *} \\
(0.040)\end{array}$ & $\begin{array}{l}0.008^{* * *} \\
(0.017)\end{array}$ & $\begin{array}{l}0.207^{* * *} \\
(0.024) \\
\end{array}$ & $\begin{array}{l}0.225^{* * *} \\
(0.023)\end{array}$ \\
\hline \multirow{4}{*}{ Service utilized } & Email & $\begin{array}{l}0.465^{* * *} \\
(0.018)\end{array}$ & $\begin{array}{l}0.473^{* * *} \\
(0.042)\end{array}$ & $\begin{array}{l}0.341^{* * *} \\
(0.040)\end{array}$ & $\begin{array}{l}0.627^{* * *} \\
(0.018)\end{array}$ & $\begin{array}{l}0.426^{* * *} \\
(0.026)\end{array}$ & $\begin{array}{l}0.356^{* * *} \\
(0.025)\end{array}$ \\
\hline & Customer service call & $\begin{array}{l}1.487^{* * *} \\
(0.019)\end{array}$ & $\begin{array}{l}1.416^{* * *} \\
(0.042)\end{array}$ & $\begin{array}{l}1.530^{* * *} \\
(0.044)\end{array}$ & $\begin{array}{l}0.751^{* * *} \\
(0.027)\end{array}$ & $\begin{array}{l}0.378^{* * *} \\
(0.053)\end{array}$ & $\begin{array}{l}0.437^{* * *} \\
(0.053)\end{array}$ \\
\hline & Web & $\begin{array}{l}1.293^{* * *} \\
(0.017)\end{array}$ & $\begin{array}{l}1.396^{* * *} \\
(0.040)\end{array}$ & $\begin{array}{l}1.322^{* * *} \\
(0.041)\end{array}$ & $\begin{array}{l}1.020^{* * *} \\
(0.018)\end{array}$ & $\begin{array}{l}0.827^{* * *} \\
(0.027)\end{array}$ & $\begin{array}{l}0.790^{* * *} \\
(0.027)\end{array}$ \\
\hline & Alerts & $\begin{array}{l}0.897^{* * *} \\
(0.0150) \\
\end{array}$ & $\begin{array}{l}1.155^{* * *} \\
(0.030) \\
\end{array}$ & $\begin{array}{l}1.177^{* * *} \\
(0.030) \\
\end{array}$ & $\begin{array}{l}0.205^{* * *} \\
(0.017) \\
\end{array}$ & $\begin{array}{l}0.530^{* * *} \\
(0.022) \\
\end{array}$ & $\begin{array}{l}0.536^{* * *} \\
(0.022) \\
\end{array}$ \\
\hline \multirow{3}{*}{$\begin{array}{l}\text { Share of value of } \\
\text { total debits }\end{array}$} & Cash withdrawals & $\begin{array}{l}1.143^{* * *} \\
(0.042)\end{array}$ & $\begin{array}{l}0.165^{* *} \\
(0.073)\end{array}$ & $\begin{array}{l}0.369^{* * *} \\
(0.071)\end{array}$ & $\begin{array}{l}3.964^{* * *} \\
(0.072)\end{array}$ & $\begin{array}{l}2.758^{* * *} \\
(0.056)\end{array}$ & $\begin{array}{l}2.845^{* * *} \\
(0.054)\end{array}$ \\
\hline & Bill payments & $\begin{array}{c}14.305^{* * *} \\
(0.741)\end{array}$ & $\begin{array}{c}16.443^{* * *} \\
(2.267)\end{array}$ & $\begin{array}{c}15.590^{* * *} \\
(2.238)\end{array}$ & $\begin{array}{c}18.440^{* * *} \\
(0.661)\end{array}$ & $\begin{array}{c}19.130^{* * *} \\
(1.666)\end{array}$ & $\begin{array}{c}18.607^{* * *} \\
(1.644)\end{array}$ \\
\hline & Person-to-person transfers & $\begin{array}{c}-0.913^{* * *} \\
(0.088)\end{array}$ & $\begin{array}{c}-2.599^{* * *} \\
(0.191)\end{array}$ & $\begin{array}{c}-2.638^{* * *} \\
(0.192)\end{array}$ & $\begin{array}{l}7.721^{* * *} \\
(0.126)\end{array}$ & $\begin{array}{l}5.919^{* * *} \\
(0.203)\end{array}$ & $\begin{array}{l}5.890^{* * *} \\
(0.203)\end{array}$ \\
\hline & Constant & $\begin{array}{l}9.083^{* * *} \\
(0.041)\end{array}$ & $\begin{array}{c}10.313^{* * *} \\
(0.085)\end{array}$ & $\begin{array}{c}12.058^{* * *} \\
(1.593)\end{array}$ & $\begin{array}{l}3.376^{* * *} \\
(0.032)\end{array}$ & $\begin{array}{l}3.808^{* * *} \\
(0.064)\end{array}$ & $\begin{array}{c}0.290 \\
(1.290)\end{array}$ \\
\hline & Controls? & no & no & yes & no & no & yes \\
\hline & Observations & 2,926,222 & 608,757 & 608,757 & $2,926,222$ & 608,757 & 608,757 \\
\hline & Adjusted R-squared & 0.373 & 0.410 & 0.414 & 0.230 & 0.301 & 0.305 \\
\hline
\end{tabular}

Notes: Standard errors are shown in parentheses. Shares of value of total debits and average value of debits per month are continuous, and the other variables are dummy. The vector of controls includes zip-code level demographic characteristics.

$* * *, * *, *$ Significant at the $0.01,0.05$, and 0.10 level, respectively. 
Table 4.4b: Results for Monthly Debits: Coefficients for Zip-code level Demographics

\begin{tabular}{|c|c|c|c|c|c|c|c|}
\hline & & & & & & \multirow[b]{2}{*}{ Volume } & \multirow[b]{2}{*}{$\begin{array}{c}\text { Value } \\
(\$ 100) \\
\end{array}$} \\
\hline & & Volume & $\begin{array}{c}\text { Value } \\
(\$ 100)\end{array}$ & & & & \\
\hline & Female & $\begin{array}{l}3.460^{* *} \\
(1.367) \\
\end{array}$ & $\begin{array}{l}1.925^{* *} \\
(0.876)\end{array}$ & \multirow{10}{*}{ Education } & Less than 9th grade & $\begin{array}{l}-0.422 \\
(1.331)\end{array}$ & $\begin{array}{c}0.598 \\
(0.976)\end{array}$ \\
\hline \multirow{10}{*}{ Race } & Black & $\begin{array}{c}-2.802^{* * *} \\
(0.322)\end{array}$ & $\begin{array}{c}-0.595^{* * *} \\
(0.221)\end{array}$ & & Less than 12 th grade & $\begin{array}{l}3.184^{* *} \\
(1.465)\end{array}$ & $\begin{array}{l}2.971^{* * *} \\
(1.023)\end{array}$ \\
\hline & American Indian & -6.735 & -4.180 & & Some college & 1.696 & 0.874 \\
\hline & & $(4.704)$ & (3.599) & & & $(1.393)$ & $(0.965)$ \\
\hline & \multirow[t]{2}{*}{ Asian } & -1.247 & 0.114 & & \multirow[t]{2}{*}{ Associate's degree } & $-6.328^{* * *}$ & $-4.204^{* * *}$ \\
\hline & & $(0.786)$ & $(0.557)$ & & & $(1.947)$ & $(1.441)$ \\
\hline & \multirow[t]{2}{*}{ Hawaiian } & -1.467 & -4.985 & & \multirow[t]{2}{*}{ Bachelor's degree } & -0.255 & -0.782 \\
\hline & & $(10.452)$ & (5.434) & & & $(1.145)$ & $(0.799)$ \\
\hline & \multirow[t]{2}{*}{ Other } & 0.261 & -0.165 & & \multirow[t]{2}{*}{ Graduate degree } & $-4.662^{* * *}$ & -1.594 \\
\hline & & $(0.402)$ & $(0.266)$ & & & $(1.500)$ & $(1.052)$ \\
\hline & Multiple race & $\begin{array}{c}0.745 \\
(2.408) \\
\end{array}$ & $\begin{array}{l}-1.450 \\
(1.596)\end{array}$ & & Less than $\$ 10,000$ & $\begin{array}{c}-1.332 \\
(1.262)\end{array}$ & $\begin{array}{c}0.203 \\
(0.911)\end{array}$ \\
\hline & Hispanic & $\begin{array}{c}-2.265^{* * *} \\
(0.305)\end{array}$ & $\begin{array}{c}-1.146^{* * *} \\
(0.222)\end{array}$ & & $\$ 10,000-\$ 15,000$ & $\begin{array}{c}0.627 \\
(1.867)\end{array}$ & $\begin{array}{l}-0.018 \\
(1.344)\end{array}$ \\
\hline & 15 and under & $\begin{array}{l}-3.761^{*} \\
(1.943)\end{array}$ & $\begin{array}{c}-2.966^{* *} \\
(1.311)\end{array}$ & & $\$ 15,000-\$ 25,000$ & $\begin{array}{l}-1.860 \\
(1.368)\end{array}$ & $\begin{array}{c}-1.070 \\
(1.097)\end{array}$ \\
\hline & \multirow[t]{2}{*}{15 to 24} & -1.473 & 0.166 & & \multirow[t]{2}{*}{$\$ 25,000-\$ 35,000$} & -1.500 & -1.304 \\
\hline & & $(1.275)$ & $(0.860)$ & & & $(1.801)$ & $(1.297)$ \\
\hline & \multirow[t]{2}{*}{35 to 44} & -1.192 & 1.843 & Income & \multirow[t]{2}{*}{$\$ 50,000-\$ 75,000$} & 1.944 & 1.322 \\
\hline \multirow{4}{*}{ Age } & & $(2.479)$ & $(1.592)$ & & & $(1.548)$ & $(1.108)$ \\
\hline & 45 to 54 & $\begin{array}{c}-8.239^{* * *} \\
(2.328)\end{array}$ & $\begin{array}{l}-4.414^{* *} \\
(1.614)\end{array}$ & & $\$ 75,000-\$ 100,000$ & $\begin{array}{c}2.580 \\
(1.799)\end{array}$ & $\begin{array}{c}1.824 \\
(1.322)\end{array}$ \\
\hline & 55 to 64 & -1.659 & $\begin{array}{l}-1.923 \\
(1.443)\end{array}$ & & $\$ 100,000-\$ 150,000$ & $\begin{array}{l}4.370^{* * *} \\
(1675)\end{array}$ & $\begin{array}{l}2.450^{* *} \\
(1205)\end{array}$ \\
\hline & 65 and over & $\begin{array}{l}-2.964 \\
(1.956) \\
\end{array}$ & $\begin{array}{c}-2.685^{* *} \\
(1.309) \\
\end{array}$ & & $\$ 150,000-\$ 200,000$ & $\begin{array}{l}5.890^{* *} \\
(2.666)\end{array}$ & $\begin{array}{c}2.745 \\
(1.205)\end{array}$ \\
\hline \multirow{4}{*}{$\begin{array}{c}\text { Marital } \\
\text { status }\end{array}$} & Married & $\begin{array}{l}-1.079 \\
(1.016)\end{array}$ & $\begin{array}{c}2.063^{* * *} \\
(0.715)\end{array}$ & & More than $\$ 200,000$ & $\begin{array}{l}3.938^{* *} \\
(1.913) \\
\end{array}$ & $\begin{array}{l}2.745^{* * *} \\
(1.861) \\
\end{array}$ \\
\hline & Widowed & $\begin{array}{l}-4.867^{*} \\
(2.902)\end{array}$ & $\begin{array}{c}1.273 \\
(2.032)\end{array}$ & $\begin{array}{c}\text { Crime } \\
\text { incidents }\end{array}$ & Violent & $\begin{array}{l}-0.627^{* *} \\
(0.276)\end{array}$ & $\begin{array}{l}-0.067 \\
(0.195)\end{array}$ \\
\hline & Divorced & $\begin{array}{c}3.180 \\
(1.970)\end{array}$ & $\begin{array}{c}2.396^{*} \\
(1.371)\end{array}$ & $\begin{array}{l}\text { per } 10,000 \\
\text { residents }\end{array}$ & Property & $\begin{array}{l}0.096^{* * *} \\
(0.035)\end{array}$ & $\begin{array}{l}-0.026 \\
(0.024) \\
\end{array}$ \\
\hline & Separated & $\begin{array}{c}6.342^{*} \\
(3.843)\end{array}$ & $\begin{array}{c}2.863 \\
(2.740)\end{array}$ & & $\begin{array}{l}\text { Observations } \\
\text { Adjusted R-squared }\end{array}$ & $\begin{array}{c}608,757 \\
0.414\end{array}$ & $\begin{array}{c}608,757 \\
0.305\end{array}$ \\
\hline
\end{tabular}

Note: Standard errors are shown in parentheses. Crime incidents per 1,000 residents is continuous, and the other variables are dummy. Default race is White. Default age bracket is $25-34$. Default education is High School. Default income bracket is $\$ 35,000-\$ 50,000$.

***, **, * Significant at the 0.01, 0.05, and 0.10 level, respectively.

Sources: The authors' calculations using 2011 American Community Survey (sex, race, ethnicity, age, education, income, and marital status), 2010 FBI Uniform Crime Report (violent and property crime), and NetSpend. 


\section{Table 4.5 Four Types of Debit Transactions}

\begin{tabular}{|l|c|c|c|c|c|c|}
\hline \multirow{2}{*}{$\begin{array}{l}\text { Percent of } \\
\text { accounts }\end{array}$} & \multicolumn{4}{|c|}{ Share of transactions (\%) } & Average value \\
\cline { 3 - 6 } & used for: & \multicolumn{2}{|c|}{ All accounts } & \multicolumn{2}{c|}{ Among users } & ver transaction \\
\cline { 3 - 6 } & Volume & Value & Volume & Value & $(\$)$ \\
\hline Purchase & 97.1 & 87.7 & 79.7 & 89.1 & 81.0 & 52.07 \\
\hline ATM & 50.1 & 11.6 & 18.9 & 22.9 & 37.1 & 107.99 \\
\hline Bill payment & 0.8 & 0.0 & 0.1 & 2.8 & 7.4 & 322.10 \\
\hline Person-to-Person & 9.7 & 0.7 & 1.4 & 7.0 & 14.0 & 244.92 \\
\hline
\end{tabular}

\section{Table 4.6: Percent of Users of Four Types of Debit}

\begin{tabular}{|c|c|c|c|c|c|}
\hline \multirow{2}{*}{\multicolumn{2}{|c|}{ Account characteristics }} & \multicolumn{4}{|c|}{ Percent of accounts used for } \\
\hline & & \multirow{2}{*}{$\begin{array}{c}\text { Purchase } \\
97.1\end{array}$} & \multirow{2}{*}{$\begin{array}{l}\text { ATM } \\
50.1 \\
\end{array}$} & \multirow{2}{*}{$\begin{array}{c}\begin{array}{c}\text { Bill } \\
\text { payment }\end{array} \\
0.8\end{array}$} & \multirow{2}{*}{$\begin{array}{c}\begin{array}{c}\text { Person- } \\
\text { to-Person }\end{array} \\
9.7 \\
\end{array}$} \\
\hline All & & & & & \\
\hline \multirow[t]{5}{*}{ Load type } & Never reload & 95.2 & 26.9 & 0.0 & 1.4 \\
\hline & Occasional reload & 99.1 & 51.8 & 0.2 & 6.8 \\
\hline & Periodic self-funded & 96.6 & 38.6 & 0.1 & 5.3 \\
\hline & Periodic government direct deposit & 96.7 & 92.5 & 2.4 & 28.7 \\
\hline & Periodic non-government direct deposit & 99.1 & 90.5 & 3.3 & 26.5 \\
\hline \multirow{2}{*}{$\begin{array}{l}\text { Fee program } \\
\text { type }\end{array}$} & Per transaction & 96.6 & 41.4 & 0.1 & 5.5 \\
\hline & Monthly & 98.9 & 79.4 & 2.9 & 24.0 \\
\hline \multirow{6}{*}{$\begin{array}{l}\text { Distributor } \\
\text { type }\end{array}$} & Check casher & 97.3 & 47.7 & 0.5 & 9.2 \\
\hline & Direct & 97.6 & 62.0 & 1.9 & 14.8 \\
\hline & Retail & 96.9 & 37.1 & 0.3 & 6.4 \\
\hline & Disbursement & 94.1 & 47.4 & 0.3 & 2.9 \\
\hline & Tax & 95.4 & 86.1 & 0.1 & 3.1 \\
\hline & Other & 97.3 & 51.6 & 0.7 & 10.8 \\
\hline \multirow{6}{*}{$\begin{array}{l}\text { Service } \\
\text { utilized }\end{array}$} & Alert & 98.7 & 65.6 & 1.4 & 16.4 \\
\hline & Email & 97.9 & 61.0 & 1.3 & 14.9 \\
\hline & Customer service call & 97.5 & 52.1 & 0.8 & 10.2 \\
\hline & Web & 98.0 & 61.9 & 1.3 & 15.0 \\
\hline & Overdraft & 99.9 & 98.3 & 5.8 & 39.8 \\
\hline & Overdraft buffer & 99.8 & 69.8 & 1.4 & 15.0 \\
\hline
\end{tabular}


Table 4.7: Share of Four Types of Debit Transactions among Cardholders

\begin{tabular}{|c|c|c|c|c|c|c|c|c|c|}
\hline \multirow{3}{*}{\multicolumn{2}{|c|}{ Account characteristics }} & \multicolumn{8}{|c|}{ Share of transactions (\%) } \\
\hline & & \multicolumn{2}{|c|}{ Purchase } & \multicolumn{2}{|c|}{ ATM } & \multicolumn{2}{|c|}{ Bill payments } & \multicolumn{2}{|c|}{ Person-to-Person } \\
\hline & & Volume & Value & Volume & Value & Volume & Value & Volume & Value \\
\hline \multicolumn{2}{|l|}{ All } & 87.7 & 79.7 & 11.6 & 18.9 & 0.0 & 0.1 & 0.7 & 1.4 \\
\hline \multirow[t]{5}{*}{ Load type } & Never reload & 86.9 & 81.7 & 12.7 & 17.8 & 0.0 & 0.0 & 0.4 & 0.5 \\
\hline & Occasional reload & 89.2 & 82.3 & 10.1 & 16.3 & 0.0 & 0.0 & 0.7 & 1.3 \\
\hline & Periodic self-funded & 91.0 & 86.5 & 8.4 & 12.5 & 0.0 & 0.0 & 0.6 & 1.0 \\
\hline & Periodic government direct deposit & 73.1 & 54.6 & 25.7 & 41.8 & 0.1 & 0.2 & 1.2 & 3.4 \\
\hline & Periodic non-government direct deposit & 83.5 & 65.9 & 15.4 & 31.3 & 0.1 & 0.2 & 1.1 & 2.6 \\
\hline \multirow[t]{2}{*}{ Fee program type } & Per transaction & 88.1 & 81.8 & 11.3 & 17.1 & 0.0 & 0.0 & 0.6 & 1.1 \\
\hline & Monthly & 86.3 & 72.8 & 12.7 & 24.6 & 0.1 & 0.2 & 0.9 & 2.4 \\
\hline \multirow[t]{6}{*}{ Distributor type } & Check casher & 89.2 & 82.2 & 10.2 & 16.6 & 0.0 & 0.0 & 0.6 & 1.2 \\
\hline & Direct & 84.5 & 73.4 & 14.2 & 24.1 & 0.1 & 0.2 & 1.3 & 2.3 \\
\hline & Retail & 90.0 & 84.6 & 9.4 & 14.4 & 0.0 & 0.0 & 0.6 & 1.0 \\
\hline & Disbursement & 82.9 & 73.3 & 16.9 & 26.3 & 0.0 & 0.0 & 0.2 & 0.3 \\
\hline & Tax & 68.1 & 55.3 & 31.5 & 44.0 & 0.0 & 0.0 & 0.3 & 0.7 \\
\hline & Other & 86.8 & 77.7 & 12.4 & 20.7 & 0.0 & 0.1 & 0.8 & 1.6 \\
\hline \multirow[t]{6}{*}{ Service utilized } & Alert & 86.8 & 76.2 & 12.3 & 21.7 & 0.0 & 0.1 & 0.9 & 2.0 \\
\hline & Email & 86.6 & 76.9 & 12.4 & 21.0 & 0.0 & 0.1 & 1.0 & 2.0 \\
\hline & Customer service call & 87.5 & 79.2 & 11.8 & 19.3 & 0.0 & 0.1 & 0.7 & 1.4 \\
\hline & Web & 86.6 & 76.7 & 12.4 & 21.2 & 0.0 & 0.1 & 1.0 & 2.0 \\
\hline & Overdraft & 80.1 & 61.0 & 18.7 & 35.4 & 0.1 & 0.3 & 1.2 & 3.3 \\
\hline & Overdraft buffer & 87.3 & 76.4 & 11.9 & 21.7 & 0.7 & 1.4 & 0.8 & 1.8 \\
\hline
\end{tabular}


Table 4.8a: Results for Shares of Purchase and ATM Transactions: Coefficients for Account Characteristics

Share in Volume

\begin{tabular}{|c|c|c|c|c|c|c|c|}
\hline \multirow{2}{*}{$\begin{array}{l}\text { Debit type } \\
\text { Specification }\end{array}$} & & \multicolumn{3}{|c|}{ Purchases } & \multicolumn{3}{|c|}{ ATM } \\
\hline & & 1 & 1 & 2 & 1 & 1 & 2 \\
\hline Sample & & National & Texas & Texas & National & Texas & Texas \\
\hline \multirow{6}{*}{ Load type } & Never & $\begin{array}{c}-0.019^{* * *} \\
(0.001)\end{array}$ & $\begin{array}{c}-0.024^{* * *} \\
(0.003)\end{array}$ & $\begin{array}{c}-0.022^{* * *} \\
(0.002)\end{array}$ & $\begin{array}{l}0.024^{* * *} \\
(0.001)\end{array}$ & $\begin{array}{l}0.028^{* * *} \\
(0.003)\end{array}$ & $\begin{array}{l}0.027^{* * *} \\
(0.002)\end{array}$ \\
\hline & Occasionally & $\begin{array}{l}-0.015^{* * *} \\
(0.001)\end{array}$ & $\begin{array}{c}-0.016^{* * *} \\
(0.001)\end{array}$ & $\begin{array}{c}-0.015^{* * *} \\
(0.001)\end{array}$ & $\begin{array}{l}0.017^{* * *} \\
(0.001)\end{array}$ & $\begin{array}{l}0.017^{* * *} \\
(0.001)\end{array}$ & $\begin{array}{l}0.016^{* * *} \\
(0.001)\end{array}$ \\
\hline & Government direct deposit & $-0.194^{* * *}$ & $-0.173^{* * *}$ & $-0.170^{* * *}$ & $0.189^{* * *}$ & $0.168^{* * *}$ & $0.165^{* * *}$ \\
\hline & & $(0.002)$ & $(0.003)$ & $(0.003)$ & $(0.002)$ & $(0.003)$ & $(0.003)$ \\
\hline & Non-government direct deposit & $-0.087^{* * *}$ & $-0.085^{* * *}$ & $-0.084^{* * *}$ & $0.086^{* * *}$ & $0.084^{* * *}$ & $0.083^{* * *}$ \\
\hline & & $(0.001)$ & $(0.001)$ & $(0.001)$ & $(0.001)$ & $(0.001)$ & $(0.001)$ \\
\hline $\begin{array}{l}\text { Fee program } \\
\text { type }\end{array}$ & Per transaction & $\begin{array}{c}-0.026^{* * *} \\
(0.000)\end{array}$ & $\begin{array}{c}-0.023^{* * *} \\
(0.001)\end{array}$ & $\begin{array}{c}-0.021^{* * *} \\
(0.001)\end{array}$ & $\begin{array}{l}0.025^{* * *} \\
(0.000)\end{array}$ & $\begin{array}{l}0.022^{* * *} \\
(0.001)\end{array}$ & $\begin{array}{l}0.021^{* * *} \\
(0.001)\end{array}$ \\
\hline \multirow{9}{*}{$\begin{array}{l}\text { Distributor } \\
\text { type }\end{array}$} & Direct & $\begin{array}{l}-0.040^{* * *} \\
(0.001)\end{array}$ & $\begin{array}{l}-0.018^{* * *} \\
(0.001)\end{array}$ & $\begin{array}{c}-0.018^{* * *} \\
(0.001)\end{array}$ & $\begin{array}{l}0.034^{* * *} \\
(0.001)\end{array}$ & $\begin{array}{l}0.012^{* * *} \\
(0.001)\end{array}$ & $\begin{array}{l}0.011^{* * *} \\
(0.001)\end{array}$ \\
\hline & Retail & $0.007^{* * *}$ & $0.009^{* * *}$ & 0.002 & $-0.007^{* * *}$ & $-0.008^{* * *}$ & -0.001 \\
\hline & & $(0.001)$ & $(0.001)$ & $(0.001)$ & $(0.001)$ & $(0.001)$ & $(0.001)$ \\
\hline & Disbursement & $-0.061^{* * *}$ & $-0.097^{* * *}$ & $-0.102^{* * *}$ & $0.064^{* * *}$ & $0.100^{* * *}$ & $0.104^{* * *}$ \\
\hline & & $(0.002)$ & $(0.004)$ & $(0.004)$ & $(0.002)$ & $(0.004)$ & $(0.004)$ \\
\hline & Tax & $-0.218^{* * *}$ & $-0.196^{* * *}$ & $-0.197^{* * *}$ & $0.223^{* * *}$ & $0.201^{* * *}$ & $0.202^{* * *}$ \\
\hline & & $(0.003)$ & $(0.011)$ & $(0.011)$ & $(0.003)$ & $(0.011)$ & $(0.011)$ \\
\hline & Other & $-0.016^{* * *}$ & $0.005^{* *}$ & $0.005^{* *}$ & $0.014^{* * *}$ & $-0.008^{* * *}$ & $-0.007^{* * *}$ \\
\hline & & $(0.002)$ & $(0.002)$ & $(0.002)$ & $(0.002)$ & $(0.002)$ & $(0.002)$ \\
\hline \multirow{4}{*}{$\begin{array}{l}\text { Overdraft } \\
\text { status }\end{array}$} & Overdraft & $-0.012^{* * *}$ & $-0.021^{* * * *}$ & $-0.020^{* * *}$ & $0.013^{* * *}$ & $0.022^{* * *}$ & $0.022^{* * *}$ \\
\hline & & $(0.001)$ & $(0.001)$ & $(0.001)$ & $(0.001)$ & $(0.001)$ & $(0.001)$ \\
\hline & Overdraft buffer & $0.029^{* * *}$ & $0.014^{* * *}$ & $0.014^{* * *}$ & $-0.024^{* * *}$ & $-0.010^{* * *}$ & $-0.011^{* * *}$ \\
\hline & & $(0.001)$ & $(0.001)$ & $(0.001)$ & $(0.001)$ & $(0.001)$ & $(0.001)$ \\
\hline \multirow{8}{*}{ Service utilized } & Email & $0.002^{* * *}$ & $0.003^{* * *}$ & $0.002^{* * *}$ & $-0.006^{* * *}$ & $-0.008^{* * *}$ & $-0.007^{* * *}$ \\
\hline & & $(0.001)$ & $(0.001)$ & $(0.001)$ & $(0.001)$ & $(0.001)$ & $(0.001)$ \\
\hline & Customer service call & $-0.018^{* * *}$ & $-0.013^{* * *}$ & $-0.011^{* * *}$ & $0.017^{* * *}$ & $0.012^{* * *}$ & $0.010^{* * *}$ \\
\hline & & $(0.001)$ & $(0.003)$ & $(0.003)$ & $(0.001)$ & $(0.003)$ & $(0.003)$ \\
\hline & Web & $-0.011^{* * *}$ & $-0.009^{* * *}$ & $-0.010^{* * *}$ & $0.007^{* * *}$ & $0.004^{* * *}$ & $0.005^{* * *}$ \\
\hline & & $(0.001)$ & $(0.001)$ & $(0.001)$ & $(0.001)$ & $(0.001)$ & $(0.001)$ \\
\hline & Alerts & $0.004^{* * *}$ & $-0.002^{* * *}$ & $-0.001^{* *}$ & $-0.006^{* * *}$ & 0.001 & 0.000 \\
\hline & & $(0.000)$ & $(0.001)$ & $(0.001)$ & $(0.000)$ & $(0.001)$ & $(0.001)$ \\
\hline \multirow{5}{*}{ 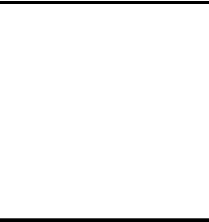 } & Constant & $0.948^{* * *}$ & $0.970^{* * *}$ & $0.934^{* * *}$ & $0.050^{* * *}$ & $0.029^{* * *}$ & $0.070^{* *}$ \\
\hline & & $(0.001)$ & $(0.003)$ & $(0.035)$ & $(0.001)$ & $(0.003)$ & $(0.034)$ \\
\hline & Controls? & no & no & yes & no & no & yes \\
\hline & Observations & $3,033,006$ & 630,858 & 630,858 & $3,033,006$ & 630,858 & 630,858 \\
\hline & Adjusted R-squared & 0.074 & 0.090 & 0.099 & 0.072 & 0.090 & 0.100 \\
\hline
\end{tabular}

Notes: Standard errors are shown in parentheses. All variables are dummy. The vector of controls includes zip-code level demographic characteristics.

$* * *, * *, *$ Significant at the $0.01,0.05$, and 0.10 level, respectively. 
Table 4.8a: Results for Shares of Purchase and ATM Transactions: Coefficients for Account Characteristics (cont.)

Share in Value

\begin{tabular}{|c|c|c|c|c|c|c|c|}
\hline \multirow{2}{*}{$\begin{array}{l}\text { Debit type } \\
\text { Specification }\end{array}$} & & \multicolumn{3}{|c|}{ Purchases } & \multicolumn{3}{|c|}{ ATM } \\
\hline & & 1 & 1 & 2 & 1 & 1 & 2 \\
\hline Sample & & National & Texas & Texas & National & Texas & Texas \\
\hline \multirow{4}{*}{ Load type } & Never & $\begin{array}{c}-0.022^{* * *} \\
(0.001)\end{array}$ & $\begin{array}{c}-0.030^{* * *} \\
(0.003)\end{array}$ & $\begin{array}{c}-0.027^{* * *} \\
(0.003)\end{array}$ & $\begin{array}{l}0.028^{* * *} \\
(0.001)\end{array}$ & $\begin{array}{l}0.036^{* * *} \\
(0.003)\end{array}$ & $\begin{array}{l}0.034^{* * *} \\
(0.003)\end{array}$ \\
\hline & Occasionally & $\begin{array}{c}-0.028^{* * *} \\
(0.001)\end{array}$ & $\begin{array}{c}-0.031^{* * *} \\
(0.001)\end{array}$ & $\begin{array}{c}-0.030^{* * *} \\
(0.001)\end{array}$ & $\begin{array}{l}0.029^{* * * *} \\
(0.001)\end{array}$ & $\begin{array}{l}0.032^{* * *} \\
(0.001)\end{array}$ & $\begin{array}{c}0.030^{* * *} \\
(0.001)\end{array}$ \\
\hline & Government direct deposit & $-0.312^{* * *}$ & $\begin{array}{c}-0.303^{* * *} \\
(0.004)\end{array}$ & $\begin{array}{c}-0.299^{* * *} \\
(0.003)\end{array}$ & $\begin{array}{l}0.294^{* * * *} \\
(0.002)\end{array}$ & $\begin{array}{l}0.284^{* * * *} \\
(0.003)\end{array}$ & $\begin{array}{l}0.279^{* * *} \\
(0.003)\end{array}$ \\
\hline & Non-government direct deposit & $\begin{array}{c}-0.195^{* * * *} \\
(0.001)\end{array}$ & $\begin{array}{c}-0.196 \\
(0.002)\end{array}$ & $\begin{array}{c}-0.195^{* * * *} \\
(0.002)\end{array}$ & $\begin{array}{l}0.186^{* * * *} \\
(0.001)\end{array}$ & $\begin{array}{l}0.187^{* * * *} \\
(0.002)\end{array}$ & $\begin{array}{l}0.186^{* * * *} \\
(0.002)\end{array}$ \\
\hline $\begin{array}{l}\text { Fee program } \\
\text { type }\end{array}$ & Per transaction & $\begin{array}{c}-0.014^{* * * *} \\
(0.001)\end{array}$ & $\begin{array}{c}-0.013^{* * * *} \\
(0.001)\end{array}$ & $\begin{array}{c}-0.012^{* * * *} \\
(0.001)\end{array}$ & $\begin{array}{l}0.017^{* * * *} \\
(0.001)\end{array}$ & $\begin{array}{l}0.017^{* * * *} \\
(0.001)\end{array}$ & $\begin{array}{l}0.015^{* * * *} \\
(0.001)\end{array}$ \\
\hline \multirow{5}{*}{$\begin{array}{l}\text { Distributor } \\
\text { type }\end{array}$} & Direct & $\begin{array}{c}-0.059^{* * * *} \\
(0.001)\end{array}$ & $\begin{array}{c}-0.033^{* * * *} \\
(0.001)\end{array}$ & $\begin{array}{c}-0.033^{* * * *} \\
(0.001)\end{array}$ & $\begin{array}{l}0.051^{* * *} \\
(0.001)\end{array}$ & $\begin{array}{l}0.024^{* * * *} \\
(0.001)\end{array}$ & $\begin{array}{l}0.024^{* * * *} \\
(0.001)\end{array}$ \\
\hline & Retail & $\begin{array}{l}0.007^{* * *} \\
(0.001)\end{array}$ & $\begin{array}{l}0.016^{* * *} \\
(0.002)\end{array}$ & $\begin{array}{l}0.007^{* * * *} \\
(0.002)\end{array}$ & $\begin{array}{c}-0.006^{* * * *} \\
(0.001)\end{array}$ & $\begin{array}{c}-0.013^{* * * *} \\
(0.002)\end{array}$ & $\begin{array}{l}-0.005^{* *} \\
(0.002)\end{array}$ \\
\hline & Disbursement & $\begin{array}{c}-0.110^{* * * *} \\
(0.002)\end{array}$ & $\begin{array}{c}-0.163^{* * * *} \\
(0.006)\end{array}$ & $\begin{array}{c}-0.170^{* * * *} \\
(0.006)\end{array}$ & $\begin{array}{l}0.115^{* * *} \\
(0.002)\end{array}$ & $\begin{array}{l}0.167^{* * * *} \\
(0.006)\end{array}$ & $\begin{array}{l}0.173^{* * * *} \\
(0.006)\end{array}$ \\
\hline & Tax & $\begin{array}{c}-0.299^{* * *} \\
(0.003)\end{array}$ & $\begin{array}{c}-0.273^{* * *} \\
(0.013)\end{array}$ & $\begin{array}{c}-0.275^{* * *} \\
(0.012)\end{array}$ & $\begin{array}{l}0.305^{* * * *} \\
(0.003)\end{array}$ & $\begin{array}{l}0.281^{* * *} \\
(0.013)\end{array}$ & $\begin{array}{c}0.282^{* * *} \\
(0.013)\end{array}$ \\
\hline & Other & $\begin{array}{c}-0.017^{* * * *} \\
(0.002)\end{array}$ & $\begin{array}{l}0.015^{* * * *} \\
(0.003)\end{array}$ & $\begin{array}{l}0.014^{* * * *} \\
(0.003)\end{array}$ & $\begin{array}{l}0.016^{* * * *} \\
(0.002)\end{array}$ & $\begin{array}{c}-0.017^{* * * *} \\
(0.003)\end{array}$ & $\begin{array}{c}-0.016^{* * * *} \\
(0.003) \\
\end{array}$ \\
\hline \multirow{2}{*}{$\begin{array}{l}\text { Overdraft } \\
\text { status }\end{array}$} & Overdraft & $\begin{array}{c}-0.025^{* * *} \\
(0.001)\end{array}$ & $\begin{array}{c}-0.026^{* * *} \\
(0.002)\end{array}$ & $\begin{array}{c}-0.025^{* * *} \\
(0.002)\end{array}$ & $\begin{array}{l}0.023^{* * *} \\
(0.001)\end{array}$ & $\begin{array}{l}0.024^{* * * *} \\
(0.002)\end{array}$ & $\begin{array}{l}0.023^{* * *} \\
(0.002)\end{array}$ \\
\hline & Overdraft buffer & $\begin{array}{l}0.016^{* * * *} \\
(0.001)\end{array}$ & $\begin{array}{c}0.001 \\
(0.001)\end{array}$ & $\begin{array}{c}0.001 \\
(0.001)\end{array}$ & $\begin{array}{c}-0.011^{* * * *} \\
(0.001)\end{array}$ & $\begin{array}{l}0.003^{* * * *} \\
(0.001)\end{array}$ & $\begin{array}{l}0.002^{* *} \\
(0.001)\end{array}$ \\
\hline \multirow{8}{*}{ Service utilized } & Email & $\begin{array}{l}0.004^{* * *} \\
(0.001)\end{array}$ & $\begin{array}{l}0.006^{* * *} \\
(0.001)\end{array}$ & $\begin{array}{l}0.004^{* * *} \\
(0.001)\end{array}$ & $\begin{array}{c}-0.011^{* * *} \\
(0.001)\end{array}$ & $\begin{array}{c}-0.015^{* * *} \\
(0.001)\end{array}$ & $\begin{array}{c}-0.012^{* * * *} \\
(0.001)\end{array}$ \\
\hline & Customer service call & $\begin{array}{c}-0.039^{* * *} \\
(0.001)\end{array}$ & $\begin{array}{c}-0.034^{* * *} \\
(0.003)\end{array}$ & $\begin{array}{c}-0.032^{* * *} \\
(0.003)\end{array}$ & $\begin{array}{l}0.036^{* * *} \\
(0.001)\end{array}$ & $\begin{array}{c}0.031^{* * *} \\
(0.003)\end{array}$ & $\begin{array}{c}0.028^{* * *} \\
(0.003)\end{array}$ \\
\hline & Web & $\begin{array}{c}-0.016^{* * *} \\
(0.001)\end{array}$ & $\begin{array}{c}-0.015^{* * *} \\
(0.001)\end{array}$ & $\begin{array}{c}-0.016^{* * * *} \\
(0.001)\end{array}$ & $\begin{array}{l}0.010^{* * * *} \\
(0.001)\end{array}$ & $\begin{array}{l}0.008^{* * * *} \\
(0.001)\end{array}$ & $\begin{array}{c}0.009^{* * *} \\
(0.001)\end{array}$ \\
\hline & Alerts & $\begin{array}{c}-0.004^{* * *} \\
(0.001)\end{array}$ & $\begin{array}{c}-0.009^{* * *} \\
(0.001)\end{array}$ & $\begin{array}{c}-0.008^{* * *} \\
(0.001)\end{array}$ & $\begin{array}{c}0.000 \\
(0.001)\end{array}$ & $\begin{array}{l}0.005^{* * * *} \\
(0.001)\end{array}$ & $\begin{array}{l}0.004^{* * * *} \\
(0.001)\end{array}$ \\
\hline & Constant & $\begin{array}{l}0.927^{* * * *} \\
(0.001)\end{array}$ & $\begin{array}{l}0.952^{* * * *} \\
(0.003)\end{array}$ & $\begin{array}{l}0.882^{* * * *} \\
(0.049)\end{array}$ & $\begin{array}{l}0.069^{* * * *} \\
(0.001)\end{array}$ & $\begin{array}{l}0.045^{* * * *} \\
(0.003)\end{array}$ & $\begin{array}{l}0.117^{* * * *} \\
(0.047)\end{array}$ \\
\hline & Controls? & no & no & yes & no & no & yes \\
\hline & Observations & $3,032,956$ & 630,849 & 630,849 & $3,032,956$ & 630,849 & 630,849 \\
\hline & Adjusted R-squared & 0.130 & 0.162 & 0.169 & 0.119 & 0.148 & 0.155 \\
\hline
\end{tabular}

Notes: Standard errors are shown in parentheses. All variables are dummy. The vector of controls includes zip-code level demographic characteristics.

$* * *, * *, *$ Significant at the $0.01,0.05$, and 0.10 level, respectively. 
Table 4.8b: Results for Shares of Purchase and ATM Transactions: Coefficients for Zipcode Level Demographic Characteristics

\section{Share in Volume}

\begin{tabular}{|c|c|c|c|}
\hline \multicolumn{2}{|l|}{ Debit type } & Purchase & ATM \\
\hline & Female & $\begin{array}{l}-0.022 \\
(0.027) \\
\end{array}$ & $\begin{array}{c}0.025 \\
(0.026) \\
\end{array}$ \\
\hline \multirow{6}{*}{ Race } & Black & $\begin{array}{c}-0.066^{* * *} \\
(0.006)\end{array}$ & $\begin{array}{l}0.063^{* * *} \\
(0.006)\end{array}$ \\
\hline & American Indian & $\begin{array}{l}-0.096 \\
(0.110)\end{array}$ & $\begin{array}{c}0.102 \\
(0.107)\end{array}$ \\
\hline & Asian & $\begin{array}{l}0.026^{* *} \\
(0.012)\end{array}$ & $\begin{array}{c}-0.032^{* * *} \\
(0.011)\end{array}$ \\
\hline & Hawaiian & $\begin{array}{l}-0.040 \\
(0.169)\end{array}$ & $\begin{array}{c}0.066 \\
(0.157)\end{array}$ \\
\hline & Other & $\begin{array}{c}0.000 \\
(0.007)\end{array}$ & $\begin{array}{c}0.002 \\
(0.007)\end{array}$ \\
\hline & Multiple race & $\begin{array}{l}-0.075^{*} \\
(0.043) \\
\end{array}$ & $\begin{array}{c}0.078^{*} \\
(0.042) \\
\end{array}$ \\
\hline & Hispanic & $\begin{array}{c}0.005 \\
(0.004)\end{array}$ & $\begin{array}{l}-0.006 \\
(0.004)\end{array}$ \\
\hline \multirow{6}{*}{ Age } & 15 and under & $\begin{array}{l}0.139^{* * *} \\
(0.035)\end{array}$ & $\begin{array}{c}-0.138^{* * *} \\
(0.035)\end{array}$ \\
\hline & 15 to 24 & $\begin{array}{l}0.052^{* *} \\
(0.026)\end{array}$ & $\begin{array}{l}-0.048^{*} \\
(0.026)\end{array}$ \\
\hline & 35 to 44 & $\begin{array}{c}0.058 \\
(0.050)\end{array}$ & $\begin{array}{l}-0.072 \\
(0.049)\end{array}$ \\
\hline & 45 to 54 & $\begin{array}{c}0.019 \\
(0.037)\end{array}$ & $\begin{array}{l}-0.023 \\
(0.036)\end{array}$ \\
\hline & 55 to 64 & $\begin{array}{l}0.087^{* *} \\
(0.039)\end{array}$ & $\begin{array}{l}-0.089^{* *} \\
(0.039)\end{array}$ \\
\hline & 65 and over & $\begin{array}{c}0.055 \\
(0.037)\end{array}$ & $\begin{array}{l}-0.060^{*} \\
(0.036)\end{array}$ \\
\hline \multirow{4}{*}{$\begin{array}{c}\text { Marital } \\
\text { status }\end{array}$} & Married & $\begin{array}{l}-0.013 \\
(0.019)\end{array}$ & $\begin{array}{c}0.014 \\
(0.019)\end{array}$ \\
\hline & Widowed & $\begin{array}{l}-0.066 \\
(0.049)\end{array}$ & $\begin{array}{c}0.085^{*} \\
(0.048)\end{array}$ \\
\hline & Divorced & $\begin{array}{c}0.011 \\
(0.039)\end{array}$ & $\begin{array}{l}-0.010 \\
(0.038)\end{array}$ \\
\hline & Sep arated & $\begin{array}{l}-0.030 \\
(0.067)\end{array}$ & $\begin{array}{c}0.021 \\
(0.064)\end{array}$ \\
\hline
\end{tabular}

\begin{tabular}{|c|c|c|c|}
\hline \multicolumn{2}{|l|}{ Debit type } & Purchase & ATM \\
\hline \multirow{12}{*}{ Education } & \multirow[t]{2}{*}{ Less than 9th grade } & $-0.040^{* *}$ & $0.040^{* *}$ \\
\hline & & (0.019) & $(0.018)$ \\
\hline & \multirow[t]{2}{*}{ Less than 12th grade } & $-0.105^{* * *}$ & $0.100^{* * *}$ \\
\hline & & $(0.030)$ & $(0.029)$ \\
\hline & \multirow{2}{*}{ Some college } & $0.052^{* *}$ & $-0.051^{* *}$ \\
\hline & & $(0.023)$ & $(0.022)$ \\
\hline & \multirow[t]{2}{*}{ Associate's degree } & -0.032 & 0.025 \\
\hline & & $(0.037)$ & $(0.037)$ \\
\hline & \multirow[t]{2}{*}{ Bachelor's degree } & $0.058^{* * *}$ & $-0.066^{* * *}$ \\
\hline & & $(0.021)$ & $(0.021)$ \\
\hline & \multirow[t]{2}{*}{ Graduate degree } & $-0.099^{* * *}$ & $0.101^{* * *}$ \\
\hline & & $(0.028)$ & $(0.028)$ \\
\hline \multirow{18}{*}{ Income } & \multirow[t]{2}{*}{ Less than $\$ 10,000$} & 0.017 & -0.017 \\
\hline & & $(0.027)$ & $(0.026)$ \\
\hline & \multirow[t]{2}{*}{$\$ 10,000-\$ 15,000$} & -0.041 & 0.044 \\
\hline & & $(0.038)$ & $(0.037)$ \\
\hline & \multirow{2}{*}{$\$ 15,000-\$ 25,000$} & 0.05 & $-0.056^{*}$ \\
\hline & & $(0.033)$ & $(0.032)$ \\
\hline & \multirow[t]{2}{*}{$\$ 25,000-\$ 35,000$} & -0.002 & 0.000 \\
\hline & & $(0.033)$ & -0.032 \\
\hline & \multirow[t]{2}{*}{$\$ 50,000-\$ 75,000$} & 0.031 & -0.033 \\
\hline & & $(0.029)$ & $(0.032)$ \\
\hline & \multirow[t]{2}{*}{$\$ 75,000-\$ 100,000$} & 0.011 & -0.015 \\
\hline & & $(0.030)$ & $(0.029)$ \\
\hline & \multirow[t]{2}{*}{$\$ 100,000-\$ 150,000$} & -0.018 & 0.013 \\
\hline & & $(0.027)$ & $(0.026)$ \\
\hline & \multirow[t]{2}{*}{$\$ 150,000-\$ 200,000$} & -0.020 & 0.027 \\
\hline & & $(0.043)$ & $(0.042)$ \\
\hline & \multirow[t]{2}{*}{ More than $\$ 200,000$} & -0.021 & 0.019 \\
\hline & & $(0.034)$ & $(0.034)$ \\
\hline \multirow{6}{*}{$\begin{array}{c}\text { Crime } \\
\text { incidents } \\
\text { per } 10,000 \\
\text { residents } \\
\end{array}$} & Violent & $-0.017^{* * *}$ & $0.019^{* * *}$ \\
\hline & \multirow{3}{*}{ Property } & $(0.004)$ & $(0.034)$ \\
\hline & & $0.002^{* * *}$ & $-0.002^{* * *}$ \\
\hline & & $(0.001)$ & $(0.001)$ \\
\hline & Observations & 630,858 & 630,858 \\
\hline & Adjusted R-squared & 0.099 & 0.100 \\
\hline
\end{tabular}

Notes: Standard errors are shown in parentheses. Crime incidents per 1,000 residents is continuous, and the other variables are dummy. Default race is White. Default age bracket is $25-34$. Default education is High School. Default income bracket is $\$ 35,000-\$ 50,000$.

$* * *, * *, *$ Significant at the $0.01,0.05$, and 0.10 level, respectively.

Sources: The authors' calculations using 2011 American Community Survey (sex, race, ethnicity, age, education, income, and marital status), 2010 FBI Uniform Crime Report (violent and property crime), and Net Spend. 
Table 4.8b: Results for Shares of Purchase and ATM Transactions: Coefficients for Zipcode Level Demographic Characteristics (cont.)

\section{Share in Value}

\begin{tabular}{|c|c|c|c|}
\hline \multicolumn{2}{|l|}{ Debit type } & Purchase & ATM \\
\hline & Female & $\begin{array}{l}-0.015 \\
(0.039) \\
\end{array}$ & $\begin{array}{c}0.022 \\
(0.038) \\
\end{array}$ \\
\hline \multirow{6}{*}{ Race } & Black & $\begin{array}{c}-0.083^{* * *} \\
(0.008)\end{array}$ & $\begin{array}{l}0.076^{* * *} \\
(0.008)\end{array}$ \\
\hline & American Indian & $\begin{array}{c}-0.142 \\
(0.161)\end{array}$ & $\begin{array}{c}0.156 \\
(0.158)\end{array}$ \\
\hline & Asian & $\begin{array}{l}0.039^{* *} \\
(0.018)\end{array}$ & $\begin{array}{c}-0.055^{* * *} \\
(0.016)\end{array}$ \\
\hline & Hawaiian & $\begin{array}{c}0.151 \\
(0.257)\end{array}$ & $\begin{array}{l}-0.130 \\
(0.223)\end{array}$ \\
\hline & Other & $\begin{array}{c}0.000 \\
(0.011)\end{array}$ & $\begin{array}{c}0.004 \\
(0.011)\end{array}$ \\
\hline & Multiple race & $\begin{array}{l}-0.144^{* *} \\
(0.068)\end{array}$ & $\begin{array}{l}0.152^{* *} \\
(0.065)\end{array}$ \\
\hline & Hispanic & $\begin{array}{c}0.004 \\
(0.007)\end{array}$ & $\begin{array}{l}-0.006 \\
(0.006)\end{array}$ \\
\hline \multirow{6}{*}{ Age } & 15 and under & $\begin{array}{l}0.189^{* * *} \\
(0.050)\end{array}$ & $\begin{array}{c}-0.184^{* * *} \\
(0.049)\end{array}$ \\
\hline & 15 to 24 & $\begin{array}{l}0.088^{* *} \\
(0.036)\end{array}$ & $\begin{array}{l}-0.078^{* *} \\
(0.035)\end{array}$ \\
\hline & 35 to 44 & $\begin{array}{l}0.138^{*} \\
(0.075)\end{array}$ & $\begin{array}{c}-0.150^{* *} \\
(0.072)\end{array}$ \\
\hline & 45 to 54 & $\begin{array}{c}0.023 \\
(0.052)\end{array}$ & $\begin{array}{l}-0.023 \\
(0.050)\end{array}$ \\
\hline & 55 to 64 & $\begin{array}{l}0.150^{* * *} \\
(0.055)\end{array}$ & $\begin{array}{c}-0.152^{* * *} \\
(0.054)\end{array}$ \\
\hline & 65 and over & $\begin{array}{c}0.073 \\
(0.056)\end{array}$ & $\begin{array}{c}-0.072 \\
(0.054)\end{array}$ \\
\hline \multirow{4}{*}{$\begin{array}{l}\text { Marital } \\
\text { status }\end{array}$} & Married & $\begin{array}{l}-0.012 \\
(0.027)\end{array}$ & $\begin{array}{c}0.015 \\
(0.026)\end{array}$ \\
\hline & Widowed & $\begin{array}{l}-0.051 \\
(0.076)\end{array}$ & $\begin{array}{c}0.074 \\
(0.074)\end{array}$ \\
\hline & Divorced & $\begin{array}{c}0.000 \\
(0.054)\end{array}$ & $\begin{array}{c}-0.002 \\
(0.052)\end{array}$ \\
\hline & Sep arated & $\begin{array}{l}-0.011 \\
-0.101\end{array}$ & $\begin{array}{c}0.015 \\
(0.096)\end{array}$ \\
\hline
\end{tabular}

\begin{tabular}{|c|c|c|c|}
\hline Debit type & & Purchase & ATM \\
\hline \multirow{12}{*}{ Education } & \multirow[t]{2}{*}{ Less than 9th grade } & $-0.051^{*}$ & $0.050^{*}$ \\
\hline & & $(0.028)$ & $(0.027)$ \\
\hline & \multirow[t]{2}{*}{ Less than 12 th grade } & $-0.146^{* * *}$ & $0.137^{* * *}$ \\
\hline & & $(0.043)$ & $(0.042)$ \\
\hline & \multirow[t]{2}{*}{ Some college } & $0.056^{*}$ & $-0.056^{*}$ \\
\hline & & $(0.032)$ & $(0.031)$ \\
\hline & \multirow[t]{2}{*}{ Associate's degree } & -0.048 & 0.038 \\
\hline & & $(0.057)$ & $(0.054)$ \\
\hline & \multirow[t]{2}{*}{ Bachelor's degree } & $0.077^{*}$ & $-0.092^{* * *}$ \\
\hline & & $(0.030)$ & $(0.029)$ \\
\hline & \multirow[t]{2}{*}{ Graduate degree } & $-0.115^{* * *}$ & $0.125^{* * *}$ \\
\hline & & $(0.037)$ & $(0.036)$ \\
\hline \multirow{18}{*}{ Income } & \multirow[t]{2}{*}{ Less than $\$ 10,000$} & 0.018 & -0.015 \\
\hline & & $(0.035)$ & $(0.035)$ \\
\hline & \multirow[t]{2}{*}{$\$ 10,000-\$ 15,000$} & -0.048 & 0.054 \\
\hline & & $(0.057)$ & $(0.054)$ \\
\hline & \multirow[t]{2}{*}{$\$ 15,000-\$ 25,000$} & 0.075 & $-0.082^{*}$ \\
\hline & & $(0.048)$ & $(0.047)$ \\
\hline & \multirow[t]{2}{*}{$\$ 25,000-\$ 35,000$} & -0.012 & 0.009 \\
\hline & & $(0.049)$ & $(0.047)$ \\
\hline & \multirow[t]{2}{*}{$\$ 50,000-\$ 75,000$} & 0.045 & -0.050 \\
\hline & & $(0.042)$ & $(0.041)$ \\
\hline & \multirow[t]{2}{*}{$\$ 75,000-\$ 100,000$} & 0.024 & -0.024 \\
\hline & & $(0.042)$ & $(0.041)$ \\
\hline & \multirow[t]{2}{*}{$\$ 100,000-\$ 150,000$} & -0.018 & 0.003 \\
\hline & & (0.039) & $(0.038)$ \\
\hline & \multirow[t]{2}{*}{$\$ 150,000-\$ 200,000$} & -0.032 & 0.038 \\
\hline & & $(0.063)$ & $(0.061)$ \\
\hline & \multirow[t]{2}{*}{ More than $\$ 200,000$} & -0.025 & 0.024 \\
\hline & & $(0.051)$ & $(0.050)$ \\
\hline \multirow{6}{*}{$\begin{array}{c}\text { Crime } \\
\text { incidents } \\
\text { per } 10,000 \\
\text { residents }\end{array}$} & Violent & $-0.015^{* *}$ & $0.019^{* *}$ \\
\hline & \multirow{3}{*}{ Property } & $(0.006)$ & $(0.006)$ \\
\hline & & 0.000 & -0.001 \\
\hline & & $(0.001)$ & $(0.001)$ \\
\hline & Observations & 630,849 & 630,849 \\
\hline & Adjusted R-squared & 0.169 & 0.155 \\
\hline
\end{tabular}

Notes: Standard errors are shown in parentheses. Crime incidents per 1,000 residents is continuous, and the other variables are dummy. Default race is White. Default age bracket is $25-34$. Default education is High School. Default income bracket is $\$ 35,000-\$ 50,000$.

$* * *, * *, *$ Significant at the $0.01,0.05$, and 0.10 level, respectively.

Sources: The authors' calculations using 2011 American Community Survey (sex, race, ethnicity, age, education, income, and marital status), 2010 FBI Uniform Crime Report (violent and property crime), and Net Spend. 
Table 4.9: Purchase Activities per Month

\begin{tabular}{|c|c|c|c|c|c|c|c|c|c|}
\hline \multirow{4}{*}{\multicolumn{2}{|c|}{ Account characteristics }} & \multirow{3}{*}{\multicolumn{2}{|c|}{$\begin{array}{l}\text { Purchase transactions } \\
\text { per month }\end{array}$}} & \multicolumn{6}{|c|}{ Share (\%) } \\
\hline & & & & \multirow{2}{*}{\multicolumn{2}{|c|}{ PIN }} & \multicolumn{4}{|c|}{ Signature } \\
\hline & & & & & & \multicolumn{2}{|c|}{ Card-present } & \multicolumn{2}{|c|}{ Card-not-present } \\
\hline & & Volume & Value (\$) & Volume & Value & Volume & Value & Volume & Value \\
\hline \multicolumn{2}{|l|}{ All } & 7.0 & 303 & 29.0 & 28.7 & 27.7 & 22.0 & 43.3 & 49.3 \\
\hline \multirow[t]{5}{*}{ Load type } & Never reload & 2.9 & 167 & 30.5 & 31.1 & 35.3 & 31.4 & 34.2 & 37.5 \\
\hline & Occasional reload & 2.0 & 94 & 24.0 & 22.4 & 21.7 & 16.6 & 54.3 & 61.0 \\
\hline & Periodic self-funded & 5.7 & 266 & 25.9 & 24.1 & 28.4 & 22.6 & 45.7 & 53.3 \\
\hline & Periodic government direct deposit & 9.9 & 442 & 42.1 & 45.2 & 19.6 & 14.6 & 38.3 & 40.2 \\
\hline & Periodic non-government direct deposit & 18.1 & 660 & 35.3 & 37.8 & 26.1 & 18.5 & 38.6 & 43.7 \\
\hline \multirow[t]{2}{*}{ Fee program type } & Per transaction & 4.5 & 217 & 27.2 & 26.3 & 28.8 & 23.4 & 44.0 & 50.3 \\
\hline & Monthly & 15.4 & 584 & 34.9 & 36.4 & 24.1 & 17.7 & 41.0 & 45.9 \\
\hline \multirow[t]{6}{*}{ Distributor type } & Check casher & 7.1 & 288 & 29.2 & 28.5 & 26.3 & 20.6 & 44.5 & 50.8 \\
\hline & Direct & 7.6 & 331 & 29.3 & 30.1 & 31.4 & 25.8 & 39.2 & 44.1 \\
\hline & Retail & 6.5 & 291 & 22.2 & 21.3 & 25.7 & 19.6 & 52.1 & 59.1 \\
\hline & Disbursement & 5.4 & 266 & 35.3 & 35.3 & 28.1 & 23.4 & 36.6 & 41.4 \\
\hline & Tax & 10.8 & 1,098 & 43.3 & 45.1 & 40.5 & 36.9 & 16.3 & 18.0 \\
\hline & Other & 6.8 & 290 & 29.9 & 28.9 & 31.5 & 25.2 & 38.6 & 45.9 \\
\hline \multirow[t]{6}{*}{ Service utilized } & Alert & 10.0 & 407 & 30.5 & 30.7 & 25.4 & 19.1 & 44.1 & 50.2 \\
\hline & Email & 8.9 & 384 & 28.8 & 29.0 & 25.7 & 19.8 & 45.5 & 51.2 \\
\hline & Customer service call & 7.3 & 311 & 29.2 & 28.9 & 27.2 & 21.5 & 43.5 & 49.6 \\
\hline & Web & 9.1 & 389 & 29.1 & 29.3 & 25.5 & 19.5 & 45.4 & 51.2 \\
\hline & Overdraft & 19.8 & 793 & 36.9 & 40.3 & 23.1 & 15.9 & 40.0 & 43.8 \\
\hline & Overdraft buffer & 9.7 & 390 & 29.0 & 28.7 & 23.1 & 16.9 & 47.9 & 54.3 \\
\hline
\end{tabular}


Table 4.10a: Results for Shares of PIN and Signature Card-Not-Present Transactions: Coefficients for Account Characteristics

\begin{tabular}{|c|c|c|c|c|c|c|c|}
\hline \multirow{3}{*}{\multicolumn{2}{|c|}{$\begin{array}{l}\text { Debit type } \\
\text { Specification } \\
\end{array}$}} & \multicolumn{6}{|c|}{ Share in Volume } \\
\hline & & \multicolumn{3}{|c|}{ PIN } & \multicolumn{3}{|c|}{ Signature Card-not-present } \\
\hline & & (1) & (1) & (2) & (1) & (2) & $(2)$ \\
\hline Sample & & National & Texas & Texas & National & Texas & Texas \\
\hline \multirow{4}{*}{ Load type } & Never & $\begin{array}{l}0.039^{* * *} \\
(0.001)\end{array}$ & $\begin{array}{l}0.031^{* * *} \\
(0.002)\end{array}$ & $\begin{array}{l}0.030^{* * *} \\
(0.002)\end{array}$ & $\begin{array}{c}-0.078^{* * *} \\
(0.002)\end{array}$ & $\begin{array}{c}-0.072^{* * *} \\
(0.003)\end{array}$ & $\begin{array}{c}-0.074^{* * * *} \\
(0.003)\end{array}$ \\
\hline & Occasionally & $\begin{array}{c}-0.016^{* * *} \\
(0.001)\end{array}$ & $\begin{array}{c}-0.017^{* * * *} \\
(0.001)\end{array}$ & $\begin{array}{c}-0.018^{* * *} \\
(0.001)\end{array}$ & $\begin{array}{l}0.078^{* * *} \\
(0.001)\end{array}$ & $\begin{array}{l}0.079^{* * *} \\
(0.001)\end{array}$ & $\begin{array}{l}0.079^{* * * *} \\
(0.002)\end{array}$ \\
\hline & Government direct deposit & $\begin{array}{l}0.106^{* * *} \\
(0.001)\end{array}$ & $\begin{array}{l}0.102^{* * * *} \\
(0.002)\end{array}$ & $\begin{array}{c}0.101^{* * *} \\
(0.002)\end{array}$ & $\begin{array}{c}-0.051^{* * *} \\
(0.001)\end{array}$ & $\begin{array}{c}-0.046^{* * * *} \\
(0.002)\end{array}$ & $\begin{array}{c}-0.045^{* * *} \\
(0.002)\end{array}$ \\
\hline & Non-government direct deposit & $\begin{array}{c}0.059^{* * *} \\
(0.001) \\
\end{array}$ & $\begin{array}{l}0.079^{* * *} \\
(0.001) \\
\end{array}$ & - $\begin{array}{c}0.080^{* * *} \\
(0.001)\end{array}$ & $\begin{array}{c}-0.072^{* * *} \\
(0.001) \\
\end{array}$ & $\begin{array}{c}-0.085^{* * * *} \\
(0.002) \\
\end{array}$ & $\begin{array}{c}-0.085^{* * *} \\
(0.002) \\
\end{array}$ \\
\hline $\begin{array}{l}\text { Fee program } \\
\text { type }\end{array}$ & Per transaction & $\begin{array}{c}-0.053^{* * *} \\
(0.001) \\
\end{array}$ & $\begin{array}{c}-0.066^{* * *} \\
(0.001) \\
\end{array}$ & $\begin{array}{c}-0.067^{* * *} \\
(0.001) \\
\end{array}$ & $\begin{array}{l}0.036^{* * *} \\
(0.001)\end{array}$ & $\begin{array}{l}0.055^{* * *} \\
(0.001)\end{array}$ & $\begin{array}{l}0.055^{* * *} \\
(0.001) \\
\end{array}$ \\
\hline \multirow{5}{*}{$\begin{array}{l}\text { Distributor } \\
\text { type }\end{array}$} & Direct & $\begin{array}{c}-0.010^{* * *} \\
(0.001)\end{array}$ & $\begin{array}{c}-0.009^{* * *} \\
(0.001)\end{array}$ & $\begin{array}{c}-0.010^{* * *} \\
(0.001)\end{array}$ & $\begin{array}{c}-0.079^{* * *} \\
(0.001)\end{array}$ & $\begin{array}{l}-0.076^{* * * *} \\
(0.002)\end{array}$ & $\begin{array}{c}-0.075^{* * *} \\
(0.002)\end{array}$ \\
\hline & Retail & $\begin{array}{c}-0.060^{* * *} \\
(0.001)\end{array}$ & $\begin{array}{c}-0.041^{* * *} \\
(0.002)\end{array}$ & $\begin{array}{c}-0.037^{* * *} \\
(0.002)\end{array}$ & $\begin{array}{l}0.089^{* * * *} \\
(0.002)\end{array}$ & $\begin{array}{l}0.121^{* * *} \\
(0.003)\end{array}$ & $\begin{array}{c}0.125^{* * *} \\
(0.003)\end{array}$ \\
\hline & Disbursement & $\begin{array}{l}0.040^{* * *} \\
(0.003)\end{array}$ & $\begin{array}{l}0.032^{* * *} \\
(0.004)\end{array}$ & $\begin{array}{l}0.034^{* * *} \\
(0.004)\end{array}$ & $\begin{array}{c}-0.007^{* * *} \\
(0.003)\end{array}$ & $\begin{array}{l}-0.003 \\
(0.005)\end{array}$ & $\begin{array}{c}0.001 \\
(0.005)\end{array}$ \\
\hline & Tax & $\begin{array}{l}0.105^{* * *} \\
(0.003)\end{array}$ & $\begin{array}{l}0.134^{* * *} \\
(0.010)\end{array}$ & $\begin{array}{l}0.131^{* * *} \\
(0.010)\end{array}$ & $\begin{array}{c}-0.202^{* * *} \\
(0.003)\end{array}$ & $\begin{array}{c}-0.193^{* * * *} \\
(0.008)\end{array}$ & $\begin{array}{c}-0.192^{* * *} \\
(0.008)\end{array}$ \\
\hline & Other & $\begin{array}{c}-0.016^{* * *} \\
(0.002) \\
\end{array}$ & $\begin{array}{l}-0.011^{* *} \\
(0.005) \\
\end{array}$ & $\begin{array}{l}-0.009^{* *} \\
(0.005) \\
\end{array}$ & $\begin{array}{c}-0.052^{* * *} \\
(0.003) \\
\end{array}$ & $\begin{array}{c}-0.004 \\
(0.005) \\
\end{array}$ & $\begin{array}{l}-0.006 \\
(0.005) \\
\end{array}$ \\
\hline \multirow{2}{*}{$\begin{array}{l}\text { Overdraft } \\
\text { status }\end{array}$} & Overdraft & $\begin{array}{c}-0.019^{* * *} \\
(0.001)\end{array}$ & $\begin{array}{c}-0.024^{* * *} \\
(0.001)\end{array}$ & $\begin{array}{c}-0.024^{* * *} \\
(0.001)\end{array}$ & $\begin{array}{l}0.029^{* * *} \\
(0.001)\end{array}$ & $\begin{array}{l}0.049^{* * *} \\
(0.002)\end{array}$ & $\begin{array}{l}0.049^{* * *} \\
(0.002)\end{array}$ \\
\hline & Overdraft buffer & $\begin{array}{c}-0.031^{* * *} \\
(0.001) \\
\end{array}$ & $\begin{array}{c}-0.035^{* * *} \\
(0.001) \\
\end{array}$ & $\begin{array}{c}-0.036^{* * *} \\
(0.001) \\
\end{array}$ & $\begin{array}{l}0.116^{* * *} \\
(0.001)\end{array}$ & $\begin{array}{l}0.125^{* * *} \\
(0.002)\end{array}$ & $\begin{array}{l}0.126^{* * *} \\
(0.002)\end{array}$ \\
\hline \multirow{10}{*}{ Service utilized } & Email & $\begin{array}{c}-0.023^{* * *} \\
(0.001)\end{array}$ & $\begin{array}{c}-0.027^{* * *} \\
(0.001)\end{array}$ & $\begin{array}{c}-0.026^{* * *} \\
(0.001)\end{array}$ & $\begin{array}{l}0.046^{* * *} \\
(0.001)\end{array}$ & $\begin{array}{l}0.050^{* * * *} \\
(0.001)\end{array}$ & $\begin{array}{l}0.050^{* * *} \\
(0.001)\end{array}$ \\
\hline & Customer service call & $0.003^{* * *}$ & -0.003 & $-0.004^{*}$ & $0.041^{* * *}$ & $0.038^{* * *}$ & $0.038^{* * * *}$ \\
\hline & Web & $\begin{array}{c}(0.001) \\
-0.006^{* * *}\end{array}$ & $\begin{array}{l}(0.002) \\
-0.003^{* *}\end{array}$ & $\begin{array}{l}(0.002) \\
-0.002^{* *}\end{array}$ & $\begin{array}{l}(0.001) \\
0.028^{* * *}\end{array}$ & $\begin{array}{l}(0.003) \\
0.015^{* * *}\end{array}$ & $\begin{array}{l}(0.003) \\
0.015^{* * *}\end{array}$ \\
\hline & & $(0.001)$ & $(0.001)$ & $(0.001)$ & $(0.001)$ & $(0.002)$ & $(0.002)$ \\
\hline & Alerts & $\begin{array}{l}0.003^{* * * *} \\
(0.001)\end{array}$ & $\begin{array}{l}0.002^{*} \\
(0.001)\end{array}$ & $\begin{array}{c}0.001 \\
(0.001)\end{array}$ & $\begin{array}{l}-0.001 \\
(0.001) \\
\end{array}$ & $\begin{array}{l}0.007^{* * * *} \\
(0.001)\end{array}$ & $\begin{array}{l}0.007^{* * *} \\
(0.001)\end{array}$ \\
\hline & $\begin{array}{l}\text { Average value of ATM per } \\
\text { month }\end{array}$ & $\begin{array}{l}0.204^{* * * *} \\
(0.002)\end{array}$ & $\begin{array}{l}0.207^{* * *} \\
(0.003)\end{array}$ & $\begin{array}{l}0.205^{* * * *} \\
(0.002)\end{array}$ & $\begin{array}{c}-0.267^{* * * *} \\
(0.001)\end{array}$ & $\begin{array}{c}-0.269^{* * * *} \\
(0.003)\end{array}$ & $\begin{array}{c}-0.271^{* * *} \\
(0.003)\end{array}$ \\
\hline & Constant & $\begin{array}{l}0.309^{* * *} \\
(0.002)\end{array}$ & $\begin{array}{l}0.320^{* * *} \\
(0.003)\end{array}$ & $\begin{array}{l}0.158^{* * *} \\
(0.057)\end{array}$ & $\begin{array}{l}0.337^{* * *} \\
(0.002)\end{array}$ & $\begin{array}{l}0.307^{* * *} \\
(0.005)\end{array}$ & $\begin{array}{l}0.221^{* * *} \\
(0.064)\end{array}$ \\
\hline & Controls? & no & no & yes & no & no & yes \\
\hline & Observations & $2,985,337$ & 625,327 & 625,327 & $2,985,337$ & 625,327 & 625,327 \\
\hline & Adjusted R-squared & 0.075 & 0.087 & 0.089 & 0.113 & 0.119 & 0.120 \\
\hline
\end{tabular}

Notes: Standard errors are shown in parentheses. All variables are dummy. The vector of controls includes zip-code level demographic characteristics.

$* * *, * *, *$ Significant at the $0.01,0.05$, and 0.10 level, respectively. 
Table 4.10a: Results for Shares of PIN and Signature Card-Not-Present Transactions: Coefficients for Account Characteristics (cont.)

Share in Value

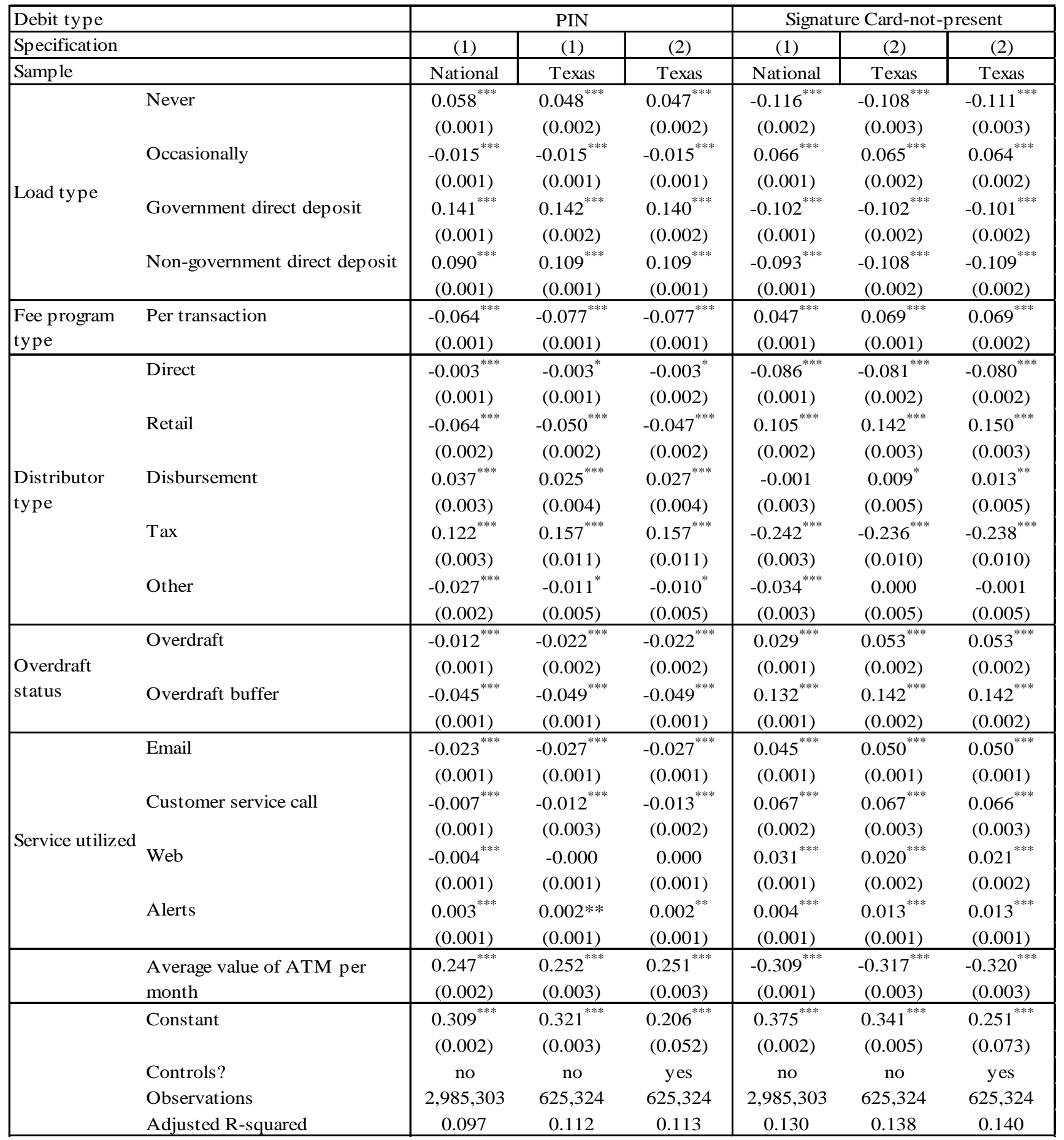

Notes: Standard errors are shown in parentheses. All variables are dummy. The vector of controls includes zip-code level demographic characteristics.

$* * *, * *, *$ Significant at the $0.01,0.05$, and 0.10 level, respectively. 
Table 4.10b: Results for Shares of PIN and Signature Card-Not-Present Transactions: Coefficients for Zip-code Level Demographic Characteristics

\begin{tabular}{|c|c|c|c|c|c|c|c|}
\hline \multicolumn{8}{|c|}{ Share in Volume } \\
\hline \multirow{2}{*}{\multicolumn{2}{|c|}{ Female }} & PIN & Sig CNP & & & PIN & Sig CNP \\
\hline & & $\begin{array}{c}-0.023 \\
(0.050) \\
\end{array}$ & $\begin{array}{c}0.046 \\
(0.051)\end{array}$ & \multirow{6}{*}{ Education } & Less than 9th grade & $\begin{array}{l}0.074^{* *} \\
(0.036)\end{array}$ & $\begin{array}{l}0.202^{* * *} \\
(0.042)\end{array}$ \\
\hline \multirow{6}{*}{ Race } & Black & $\begin{array}{l}-0.002 \\
(0.010)\end{array}$ & $\begin{array}{l}0.027^{* * *} \\
(0.010)\end{array}$ & & Less than 12 th grade & $\begin{array}{l}0.117^{* *} \\
(0.053)\end{array}$ & $\begin{array}{l}0.210^{* * *} \\
(0.052)\end{array}$ \\
\hline & American Indian & $\begin{array}{c}-0.458^{* * *} \\
(0.165)\end{array}$ & $\begin{array}{l}0.403^{* *} \\
(0.173)\end{array}$ & & Some college & $\begin{array}{c}0.067 \\
(0.046)\end{array}$ & $\begin{array}{c}-0.005 \\
(0.048)\end{array}$ \\
\hline & Asian & $\begin{array}{c}-0.065^{* * *} \\
(0.022)\end{array}$ & $\begin{array}{c}0.002 \\
(0.024)\end{array}$ & & Associate's degree & $\begin{array}{l}-0.010 \\
(0.068)\end{array}$ & $\begin{array}{c}0.123 \\
(0.078)\end{array}$ \\
\hline & Hawaiian & $\begin{array}{c}0.427 \\
(0.295)\end{array}$ & $\begin{array}{c}-0.301 \\
(0.326)\end{array}$ & & Bachelor's degree & $\begin{array}{l}0.108^{* * *} \\
(0.036)\end{array}$ & $\begin{array}{l}0.085^{* *} \\
(0.039)\end{array}$ \\
\hline & Other & $\begin{array}{l}-0.003 \\
(0.012)\end{array}$ & $\begin{array}{c}0.047^{* * *} \\
(0.018)\end{array}$ & & Graduate degree & $\begin{array}{c}0.070 \\
(0.044)\end{array}$ & $\begin{array}{c}0.068 \\
(0.047)\end{array}$ \\
\hline & Multiple race & $\begin{array}{l}0.214^{* *} \\
(0.087)\end{array}$ & $\begin{array}{c}-0.307^{* * *} \\
(0.088)\end{array}$ & \multirow{9}{*}{ Income } & Less than $\$ 10,000$ & $\begin{array}{c}0.010 \\
(0.045)\end{array}$ & $\begin{array}{l}-0.038 \\
(0.052)\end{array}$ \\
\hline & Hispanic & $\begin{array}{c}-0.057^{* * *} \\
(0.009)\end{array}$ & $\begin{array}{c}-0.034^{* * *} \\
(0.010)\end{array}$ & & $\$ 10,000-\$ 15,000$ & $\begin{array}{c}-0.033 \\
(0.063)\end{array}$ & $\begin{array}{c}0.059 \\
(0.076)\end{array}$ \\
\hline \multirow{6}{*}{ Age } & 15 and under & $\begin{array}{l}0.192^{* * *} \\
(0.067)\end{array}$ & $\begin{array}{c}-0.253^{* * *} \\
(0.064)\end{array}$ & & $\$ 15,000-\$ 25,000$ & $\begin{array}{c}0.001 \\
(0.055)\end{array}$ & $\begin{array}{l}-0.005 \\
(0.071)\end{array}$ \\
\hline & 15 to 24 & $\begin{array}{l}0.126^{* * *} \\
(0.049)\end{array}$ & $\begin{array}{l}-0.045 \\
(0.057)\end{array}$ & & $\$ 25,000-\$ 35,000$ & $\begin{array}{c}0.045 \\
(0.057)\end{array}$ & $\begin{array}{c}0.037 \\
(0.068)\end{array}$ \\
\hline & 35 to 44 & $\begin{array}{l}0.228^{* * *} \\
(0.081)\end{array}$ & $\begin{array}{c}-0.097 \\
(0.082)\end{array}$ & & $\$ 50,000-\$ 75,000$ & $\begin{array}{l}-0.060 \\
(0.052)\end{array}$ & $\begin{array}{c}0.085 \\
(0.065)\end{array}$ \\
\hline & 45 to 54 & $\begin{array}{l}0.172^{* *} \\
(0.069)\end{array}$ & $\begin{array}{l}-0.111 \\
(0.072)\end{array}$ & & $\$ 75,000-\$ 100,000$ & $\begin{array}{l}-0.048 \\
(0.053)\end{array}$ & $\begin{array}{c}0.060 \\
(0.068)\end{array}$ \\
\hline & 55 to 64 & $\begin{array}{c}0.079 \\
(0.074)\end{array}$ & $\begin{array}{l}-0.117^{*} \\
(0.070)\end{array}$ & & $\$ 100,000-\$ 150,000$ & $\begin{array}{l}-0.119^{* *} \\
(0.048)\end{array}$ & $\begin{array}{c}-0.008 \\
(0.059)\end{array}$ \\
\hline & 65 and over & $\begin{array}{c}0.028 \\
(0.069) \\
\end{array}$ & $\begin{array}{c}-0.214^{* * *} \\
(0.072)\end{array}$ & & $\$ 150,000-\$ 200,000$ & $\begin{array}{l}-0.146^{*} \\
(0.080)\end{array}$ & $\begin{array}{c}-0.004 \\
(0.103)\end{array}$ \\
\hline \multirow{4}{*}{$\begin{array}{c}\text { Marital } \\
\text { status }\end{array}$} & Married & $\begin{array}{l}0.070^{* *} \\
(0.034)\end{array}$ & $\begin{array}{l}0.113^{* * *} \\
(0.039)\end{array}$ & & More than $\$ 200,000$ & $\begin{array}{c}-0.186^{* * *} \\
(0.063)\end{array}$ & $\begin{array}{c}0.137^{*} \\
(0.070) \\
\end{array}$ \\
\hline & Widowed & $\begin{array}{l}0.169^{*} \\
(0.098)\end{array}$ & $\begin{array}{c}0.215^{*} \\
(0.121)\end{array}$ & \multirow{2}{*}{$\begin{array}{c}\text { Crime } \\
\text { incidents } \\
\text { per } 10,000 \\
\text { residents }\end{array}$} & Violent & $\begin{array}{c}-0.001 \\
(0.008)\end{array}$ & $\begin{array}{c}-0.012 \\
(0.009)\end{array}$ \\
\hline & Divorced & $\begin{array}{c}0.000 \\
(0.067)\end{array}$ & $\begin{array}{l}0.220^{* * *} \\
(0.073)\end{array}$ & & Property & $\begin{array}{c}0.000 \\
(0.001) \\
\end{array}$ & $\begin{array}{l}0.003^{* *} \\
(0.001)\end{array}$ \\
\hline & Separated & $\begin{array}{c}0.148 \\
(0.118) \\
\end{array}$ & $\begin{array}{c}0.057 \\
(0.143) \\
\end{array}$ & & $\begin{array}{l}\text { Observations } \\
\text { Adjusted R-squared }\end{array}$ & $\begin{array}{c}625,327 \\
0.089 \\
\end{array}$ & $\begin{array}{c}625,327 \\
0.120 \\
\end{array}$ \\
\hline
\end{tabular}

Notes: Standard errors are shown in parentheses. Crime incidents per 10,000 residents is continuous, and the other variables are dummy. Default race is White. Default age bracket is 25-34. Default education is High School. Default income bracket is $\$ 35,000-\$ 50,000$.

$* * *, * *, *$ Significant at the $0.01,0.05$, and 0.10 level, respectively.

Sources: The author's calculations using 2011 American Community Survey (sex, race, ethnicity, age, education, income, and marital status), 2010 FBI Uniform Crime Report (violent and property crime), and NetSpend. 
Table 4.10b: Results for Shares of PIN and Signature Card-Not-Present Transactions: Coefficients for Zip-code Level Demographic Characteristics (cont.)

Share in Value

\begin{tabular}{|c|c|c|c|c|c|c|c|}
\hline & & & & & \\
\hline & & \multirow{2}{*}{\multicolumn{2}{|c|}{\begin{tabular}{c|c} 
PIN & Sig CNP \\
0.000 & 0.046 \\
$(0.048)$ & $(0.061)$ \\
\end{tabular}}} & & & PIN & Sig CNP \\
\hline & Female & & & \multirow{7}{*}{ Education } & Less than 9th grade & $\begin{array}{l}-0.009 \\
(0.033)\end{array}$ & $\begin{array}{l}0.249^{* * *} \\
(0.048)\end{array}$ \\
\hline \multirow{7}{*}{ Race } & Black & $\begin{array}{l}-0.018^{* *} \\
(0.009)\end{array}$ & $\begin{array}{l}0.035^{* * *} \\
(0.012)\end{array}$ & & Less than 12 th grade & $\begin{array}{c}0.068 \\
(0.049)\end{array}$ & $\begin{array}{l}0.221^{* * *} \\
(0.063)\end{array}$ \\
\hline & American Indian & $-0.407^{* * *}$ & 0.343 & & Some college & 0.036 & 0.014 \\
\hline & Asian & $\begin{array}{l}(0.153) \\
-0.030\end{array}$ & -0.001 & & \multirow{2}{*}{ Associate's degree } & $\begin{array}{l}(0.043) \\
-0.002\end{array}$ & 0.095 \\
\hline & & $(0.020)$ & $(0.027)$ & & & $(0.066)$ & $(0.092)$ \\
\hline & Hawaiian & $\begin{array}{c}0.382 \\
(0.266)\end{array}$ & $\begin{array}{l}-0.459 \\
(0.442)\end{array}$ & & Bachelor's degree & $\begin{array}{l}0.084^{* *} \\
(0.034)\end{array}$ & $\begin{array}{l}0.098^{* *} \\
(0.046)\end{array}$ \\
\hline & Other & $\begin{array}{c}0.007 \\
(0.013)\end{array}$ & $\begin{array}{l}0.034^{*} \\
(0.020)\end{array}$ & & Graduate degree & $\begin{array}{c}0.042 \\
(0.040)\end{array}$ & $\begin{array}{c}0.044 \\
(0.056)\end{array}$ \\
\hline & Multiple race & $\begin{array}{l}0.203^{* *} \\
(0.080)\end{array}$ & $\begin{array}{c}-0.321^{* * *} \\
(0.103)\end{array}$ & \multirow{9}{*}{ Income } & Less than $\$ 10,000$ & $\begin{array}{c}0.037 \\
(0.040)\end{array}$ & $\begin{array}{l}-0.108^{*} \\
(0.059)\end{array}$ \\
\hline & Hispanic & $\begin{array}{c}-0.033^{* * *} \\
(0.008)\end{array}$ & $\begin{array}{c}-0.058^{* * *} \\
(0.012) \\
\end{array}$ & & $\$ 10,000-\$ 15,000$ & $\begin{array}{l}-0.042 \\
(0.059)\end{array}$ & $\begin{array}{c}0.027 \\
(0.090)\end{array}$ \\
\hline \multirow{6}{*}{ Age } & 15 and under & $\begin{array}{l}0.203^{* * *} \\
(0.063)\end{array}$ & $\begin{array}{c}-0.238^{* * *} \\
(0.076)\end{array}$ & & $\$ 15,000-\$ 25,000$ & $\begin{array}{c}0.027 \\
(0.052)\end{array}$ & $\begin{array}{l}-0.039 \\
(0.085)\end{array}$ \\
\hline & 15 to 24 & $\begin{array}{l}0.084^{*} \\
(0.047)\end{array}$ & $\begin{array}{c}0.005 \\
(0.067)\end{array}$ & & $\$ 25,000-\$ 35,000$ & $\begin{array}{c}0.037 \\
(0.054)\end{array}$ & $\begin{array}{c}0.019 \\
(0.078)\end{array}$ \\
\hline & 35 to 44 & $\begin{array}{l}0.212^{* * *} \\
(0.078)\end{array}$ & $\begin{array}{c}-0.094 \\
(0.102)\end{array}$ & & $\$ 50,000-\$ 75,000$ & $\begin{array}{c}-0.078 \\
(0.050)\end{array}$ & $\begin{array}{c}0.094 \\
(0.078)\end{array}$ \\
\hline & 45 to 54 & $\begin{array}{l}0.156^{* *} \\
(0.064)\end{array}$ & $\begin{array}{l}-0.138 \\
(0.085)\end{array}$ & & $\$ 75,000-\$ 100,000$ & $\begin{array}{l}-0.047 \\
(0.050)\end{array}$ & $\begin{array}{c}0.036 \\
(0.081)\end{array}$ \\
\hline & 55 to 64 & $\begin{array}{c}0.128^{*} \\
(0.066)\end{array}$ & $\begin{array}{c}-0.128 \\
(0.082)\end{array}$ & & $\$ 100,000-\$ 150,000$ & $\begin{array}{l}-0.097^{* *} \\
(0.045)\end{array}$ & $\begin{array}{c}-0.027 \\
(0.069)\end{array}$ \\
\hline & 65 and over & $\begin{array}{c}0.020 \\
(0.068) \\
\end{array}$ & $\begin{array}{c}-0.208^{* *} \\
(0.089)\end{array}$ & & $\$ 150,000-\$ 200,000$ & $\begin{array}{l}-0.060 \\
(0.074)\end{array}$ & $\begin{array}{c}-0.061 \\
(0.123)\end{array}$ \\
\hline \multirow{4}{*}{$\begin{array}{c}\text { Marital } \\
\text { status }\end{array}$} & Married & $\begin{array}{c}-0.005 \\
(0.030)\end{array}$ & $\begin{array}{l}0.139^{* * *} \\
(0.045)\end{array}$ & & More than $\$ 200,000$ & $\begin{array}{c}-0.181^{* * *} \\
(0.062)\end{array}$ & $\begin{array}{c}0.115 \\
(0.082)\end{array}$ \\
\hline & Widowed & $\begin{array}{c}0.057 \\
(0.096)\end{array}$ & $\begin{array}{l}0.309^{* *} \\
(0.146)\end{array}$ & \multirow{2}{*}{$\begin{array}{c}\text { Crime } \\
\text { incidents } \\
\text { per } 10,000 \\
\text { residents }\end{array}$} & Violent & $\begin{array}{c}0.002 \\
(0.008)\end{array}$ & $\begin{array}{l}-0.009 \\
(0.011)\end{array}$ \\
\hline & Divorced & $\begin{array}{l}-0.045 \\
(0.061)\end{array}$ & $\begin{array}{l}0.276^{* * *} \\
(0.083)\end{array}$ & & Property & $\begin{array}{c}0.001 \\
(0.001)\end{array}$ & $\begin{array}{c}0.001 \\
(0.002) \\
\end{array}$ \\
\hline & Separated & $\begin{array}{c}0.080 \\
(0.108)\end{array}$ & $\begin{array}{c}0.120 \\
(0.177)\end{array}$ & & $\begin{array}{l}\text { Observations } \\
\text { Adjusted R-squared }\end{array}$ & $\begin{array}{c}625,324 \\
0.113\end{array}$ & $\begin{array}{c}625,324 \\
0.140 \\
\end{array}$ \\
\hline
\end{tabular}

Notes: Standard errors are shown in parentheses. Crime incidents per 10,000 residents is continuous, and the other variables are dummy. Default race is White. Default age bracket is 25-34. Default education is High School. Default income bracket is $\$ 35,000-\$ 50,000$.

$* * *, * *$ * Significant at the $0.01,0.05$, and 0.10 level, respectively.

Sources: The author's calculations using 2011 American Community Survey (sex, race, ethnicity, age, education, income, and marital status), 2010 FBI Uniform Crime Report (violent and property crime), and NetSpend. 
Table 4.11: Cash Withdrawals versus Purchase Transactions

\begin{tabular}{|l|c|c|c|}
\hline \multirow{2}{*}{} & \multicolumn{2}{|c|}{ Transaction share (\%) } & Average \\
\cline { 2 - 3 } & Volume & Value & ticket \\
\hline Cash withdrawals $^{1}$ & 13.0 & 33.8 & $\$ 128.83$ \\
\hline Purchase transactions $^{2}$ & 87.0 & 66.2 & $\$ 37.51$ \\
\hline
\end{tabular}

${ }^{1}$ : Include ATM cash withdrawals and over-the-counter cash advances. The share of ATM withdrawals in cash withdrawals is 98 percent in volume and 92 percent in value.

2: Cash back at the point of sale is also included.

Table 4.12: Distribution of Purchase Transactions

\begin{tabular}{|l|c|c|c|}
\hline \multirow{2}{*}{ Total } & \multicolumn{2}{|c|}{ Transaction share (\%) } & Average \\
\cline { 2 - 3 } & Volume & Value & ticket \\
\hline PIN & $\mathbf{1 0 0}$ & $\mathbf{1 0 0}$ & $\mathbf{\$ 3 7 . 5 1}$ \\
\hline Purchase-only & $\mathbf{3 5 . 4}$ & $\mathbf{4 2 . 4}$ & $\mathbf{\$ 4 4 . 9 7}$ \\
\hline Purchase with cash back & 29.1 & 27.9 & $\$ 35.95$ \\
\hline PIN-less bill payments & 3.9 & 6.9 & $\$ 66.58$ \\
\hline Signature & 2.4 & 7.6 & $\$ 119.73$ \\
\hline Card-present & $\mathbf{6 4 . 6}$ & $\mathbf{5 7 . 6}$ & $\mathbf{\$ 3 3 . 4 2}$ \\
\hline Card-not-present & 42.5 & 22.9 & $\$ 20.25$ \\
\hline
\end{tabular}

Table 4.13a: Top Merchant Categories in Transaction Volume

\begin{tabular}{|c|c|c|c|c|}
\hline \multirow{2}{*}{ Rank } & \multirow{2}{*}{ Merchant category } & \multicolumn{2}{|c|}{ Transaction share (\%) } & \multirow{2}{*}{$\begin{array}{c}\text { Average } \\
\text { ticket }\end{array}$} \\
\hline & & Volume & Value & \\
\hline 1 & Gas stations & 18.8 & 8.0 & $\$ 16.02$ \\
\hline 2 & Fast food restaurants & 14.8 & 3.7 & $\$ 9.34$ \\
\hline 3 & Grocery stores & 13.7 & 19.2 & $\$ 52.52$ \\
\hline 4 & Restaurants & 5.9 & 3.6 & $\$ 22.55$ \\
\hline 5 & Discount stores & 3.7 & 3.4 & $\$ 35.26$ \\
\hline 6 & Telecommunications & 3.4 & 6.5 & $\$ 70.87$ \\
\hline 7 & Drug stores & 3.0 & 1.7 & $\$ 21.53$ \\
\hline 8 & Miscellaneous food stores & 2.3 & 0.9 & $\$ 15.64$ \\
\hline 9 & Clothing stores & 2.0 & 2.6 & $\$ 48.31$ \\
\hline 10 & Video/DVD rental stores & 1.8 & 0.3 & $\$ 6.13$ \\
\hline
\end{tabular}

Table 4.13b: Top Merchant Categories in Transaction Value

\begin{tabular}{|c|l|c|c|c|}
\hline \multirow{2}{*}{ Rank } & \multirow{2}{*}{ Merchant category } & \multicolumn{2}{|c|}{ Transaction share (\%) } & \multirow{2}{*}{$\begin{array}{c}\text { Average } \\
\text { ticket }\end{array}$} \\
\cline { 3 - 4 } & & Volume & Value & \\
\hline 1 & Grocery stores & 13.7 & 19.2 & $\$ 52.52$ \\
\hline 2 & Gas stations & 18.8 & 8.0 & $\$ 16.02$ \\
\hline 3 & Telecommunications & 3.4 & 6.5 & $\$ 70.87$ \\
\hline 4 & Cable & 1.7 & 5.0 & $\$ 112.03$ \\
\hline 5 & Utilities & 1.6 & 4.9 & $\$ 112.20$ \\
\hline 6 & Fast food restaurants & 14.8 & 3.7 & $\$ 9.34$ \\
\hline 7 & Restaurants & 5.9 & 3.6 & $\$ 22.55$ \\
\hline 8 & Discount stores & 3.7 & 3.4 & $\$ 35.26$ \\
\hline 9 & Insurance & 1.0 & 3.1 & $\$ 113.36$ \\
\hline 10 & Auto dealers & 0.5 & 2.8 & $\$ 225.76$ \\
\hline
\end{tabular}


Table 4.14: Top Merchant Categories for Five Types of Transactions

\begin{tabular}{|c|c|c|c|c|}
\hline \multicolumn{5}{|c|}{ PIN Purchase-only } \\
\hline \multirow{2}{*}{ Rank } & \multicolumn{2}{|c|}{ In Volume } & \multicolumn{2}{|l|}{ In Value } \\
\hline & Merchant category & Share & Merchant category & Share \\
\hline 1 & Grocery stores & 34.8 & Grocery stores & 51.0 \\
\hline 2 & Gas stations & 25.7 & Discount stores & 8.9 \\
\hline 3 & Discount stores & 10.2 & Gas stations & 8.9 \\
\hline 4 & Drug stores & 6.9 & Drug stores & 3.9 \\
\hline 5 & Miscellaneous food stores & 2.7 & Postal services & 3.4 \\
\hline \multicolumn{5}{|c|}{ PIN Purchase with Cash Back } \\
\hline \multirow{2}{*}{ Rank } & \multicolumn{2}{|c|}{ In Volume } & \multicolumn{2}{|l|}{ In Value } \\
\hline & Merchant category & Share & Merchant category & Share \\
\hline 1 & Grocery stores & 50.4 & Grocery stores & 59.3 \\
\hline 2 & Drug stores & 17.1 & U.S. Postal Service & 16.4 \\
\hline 3 & Gas stations & 15.4 & Drug stores & 8.1 \\
\hline 4 & Discount stores & 7.7 & Discount stores & 5.4 \\
\hline 5 & U.S. Postal Service & 2.6 & Gas stations & 5.3 \\
\hline \multicolumn{5}{|c|}{ PIN-less Bill Payments } \\
\hline \multirow{2}{*}{ Rank } & \multicolumn{2}{|l|}{$\begin{array}{r}\text { In Volume } \\
\end{array}$} & \multicolumn{2}{|l|}{$\begin{array}{r}\text { In Value } \\
\end{array}$} \\
\hline & Merchant category & Share & Merchant category & Share \\
\hline 1 & Telecommunications & 43.2 & Utilities & 32.9 \\
\hline 2 & Utilities & 27.2 & Telecommunications & 27.7 \\
\hline 3 & Cable & 13.9 & Cable & 16.3 \\
\hline 4 & Insurance & 8.0 & Insurance & 9.7 \\
\hline 5 & Auto dealers & 1.9 & Auto dealers & 4.3 \\
\hline \multicolumn{5}{|c|}{$\begin{array}{l}\text { Signature Card-Present } \\
\end{array}$} \\
\hline \multirow{2}{*}{ Rank } & \multicolumn{2}{|c|}{ In Volume } & \multicolumn{2}{|l|}{ In Value } \\
\hline & Merchant category & Share & Merchant category & Share \\
\hline 1 & Fast food restaurants & 33.0 & Gas stations & 20.9 \\
\hline 2 & Gas stations & 23.7 & Fast food restaurants & 14.6 \\
\hline 3 & Restaurants & 12.4 & Restaurants & 13.7 \\
\hline 4 & Grocery stores & 5.1 & Grocery stores & 6.0 \\
\hline 5 & Miscellaneous food stores & 3.0 & Barber and beauty shops & 1.9 \\
\hline \multicolumn{5}{|c|}{ Signature Card-Not-Present } \\
\hline \multirow{2}{*}{ Rank } & \multicolumn{2}{|c|}{ In Volume } & \multicolumn{2}{|l|}{$\begin{array}{r}\text { In Value } \\
\end{array}$} \\
\hline & Merchant category & Share & Merchant category & Share \\
\hline 1 & Telecommunications & 9.6 & Cable & 10.8 \\
\hline 2 & Cable & 6.0 & Telecommunications & 10.8 \\
\hline 3 & Advertising services & 5.7 & Utilities & 6.5 \\
\hline 4 & Record shops & 5.6 & Insurance & 6.4 \\
\hline 5 & $\begin{array}{l}\text { Direct marketing: } \\
\text { continuity/subscription }\end{array}$ & 5.5 & Equipment rental and leasing & 3.6 \\
\hline
\end{tabular}


Table 5.1: Monthly Cardholder Fees Received by Card Issuers

\begin{tabular}{|l|c|c|c|c|c|c|}
\hline \multirow{2}{*}{} & \multirow{2}{*}{ Mean } & \multicolumn{5}{|c|}{ Percentile } \\
\cline { 3 - 7 } & & $10^{\text {th }}$ & $30^{\text {th }}$ & $50^{\text {th }}($ Median $)$ & $70^{\text {th }}$ & $90^{\text {th }}$ \\
\hline Volume & 6.8 & 1.0 & 2.3 & 4.0 & 7.1 & 15.7 \\
\hline Value & $\$ 11.00$ & $\$ 1.35$ & $\$ 3.33$ & $\$ 6.37$ & $\$ 11.98$ & $\$ 26.44$ \\
\hline
\end{tabular}




\section{Chart 5.1: Average Fee Composition}

\section{In Volume}

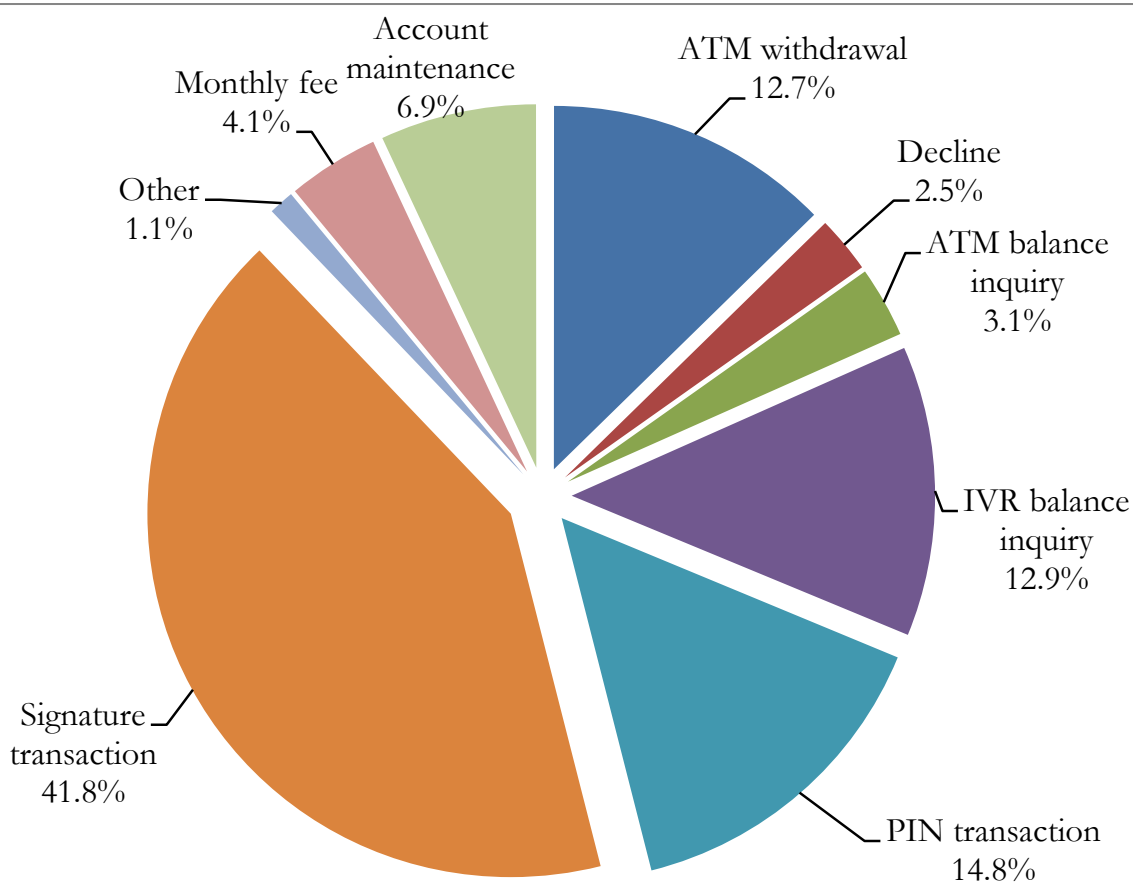

\section{In Value}

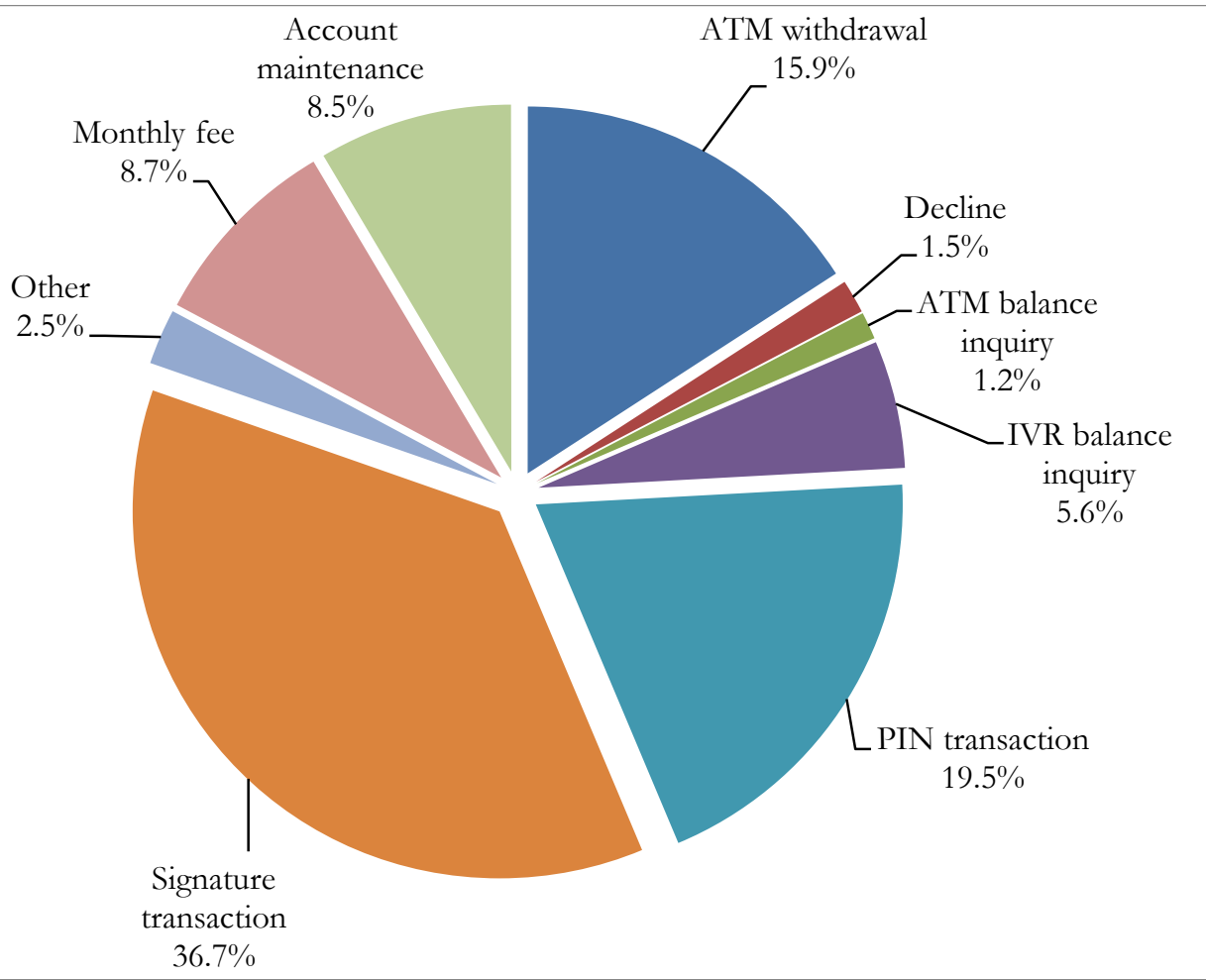


Table 5.2: Average and Relative Cardholder Fees per Month

\begin{tabular}{|c|c|c|c|c|c|}
\hline \multirow{2}{*}{\multicolumn{2}{|c|}{ Account characteristics }} & \multicolumn{2}{|c|}{ Average fee } & \multicolumn{2}{|c|}{$\begin{array}{c}\text { Relative fee (fee per } \\
\text { debit transaction) }\end{array}$} \\
\hline & & Volume & Value & Volume $^{1}$ & Value $^{2}$ \\
\hline \multicolumn{2}{|l|}{ All } & 6.8 & $\$ 11.00$ & 1.3 & $\$ 1.94$ \\
\hline \multirow[t]{5}{*}{ Load type } & Never reload & 4.5 & $\$ 7.76$ & 1.6 & $\$ 2.61$ \\
\hline & Occasional reload & 2.4 & $\$ 3.63$ & 1.3 & $\$ 1.94$ \\
\hline & Periodic self-funded & 7.0 & $\$ 10.14$ & 1.4 & $\$ 1.91$ \\
\hline & Periodic government direct deposit & 10.5 & $\$ 18.23$ & 1.4 & $\$ 2.10$ \\
\hline & Periodic non-government direct deposit & 10.8 & $\$ 20.08$ & 0.8 & $\$ 1.28$ \\
\hline \multirow{2}{*}{$\begin{array}{l}\text { Fee program } \\
\text { type }\end{array}$} & Per transaction & 6.9 & $\$ 9.74$ & 1.5 & $\$ 2.09$ \\
\hline & Monthly & 6.6 & $\$ 15.18$ & 0.6 & $\$ 1.45$ \\
\hline \multirow{6}{*}{$\begin{array}{l}\text { Distributor } \\
\text { type }\end{array}$} & Check casher & 7.1 & $\$ 11.17$ & 1.4 & $\$ 1.98$ \\
\hline & Direct & 6.0 & $\$ 10.68$ & 1.1 & $\$ 1.60$ \\
\hline & Retail & 6.2 & $\$ 9.00$ & 1.3 & $\$ 1.93$ \\
\hline & Disbursement & 6.5 & $\$ 11.94$ & 1.4 & $\$ 2.75$ \\
\hline & Tax & 19.3 & $\$ 26.81$ & 1.6 & $\$ 2.45$ \\
\hline & Other & 5.4 & $\$ 9.73$ & 1.1 & $\$ 1.91$ \\
\hline \multirow{6}{*}{$\begin{array}{l}\text { Service } \\
\text { utilized }\end{array}$} & Alert & 7.8 & $\$ 13.24$ & 1.1 & $\$ 1.64$ \\
\hline & Email & 7.2 & $\$ 12.32$ & 1.1 & $\$ 1.71$ \\
\hline & Customer service call & 7.0 & $\$ 11.26$ & 1.3 & $\$ 1.92$ \\
\hline & Web & 7.5 & $\$ 12.61$ & 1.1 & $\$ 1.69$ \\
\hline & Overdraft & 10.9 & $\$ 27.24$ & 0.7 & $\$ 1.68$ \\
\hline & Overdraft buffer & 7.7 & $\$ 12.62$ & 1.0 & $\$ 1.47$ \\
\hline
\end{tabular}

${ }^{1}$ : Monthly fee volume is divided by monthly debit volume.

${ }^{2}$ : Monthly fee value is divided by monthly debit volume. 
Table 5.3a: Results for the Number and Value of Fees Relative to the Number of Debit Transactions: Coefficients for Account Characteristics

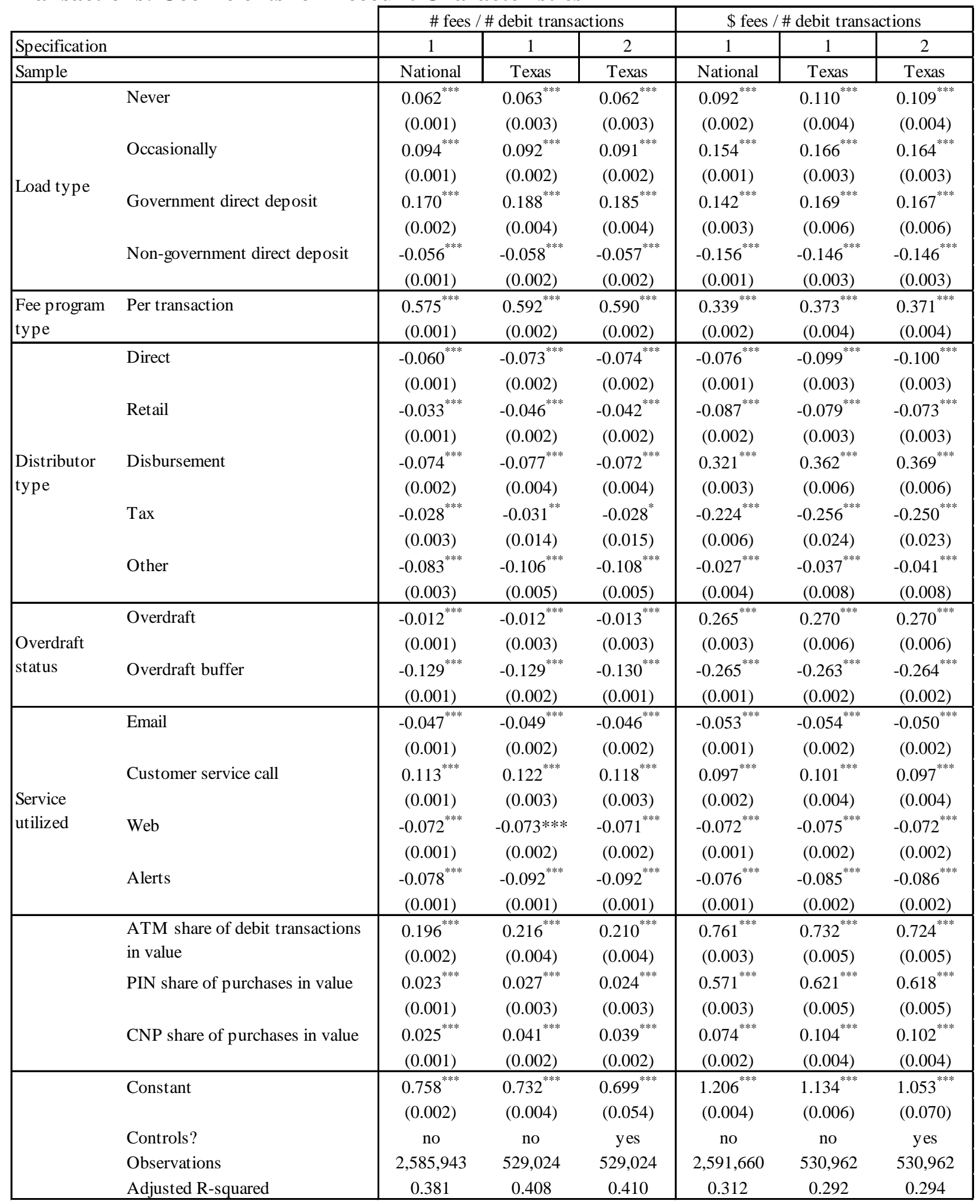

Notes: Standard errors are shown in parentheses. ATM share, PIN share, and CNP share are continuous, and the other variables are dummy. The vector of controls includes zip-code level demographic characteristics.

$* * *, * *, *$ Significant at the $0.01,0.05$, and 0.10 level, respectively. 
Table 5.3b: Results for the Number and Value of Fees Relative to the Number of Debit Transactions: Coefficients for Zip-code Level Demographic Characteristics

\begin{tabular}{|c|c|c|c|}
\hline & & \#/\# & $\$ / \#$ \\
\hline & Female & -0.056 & -0.051 \\
\hline \multirow{6}{*}{ Race } & Black & $\begin{array}{l}0.054^{* * * *} \\
(0.008)\end{array}$ & $\begin{array}{l}0.107^{* * *} \\
(0.012)\end{array}$ \\
\hline & American Indian & $\begin{array}{l}-0.081 \\
(0.171)\end{array}$ & $\begin{array}{l}-0.078 \\
(0.224)\end{array}$ \\
\hline & Asian & $\begin{array}{l}-0.010 \\
(0.024)\end{array}$ & $\begin{array}{l}-0.038 \\
(0.031)\end{array}$ \\
\hline & Hawaiian & $\begin{array}{c}0.076 \\
(0.202)\end{array}$ & $\begin{array}{c}0.141 \\
(0.291)\end{array}$ \\
\hline & Other & $\begin{array}{l}0.032^{* *} \\
(0.015)\end{array}$ & $\begin{array}{c}0.024 \\
(0.019)\end{array}$ \\
\hline & Multiple race & $\begin{array}{c}-0.112 \\
(0.074)\end{array}$ & $\begin{array}{l}-0.100 \\
(0.099)\end{array}$ \\
\hline & Hispanic & $\begin{array}{c}0.004 \\
(0.008)\end{array}$ & $\begin{array}{c}0.013 \\
(0.012)\end{array}$ \\
\hline \multirow{6}{*}{ Age } & 15 and under & $\begin{array}{c}0.055 \\
(0.057)\end{array}$ & $\begin{array}{l}-0.053 \\
(0.079)\end{array}$ \\
\hline & 15 to 24 & $\begin{array}{c}0.017 \\
(0.046)\end{array}$ & $\begin{array}{c}0.063 \\
(0.059)\end{array}$ \\
\hline & 35 to 44 & $\begin{array}{c}0.021 \\
(0.082)\end{array}$ & $\begin{array}{c}0.024 \\
(0.102)\end{array}$ \\
\hline & 45 to 54 & $\begin{array}{c}0.060 \\
(0.063)\end{array}$ & $\begin{array}{c}0.081 \\
(0.086)\end{array}$ \\
\hline & 55 to 64 & $\begin{array}{l}-0.053 \\
(0.064)\end{array}$ & $\begin{array}{l}-0.073 \\
(0.089)\end{array}$ \\
\hline & 65 and over & $\begin{array}{c}0.053 \\
(0.062)\end{array}$ & $\begin{array}{l}-0.066 \\
(0.088)\end{array}$ \\
\hline \multirow{4}{*}{$\begin{array}{c}\text { Marital } \\
\text { status }\end{array}$} & Married & $\begin{array}{c}0.021 \\
(0.033)\end{array}$ & $\begin{array}{l}0.127^{* * *} \\
(0.047)\end{array}$ \\
\hline & Widowed & $\begin{array}{l}0.185^{*} \\
(0.095)\end{array}$ & $\begin{array}{c}0.396^{* * * * *} \\
(0.128)\end{array}$ \\
\hline & Divorced & $\begin{array}{l}-0.039 \\
(0.064)\end{array}$ & $\begin{array}{l}-0.072 \\
(0.080)\end{array}$ \\
\hline & Separated & $\begin{array}{c}0.066 \\
(0.112)\end{array}$ & $\begin{array}{c}0.144 \\
(0.147)\end{array}$ \\
\hline
\end{tabular}

\begin{tabular}{|c|c|c|c|}
\hline & & \#/\# & \$/\# \\
\hline \multirow{11}{*}{ Education } & Less than 9th grade & 0.039 & $0.150^{* * *}$ \\
\hline & Less than 12th orade & $\begin{array}{c}(0.030) \\
0.049\end{array}$ & $\begin{array}{c}(0.043) \\
0.022\end{array}$ \\
\hline & Less tirall 12 til gidue & $(0.050)$ & $(0.065)$ \\
\hline & Some college & -0.004 & 0.013 \\
\hline & & $(0.035)$ & $(0.050)$ \\
\hline & Associate's degree & $0.193^{* * * *}$ & $0.146^{*}$ \\
\hline & & $(0.062)$ & $(0.088)$ \\
\hline & Bachelor's degree & -0.010 & -0.067 \\
\hline & & $(0.035)$ & $(0.047)$ \\
\hline & Graduate degree & $0.140^{* * *}$ & $0.271^{* * *}$ \\
\hline & & $(0.040)$ & $(0.052)$ \\
\hline \multirow{18}{*}{ Income } & Less than $\$ 10,000$ & 0.014 & -0.034 \\
\hline & & $(0.040)$ & (0.059) \\
\hline & $\$ 10,000-\$ 15,000$ & -0.033 & 0.013 \\
\hline & & $(0.057)$ & $(0.080)$ \\
\hline & $\$ 15,000-\$ 25,000$ & 0.059 & 0.017 \\
\hline & & $(0.045)$ & $(0.071)$ \\
\hline & $\$ 25,000-\$ 35,000$ & 0.048 & 0.044 \\
\hline & & $(0.050)$ & $(0.076)$ \\
\hline & $\$ 50,000-\$ 75,000$ & -0.040 & -0.035 \\
\hline & & $(0.047)$ & $(0.072)$ \\
\hline & $\$ 75,000-\$ 100,000$ & -0.070 & -0.088 \\
\hline & & $(0.048)$ & $(0.071)$ \\
\hline & $\$ 100,000-\$ 150,000$ & $-0.115^{* * *}$ & $-0.148^{* *}$ \\
\hline & & $(0.043)$ & $(0.064)$ \\
\hline & $\$ 150,000-\$ 200,000$ & 0.020 & 0.066 \\
\hline & & $(0.073)$ & $(0.118)$ \\
\hline & More than $\$ 200,000$ & $-0.107^{*}$ & -0.071 \\
\hline & & $(0.059)$ & $(0.079)$ \\
\hline \multirow{6}{*}{$\begin{array}{c}\text { Crime } \\
\text { incidents } \\
\text { per } 10,000 \\
\text { residents } \\
\end{array}$} & Violent & $0.023^{* * * *}$ & $0.041^{* * * *}$ \\
\hline & & $(0.007)$ & $(0.009)$ \\
\hline & Property & $-0.004^{* * *}$ & $-0.006^{* * *}$ \\
\hline & & $(0.001)$ & $(0.001)$ \\
\hline & Observations & 529,024 & 530,962 \\
\hline & Adjusted R-squared & 0.410 & 0.294 \\
\hline
\end{tabular}

Notes: Standard errors are shown in parentheses. Crime incidents per 10,000 residents is continuous, and the other variables are dummy. Default race is White. Default age bracket is 25-34. Default education is High School. Default income bracket is $\$ 35,000-$ $\$ 50,000$.

$* * *, * *, *$ Significant at the $0.01,0.05$, and 0.10 level, respectively.

Sources: The author's calculations using 2011 American Community Survey (sex, race, ethnicity, age, education, income, and marital status), 2010 FBI Uniform Crime Report (violent and property crime), and NetSpend. 
Table 5.4: Statistics on ATM Surcharges

\begin{tabular}{|l|l|c|c|}
\hline & & \multicolumn{2}{|c|}{ Assumption } \\
\hline & & 1 & 2 \\
\hline \multirow{3}{*}{ All withdrawals } & Mean surcharge value & $\$ 2.26$ & $\$ 2.33$ \\
\cline { 2 - 4 } & Median surcharge value & $\$ 2.50$ & $\$ 2.50$ \\
\cline { 2 - 4 } & Share of ATM withdrawals with zero surcharge & $7.2 \%$ & $6.8 \%$ \\
\cline { 2 - 4 } & Share of ATM withdrawals with surcharges $>=\$ 5$ & $0 \%$ & $1.1 \%$ \\
\hline \multirow{2}{*}{$\begin{array}{l}\text { Withdrawals with positive } \\
\text { surcharges }\end{array}$} & Mean surcharge value & $\$ 2.43$ & $\$ 2.50$ \\
\cline { 2 - 4 } & Median surcharge value & $\$ 2.50$ & $\$ 2.50$ \\
\hline
\end{tabular}

Notes: Assumption 1 assumes that ATMs dispense $\$ 5$ bills and thus no surcharges exceed $\$ 5$. Assumption 2 assumes that ATMs do not dispense $\$ 5$ bills. 
Table 6.1: Fraud Rate by Transaction Type

\begin{tabular}{|l|c|c|c|}
\hline \multirow{2}{*}{ Total } & \multicolumn{2}{|c|}{ Fraud rate (bps) } & Average \\
\cline { 2 - 3 } & In volume & In value & ticket \\
\hline Cash withdrawals & $\mathbf{5 . 9 3}$ & $\mathbf{9 . 6 0}$ & $\mathbf{\$ 7 9 . 8 5}$ \\
\hline ATM & $\mathbf{9 . 6 0}$ & $\mathbf{9 . 2 2}$ & $\mathbf{\$ 1 2 3 . 6 8}$ \\
\hline Over the counter & 9.71 & 9.93 & $\$ 123.31$ \\
\hline Purchase transactions & 3.44 & 1.02 & $\$ 185.05$ \\
\hline PIN & $\mathbf{5 . 3 9}$ & $\mathbf{9 . 8 0}$ & $\mathbf{\$ 6 8 . 2 3}$ \\
\hline Purchase-only & $\mathbf{2 . 5 4}$ & $\mathbf{3 . 8 3}$ & $\mathbf{\$ 6 7 . 9 0}$ \\
\hline Purchase with cash back & 2.10 & 3.47 & $\$ 59.37$ \\
\hline PIN-less bill payments & 4.08 & 3.91 & $\$ 63.79$ \\
\hline Signature & 5.30 & 5.06 & $\$ 114.38$ \\
\hline Card-present & $\mathbf{6 . 9 5}$ & $\mathbf{1 4 . 2 0}$ & $\mathbf{\$ 6 8 . 3 0}$ \\
\hline Card-not-present & 3.98 & 11.96 & $\$ 60.88$ \\
\hline
\end{tabular}


Table 6.2: Fraud Rate by Transaction Type and by Fraud Type

\begin{tabular}{|c|c|c|c|}
\hline \multicolumn{4}{|c|}{ ATM Withdrawals } \\
\hline & \multicolumn{2}{|c|}{ Fraud rate (bps) } & \multirow{2}{*}{$\begin{array}{c}\text { Average } \\
\text { ticket }\end{array}$} \\
\hline & In volume & In value & \\
\hline Counterfeit & 3.17 & 3.22 & $\$ 122.43$ \\
\hline Lost or stolen & 6.49 & 6.64 & $\$ 123.34$ \\
\hline Account takeover & 0.03 & 0.04 & $\$ 186.50$ \\
\hline Other unauthorized & 0.03 & 0.03 & $\$ 160.81$ \\
\hline \multicolumn{4}{|c|}{ Over the Counter Cash Advances } \\
\hline & \multicolumn{2}{|c|}{ Fraud rate (bps) } & \multirow{2}{*}{$\begin{array}{c}\text { Average } \\
\text { ticket }\end{array}$} \\
\hline & In volume & In value & \\
\hline Counterfeit & 1.25 & 0.27 & $\$ 135.25$ \\
\hline Lost or stolen & 2.19 & 0.75 & $\$ 213.51$ \\
\hline \multicolumn{4}{|c|}{ PIN Purchase-only } \\
\hline & \multicolumn{2}{|c|}{ Fraud rate (bps) } & \multirow{2}{*}{$\begin{array}{c}\text { Average } \\
\text { ticket }\end{array}$} \\
\hline & In volume & In value & \\
\hline Counterfeit & 0.61 & 1.24 & $\$ 72.89$ \\
\hline Lost or stolen & 1.48 & 2.22 & $\$ 54.09$ \\
\hline Other unauthorized & 0.01 & 0.01 & $\$ 26.20$ \\
\hline \multicolumn{4}{|c|}{ PIN Purchase with Cash Back } \\
\hline & \multicolumn{2}{|c|}{ Fraud rate (bps) } & \multirow{2}{*}{$\begin{array}{c}\text { Average } \\
\text { ticket }\end{array}$} \\
\hline & In volume & In value & \\
\hline Counterfeit & 1.04 & 0.77 & $\$ 49.22$ \\
\hline Lost or stolen & 3.02 & 3.11 & $\$ 68.56$ \\
\hline Account takeover & 0.02 & 0.03 & $\$ 101.71$ \\
\hline \multicolumn{4}{|c|}{ PIN-less Bill Payments } \\
\hline & \multicolumn{2}{|c|}{ Fraud rate (bps) } & \multirow{2}{*}{$\begin{array}{c}\text { Average } \\
\text { ticket }\end{array}$} \\
\hline & In volume & In value & \\
\hline Counterfeit & 4.21 & 4.26 & $\$ 121.33$ \\
\hline Lost or stolen & 0.83 & 0.68 & $\$ 97.26$ \\
\hline Other unauthorized & 0.26 & 0.12 & $\$ 56.30$ \\
\hline \multicolumn{4}{|c|}{ Signature Card-Present } \\
\hline & \multicolumn{2}{|c|}{ Fraud rate (bps) } & \multirow{2}{*}{$\begin{array}{c}\text { Average } \\
\text { ticket }\end{array}$} \\
\hline & In volume & In value & \\
\hline Counterfeit & 1.71 & 5.39 & $\$ 64.02$ \\
\hline Lost or stolen & 2.22 & 6.43 & $\$ 58.71$ \\
\hline Other unauthorized & 0.05 & 0.14 & $\$ 50.74$ \\
\hline \multicolumn{4}{|c|}{ Signature Card-Not-Present } \\
\hline & \multicolumn{2}{|c|}{ Fraud rate (bps) } & \multirow{2}{*}{$\begin{array}{c}\text { Average } \\
\text { ticket }\end{array}$} \\
\hline & In volume & In value & \\
\hline Counterfeit & 10.70 & 13.47 & $\$ 73.91$ \\
\hline Lost or stolen & 1.54 & 1.34 & $\$ 51.28$ \\
\hline Other unauthorized & 0.41 & 0.87 & $\$ 123.07$ \\
\hline
\end{tabular}


Table 6.3: Fraud Rates among Largest Merchant Categories

\begin{tabular}{|c|c|c|c|c|}
\hline \multirow{2}{*}{ Merchant category } & \multicolumn{2}{|c|}{ Fraud rate (bps) } & \multirow{2}{*}{$\begin{array}{c}\text { Signature card- } \\
\text { not-present share } \\
\text { in volume (\%) }\end{array}$} & \multirow{2}{*}{$\begin{array}{l}\text { PIN share in } \\
\text { volume (\%) }\end{array}$} \\
\hline & In volume & In value & & \\
\hline Direct marketing & 22.9 & 25.3 & 98.6 & 1.4 \\
\hline $\begin{array}{l}\text { Miscellaneous business } \\
\text { services }^{1}\end{array}$ & 20.4 & 15.6 & 90.2 & 3.3 \\
\hline $\begin{array}{l}\text { Miscellaneous professional } \\
\text { services }^{2}\end{array}$ & 9.7 & 15.5 & 98.0 & 0.6 \\
\hline Specialty retail stores $^{3}$ & 9.1 & 15.8 & 33.4 & 24.2 \\
\hline Cable & 8.8 & 18.2 & 79.8 & 19.8 \\
\hline Telecommunications & 8.5 & 9.1 & 61.9 & 34.0 \\
\hline Clothing stores & 8.0 & 18.1 & 11.9 & 56.1 \\
\hline $\begin{array}{l}\text { Miscellaneous and specialty } \\
\text { retail stores }\end{array}$ & 7.6 & 10.4 & 24.0 & 42.1 \\
\hline Gas stations & 4.0 & 8.0 & 1.4 & 45.1 \\
\hline Restaurants & 3.7 & 6.1 & 9.9 & 1.5 \\
\hline Discount stores & 3.5 & 8.1 & 1.6 & 92.4 \\
\hline Insurance & 3.3 & 3.5 & 77.7 & 20.0 \\
\hline Grocery stores & 3.2 & 5.8 & 0.3 & 83.9 \\
\hline Utilities & 3.0 & 3.5 & 57.7 & 40.7 \\
\hline Auto services & 2.9 & 3.5 & 13.5 & 36.4 \\
\hline Drug stores & 2.9 & 5.4 & 2.1 & 75.4 \\
\hline Fast food restaurants & 2.1 & 2.5 & 3.0 & 2.3 \\
\hline
\end{tabular}

${ }^{1}$ : Excludes advertising, computer-related, and equipment rental and leasing services.

${ }^{2}$ : Excludes legal and medical professions.

${ }^{3}:$ Merchant Category Code $=5733$, 5932-5937, 5944-5950, 5970-5973, 5977, 5992-5994, and 5996-5998.

${ }^{4}$ : Merchant Category Code $=5999$. 